\title{
DEVELOPING A HANDBOOK FOR CONSTRUCTION EQUTPMENT MANAGEMENT AND IMPLEMENTATION
}

\section{By}

RUSSELL V. SEIGNIOUS

A REPORT PRESENTED TO THE GRADUATE COMMITTEE OF THE DEPARTMENT OF CIVIL ENGINEERING IN PARTIAL FULFILIMENT OF THE REQUIREMENNTS FOR THE DEGREE OF MASTER OF ENGINEERING

UNIVERSITY OF FLORIDA

SUMMER 1999 


\section{Table of contents}

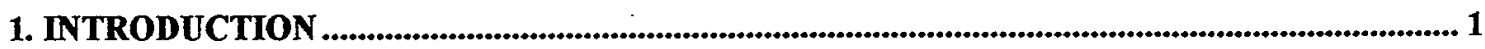

2. EQUTPMENT ECONOMICS

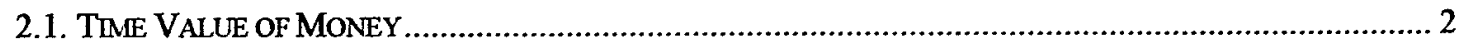

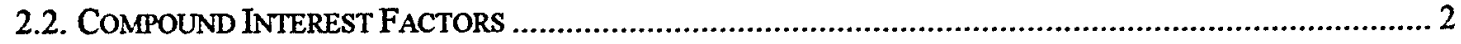

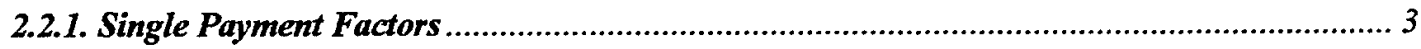

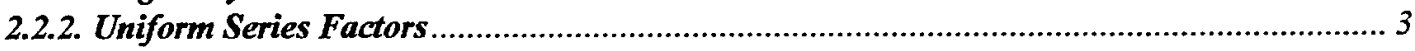

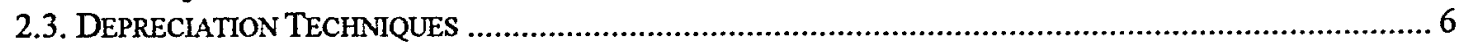

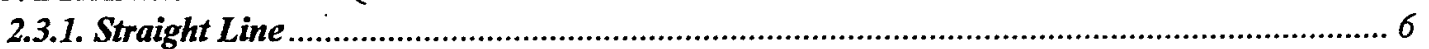

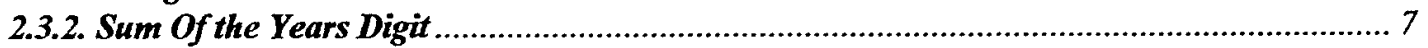

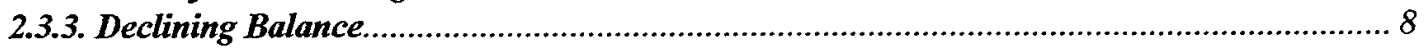

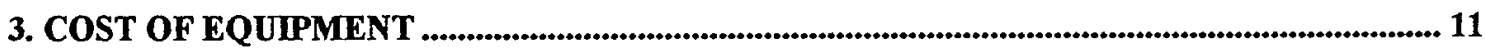

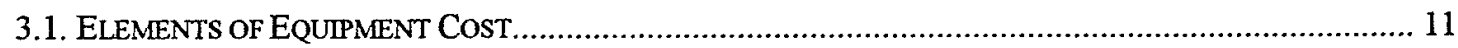

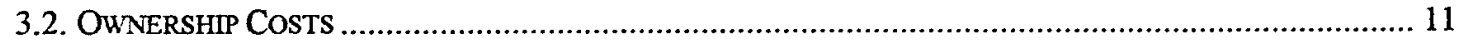

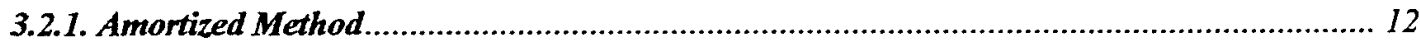

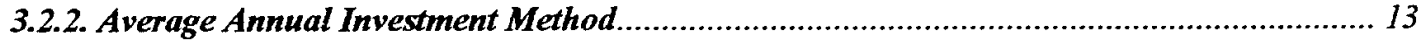

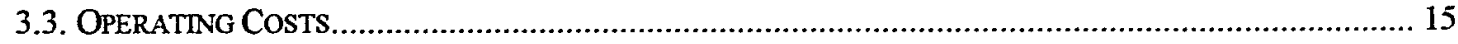

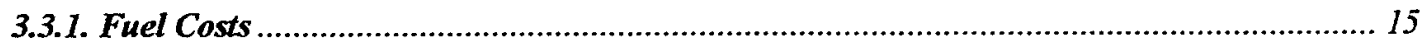

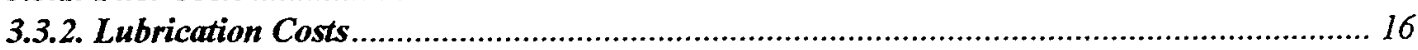

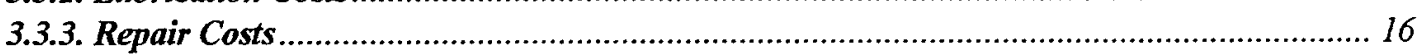

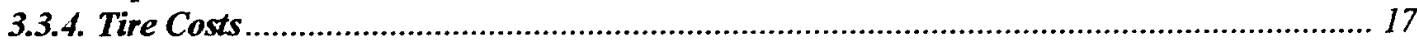

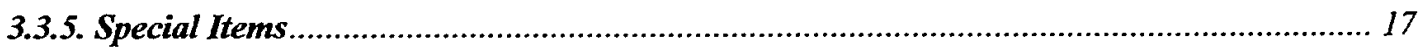

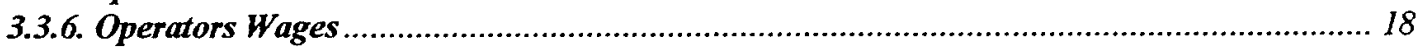

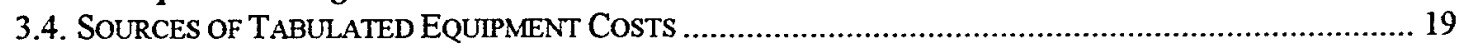

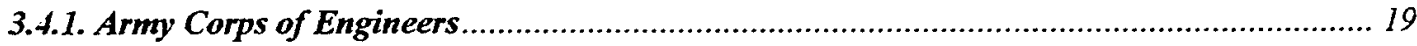

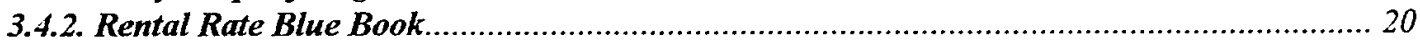

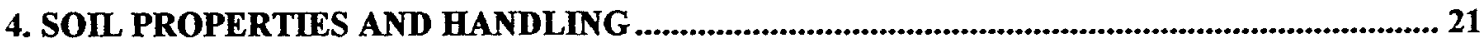

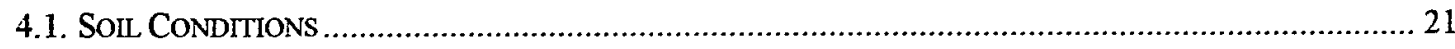

4.1.1. Bank Measure

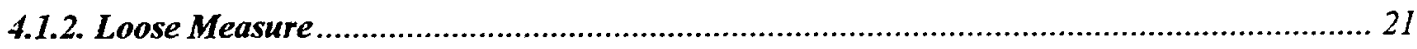

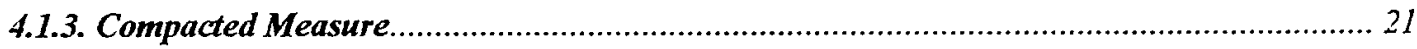

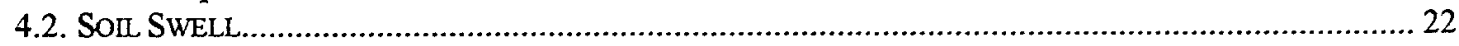

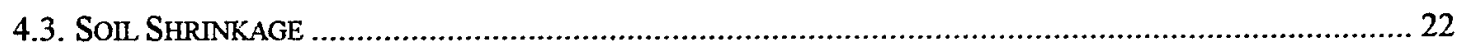

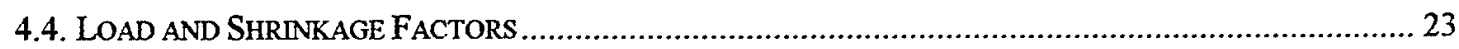

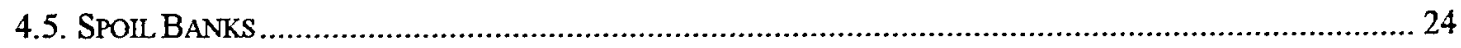

5. PRODUCTIVITY

6. EXCAVATING EQUIPMENT

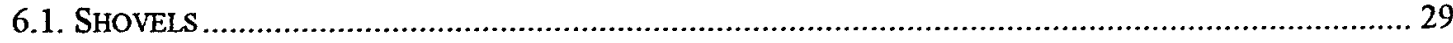

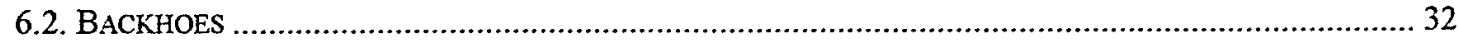

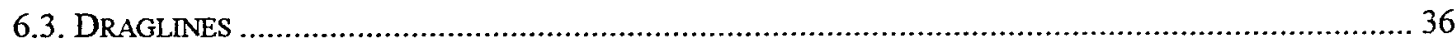

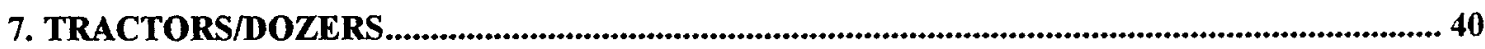

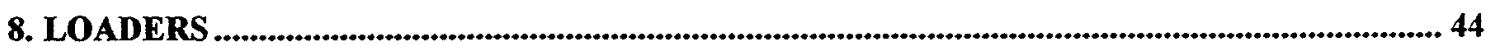

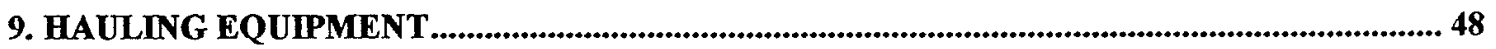




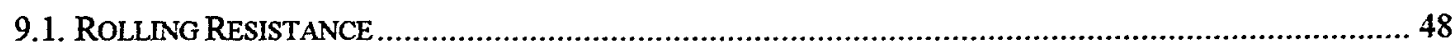

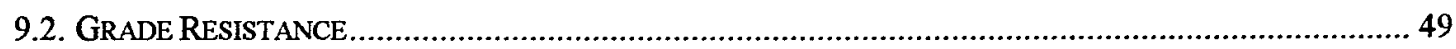

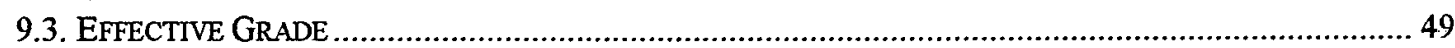

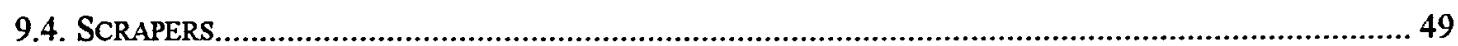

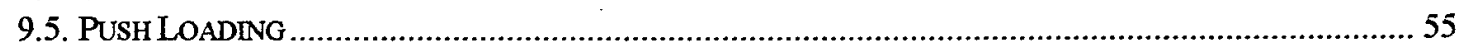

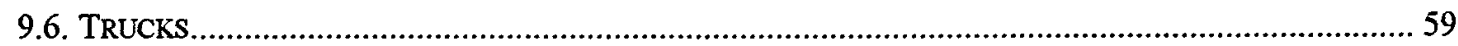

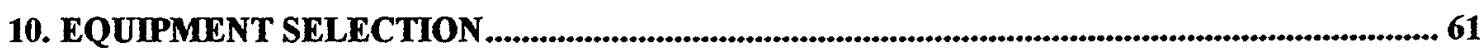

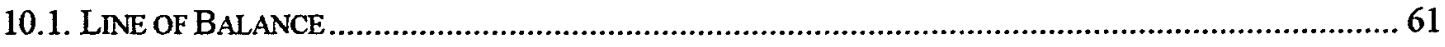

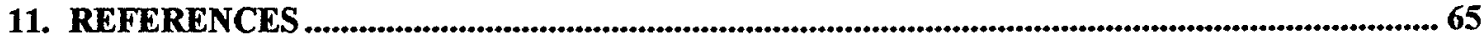

APPENDIX A - COMPOUND INTEREST TABLES ...................................................................66 


\section{Introduction}

Construction equipment may constitute one of the single largest long term capital investments for a contractor. This is particularly true for those contractors engaged primarily in horizontal construction. Regardless of the type of construction, the goal of successful construction management is to complete projects in accordance with plans and specifications, on time, within budget, and at the least possible cost. A crucial element in accomplishing the aforementioned goal is the effective management and implementation of construction equipment.

The fundamental goal of the equipment management process is to determine the best piece of equipment for a given job. Although this is not necessarily a complex notion, there are many factors to consider in making this determination. Most importantly, the equipment must pay for itself. In other words, the cost to own and operate the equipment must be less than what the equipment owner charges for its use. Today there exist many different types of equipment that can accomplish the same job. Thus, the equipment manager must typically consider more than one option.

Inefficient management of equipment can result in low production and/or idle equipment; either of which can impact project duration and cost. Therefore, it is important for contractors, construction managers, project managers, and any person directly responsible for equipment management to be familiar with the methods leading to selection of the appropriate equipment for a given job.

Not only is it important for equipment managers to be familiar with this subject, it is also important for project owners, contract administrators, and others responsible for representing the project owner. By being familiar with equipment cost formulation, the owner's representative can more easily identify an inappropriate charge on a contract action.

What this report sets forth to provide is a clear and concise handbook for the equipment management process. It provides a basic overview of the subject and will allow the reader to develop a construction equipment management process based on his or her own set of criteria. 


\section{Equipment Economics}

\subsection{Time Value of Money}

It is an accepted fact that the value of money varies over time. Simply put, one dollar today will have more buying power than one dollar ten years from today. Similarly, one dollar deposited in a interest bearing savings account will grow to some value greater than one dollar in the future. Because the value of money changes over time, it is important for equipment managers to consider this time value of money when making decisions on different equipment options. By reviewing the economic impacts of each option the equipment manager can ensure the least expensive option is chosen. He does this by developing equivalence models for each option. Equivalence is a concept that looks at the value of two different options and determines the equivalent value of each option based on interest and number of payments. For example; $\$ 1,000$ is deposited in an account earning $10 \%$ per year, so the value of that account at the end of the first year will be $\$ 1,100$. Therefore, it is said that $\$ 1,000$ today is equivalent to $\$ 1,100$ one year from today, provided the interest rate is $10 \%$.

\subsection{Compound Interest Factors}

Compound interest factors are obtained from simple mathematical formulas.

These factors provide a simple means for analyzing economic alternatives to determine equivalence. Most economic texts have tables with compound interest factors in tabulated form. Appendix 1 of this report contains compound interest tables for convenience.

The following notations will be used in the compound interest factors to be discussed subsequently:

$\mathrm{P}=$ The present value of a sum of money. For example: equipment purchase price, loan amount, down payment etc.

$\mathrm{A}=\mathrm{A}$ uniform series of end of period payments. Loan payments are an example.

$F=$ A future sum of money.

$n=$ The number of interest periods.

$i=$ The interest rate per period. 


\subsubsection{Single Payment Factors}

Single payment factors are used to compare single present values to single future values and visa versa.

\subsubsection{Single Payment Compound Amount Factor}

The single payment compound amount factor is used to obtain the future value of a present sum of money based on an interest rate $i$ and a number of interest periods $n$, where:

$$
F=P(1+i)^{n}
$$

and $(1+i)^{n}$ is the single payment compound amount factor. The functional notation for this factor is $(\mathrm{F} / \mathrm{P}, i, n)$, and these factors can be found tabulated in Appendix 1.

\section{Example 2-1}

A contractor purchased a grader for $\$ 250,000$ today. The contractor expects to purchase another grader in 5 years. The contractor assumes that anmual inflation will be $6 \%$. How much will the same grader cost in 5 years?

Solution

From Appendix 1, $(F / P, 6 \%, 5)=1.3382$

Grader Cost in 5 years $=1.3382 \times \$ 250,000=\underline{\$ 334,550}$

\subsubsection{Single Payment Present Worth Factor}

The single payment present worth factor is used to obtain the present value of a future sum of money based on an interest rate $i$ and a number of interest periods $n$, where:

$$
P=F \times(1+i)^{-n}
$$

and $(1+i)^{-n}$ is the single payment present worth factor. The functional notation for this factor is $(\mathrm{P} / \mathrm{F}, i, n)$, and these factors can be found tabulated in Appendix 1.

\section{Example 2-2}

The contractor assumes the grader in example 2-I will need a replacement blade in 3 years. The blade is expected to cost $\$ 3000$ in 3 years. The contractor feels he can earn $8 \%$ interest on investments. How much will the contractor need to invest today in order to accumulate $\$ 3000$ in 3 years based on $8 \%$ interest?

Solution

From Appendix 1, $(P / F, 8 \%, 3)=0.7938$

Investment needed $=0.7938 \times \$ 3,000=\underline{\$ 2381.40}$ 


\subsubsection{Uniform Series Factors}

Uniform series factors are used to determine what a known uniform series of payments future or present value will be. They are also used to determine what value of uniform payment will result in a known present or future sum of money.

\subsubsection{Uniform Series Capital Recovery Factor}

The uniform series capital recovery factor is used to obtain the series of equal payments that are equal to a know present sum of money based on an interest rate $i$ and a number of interest periods $n$, where:

$$
A=P \times\left[i(1+i)^{n}\right] /\left[(1+i)^{n}-1\right]
$$

and $\left[i(1+i)^{n}\right] /\left[(1+i)^{n}-1\right]$ is the uniform series capital recovery factor. The functional notation for this factor is (A/P, $i, n)$, and these factors can be found tabulated in Appendix 1 .

\section{Example 2-3}

A contractor has found a used tractor with a price of $\$ 25,000$. The contractor wishes to finance this purchase. The bank offers a 5 year loan at $12 \%$ interest compounded annually with the payments due at the end of each year. What will the contractor's annual payments be?

Solution

From Appendix $1,(A / P, 5,12 \%)=0.2774$

Five annual payments $=0.2774 \times \$ 25,000=\underline{\$ 6.935}$

\subsubsection{Uniform Series Present Worth Factor}

The uniform series present worth factor is used to obtain the present worth of a series of known payments based on an interest rate $i$ and a number of interest periods $n$, where:

$$
\mathbf{P}=\mathbf{A} \times\left[(1+i)^{n}-1\right] /\left[i(1+i)^{n}\right]
$$

and $\left[(1+i)^{n}-1\right] /\left[i(1+i)^{n}\right]$ is the uniform series present worth factor. The functional notation for this factor is $(\mathrm{P} / \mathrm{A}, i, n)$, and these factors can be found tabulated in Appendix 1. 


\subsubsection{Uniform Series Sinking Fund Factor}

The uniform series sinking fund factor is used to obtain the uniform series of investments required to accumulate a desired future sum of money base on an interest rate $i$ and a number of interest periods $n$, where:

$$
A=F \times i /\left[(1+i)^{n}-1\right]
$$

and $i /\left[(1+i)^{n}-1\right]$ is the uniform series sinking fund factor. The functional notation for this factor is (A/F, $i, n)$, and these factors can be found tabulated in Appendix 1.

\section{Example 2-4}

A contractor is attempting to plan ahead by making anmual investments, which will be used to accumulate money for the future purchase a piece of equipment. The piece of equipment is anticipated to cost $\$ 500,000$ and will be needed 10 years from today. The contractor elects to make annual contributions to a fixed income type investment, which earns $5 \%$ interest compounded anmually. What will the contractor's required annual contribution be?

Solution

From Appendix $1,(A / F, 5 \%, 10)=0.0795$

Ten anmual contributions $=0.0795 \times \$ 500,000=\underline{\$ 39,750}$

\subsubsection{Uniform Series Compound Amount Factor}

The uniform series compound amount factor is used to obtain the future worth of a series of equal payments based on an interest rate $i$ and a number of interest periods $n$, where:

$$
\mathrm{F}=\mathrm{A} \times\left[(1+i)^{n}-1\right] / i
$$

and $\left[(1+i)^{n}-1\right] / i$ is the uniform series compound amount factor. The functional notation for this factor is $(\mathrm{F} / \mathrm{A}, i, n)$, and these factors can be found tabulated in Appendix 1 .

\subsection{Depreciation Techniques}

Depreciation is defined by the Bureau of Internal Revenue code as "a reasonable allowance for the exhaustion, wear and tear of property used in the trade or business, including a reasonable allowance for obsolescence. ${ }^{.(2-2 * 6)}$ There are two reasons for 
depreciating equipment. The first reason is to establish you tax liability, and the second reason is to determine the depreciation component of an equipment cost. It is legal to use two different methods of depreciation for the two different reasons. Often owners will elect to use the fastest depreciation technique, thus reducing the tax liability more quickly over the first few years of an equipment's useful life. However, if the equipment is sold for more than its depreciated book value, the excess will be treated as ordinary income and taxed accordingly.

There are several methods of depreciation recognized by the Internal Revenue Service. Three of the methods typically used for construction equipment are discussed in detail subsequently. A graphical comparison of three of these methods is shown in Figure $2-1$.

\subsubsection{Straight Line}

The straight line method of depreciation results in equal annual depreciation amounts. The following formula is used to calculate straight line depreciation:

\section{$D_{n}=\underline{\text { Initial Cost }- \text { Salvage Value }}$ $\mathbf{N}$}

Where $D_{n}=$ Depreciation for year in question

$\mathrm{N}=$ Equipment life in years 


\section{Example 2-5}

Using straight line depreciation calculate the depreciation for a piece of equipment with a purchase price of $\$ 120,000$ and an expected salvage value of $\$ 18,000$. The equipment is expected to have a life of 8 years. Provide tabulated results.

\section{Solution}

$$
\begin{gathered}
D_{1,2 \ldots .8}=\frac{\$ 120,000-\$ 18,000}{8} \\
D_{n}=\underline{\$ 12,750}
\end{gathered}
$$

\begin{tabular}{|c|c|c|c|}
\hline Year & Beginning Value & Depreciation & $\begin{array}{c}\text { End of Year Book } \\
\text { Value }\end{array}$ \\
\hline \hline 1 & $\$ 120,000$ & $\$ 12,750$ & $\$ 107,250$ \\
\hline 2 & $\$ 107,250$ & $\$ 12,750$ & $\$ 94,500$ \\
\hline 3 & $\$ 94,500$ & $\$ 12,750$ & $\$ 81,750$ \\
\hline 4 & $\$ 81,750$ & $\$ 12,750$ & $\$ 69,000$ \\
\hline 5 & $\$ 69,000$ & $\$ 12,750$ & $\$ 56,250$ \\
\hline 6 & $\$ 56,250$ & $\$ 12,750$ & $\$ 43,500$ \\
\hline 7 & $\$ 43,500$ & $\$ 12,750$ & $\$ 30,750$ \\
\hline 8 & $\$ 30,750$ & $\$ 12,750$ & $\$ 18,000$ \\
\hline
\end{tabular}

\subsubsection{Sum Of the Years Digit}

The sum of the years digit method of depreciation produces non-uniform depreciation, with the largest amount of depreciation occurring in the first few years of depreciation. The depreciation amount is calculated by multiplying the total amount of depreciation (Initial Cost - Salvage Value) by a depreciation factor. The depreciation factor is obtained by taking the year number, in reverse order, and dividing by the sum of the number of years in the depreciation cycle. The following are the formulas for obtaining the depreciation factors for the sum of the years digit method:

$$
\begin{gathered}
D_{f}(\text { year } 1)=n \div(1+2 \ldots+n) \\
D_{f}(\text { year } 2)=n-1 \div(1+2 \ldots .+n) \\
D_{f}(\text { year } 3)=n-2 \div(1+2 \ldots+n) \\
D_{f}(\text { year } n)=1 \div(1+2 \ldots+n)
\end{gathered}
$$

Where $D_{f}=$ Depreciation factor for year being considered $\mathrm{n}=$ Number of years in depreciation cycle 


\section{Example 2-6}

Using the same information from Example 2-5 calculate depreciation using the sum of the years digit method and tabulate results.

\section{Solution}

$$
\begin{aligned}
& D_{f}(\text { year } 1)=8 \div 36=0.2222 \quad D_{f}(\text { year } 5)=4 \div 36=0.1111 \\
& D_{f} \text { (year 2) }=7 \div 36=0.1944 \quad D_{f}(\text { year } 6)=3 \div 36=0.0833 \\
& D_{f}(\text { year } 3)=6 \div 36=0.1667 \quad D_{f}(\text { year } 7)=2 \div 36=0.0556 \\
& D_{f}(\text { year } 4)=5 \div 36=0.1389 \quad D_{f}(\text { year } 8)=1 \div 36=0.0278 \\
& D_{n}=D_{f} x(\text { Total Depreciation })=D_{f} \times \$ 102,000.00
\end{aligned}
$$

\begin{tabular}{|c|r|c|r|r|}
\hline Year & $\begin{array}{c}\text { Beginning } \\
\text { Value }\end{array}$ & $\begin{array}{c}\text { Depreciation } \\
\text { Factor }\end{array}$ & Depreciation & $\begin{array}{c}\text { End of Year } \\
\text { Book Value }\end{array}$ \\
\hline \hline 1 & $\$ 120,000.00$ & 0.2222 & $\$ 22,664.40$ & $\$ 97,335.60$ \\
\hline 2 & $\$ 97,335.60$ & 0.1944 & $\$ 19,828.80$ & $\$ 77,506.80$ \\
\hline 3 & $\$ 77,506.80$ & 0.1667 & $\$ 17,003.40$ & $\$ 60,503.40$ \\
\hline 4 & $\$ 60,503.40$ & 0.1389 & $\$ 14,167.80$ & $\$ 46,335.60$ \\
\hline 5 & $\$ 46,335.60$ & 0.1111 & $\$ 11,332.20$ & $\$ 35,003.40$ \\
\hline 6 & $\$ 35,003.40$ & 0.0833 & $\$ 8,496.60$ & $\$ 26,506.80$ \\
\hline 7 & $\$ 26,506.80$ & 0.0556 & $\$ 5,671.20$ & $\$ 20,835.60$ \\
\hline 8 & $\$ 20,835.60$ & 0.0278 & $\$ 2,835.60$ & $\$ 18,000.00$ \\
\hline
\end{tabular}

\subsubsection{Declining Balance}

The declining balance method of depreciation is similar to the sum of the years digit method in that the highest levels of depreciation occur in the first few years of depreciation. Unlike the sum of the years digit method, when using the declining balance method, the depreciation amount for a given year is obtained by multiplying the book value at the beginning of the year being considered by a depreciation factor. Depreciation factors for declining balance depreciation are obtained from the following formula:

$$
\mathbf{D}_{\mathbf{f}}=\mathbf{D B}_{\mathbf{f}} \div \mathbf{N}
$$

Where $D_{f}=$ Depreciation factor

$\mathrm{DB}_{\mathrm{f}}=$ Declining Balance Factor $(2=$ Double Declining, $3=$ Triple Declining, $4=$ Quadruple Declining, etc.)

$\mathrm{N}=$ Number of years in depreciation cycle 
Although any declining balance factor can, in theory, be used for calculating declining balance depreciation, the most common factor is the double declining balance factor.

\section{Example 2-7}

Using the same information from Example 2-5 calculate depreciation using double declining balance and tabulate results.

\section{Solution}

$$
\begin{gathered}
D_{f}=2 \div 8=\underline{0.25} \\
D_{n}=D_{f} x \text { Years Beginning Value }
\end{gathered}
$$

\begin{tabular}{|c|r|c|r|r|}
\hline Year & $\begin{array}{c}\text { Beginning } \\
\text { Value }\end{array}$ & $\begin{array}{c}\text { Depreciation } \\
\text { Factor }\end{array}$ & Depreciation & $\begin{array}{c}\text { End of Year } \\
\text { Book Value }\end{array}$ \\
\hline \hline 1 & $\$ 120,000.00$ & .25 & $\$ 30,000.00$ & $\$ 90,000.00$ \\
\hline 2 & $\$ 90,000.00$ & .25 & $\$ 22,500.00$ & $\$ 67,500.00$ \\
\hline 3 & $\$ 67,500.00$ & .25 & $\$ 16,875.00$ & $\$ 50,625.00$ \\
\hline 4 & $\$ 50,625.00$ & .25 & $\$ 12,656.25$ & $\$ 37,968.75$ \\
\hline 5 & $\$ 37,968.75$ & .25 & $\$ 9,492.19$ & $\$ 28,476.56$ \\
\hline 6 & $\$ 28,476.56$ & .25 & $\$ 7,119.14$ & $\$ 21,357.42$ \\
\hline 7 & $\$ 21,357.42$ & .25 & $\$ 3,357.42^{*}$ & $\$ 18,000.00$ \\
\hline 8 & $\$ 18,000.00$ & .25 & $\$ 0.00^{*}$ & $\$ 18,000.00$ \\
\hline
\end{tabular}

*Note: In year 7 the depreciation by calculation is $\$ 5,339.36$, however, you can not reduce the book value below that of the given $\$ 18,000.00$. Therefore, the depreciation amount in year 7 and 8 are reduced accordingly. 
Figure 2-1

Comparison of Depreciation Methods

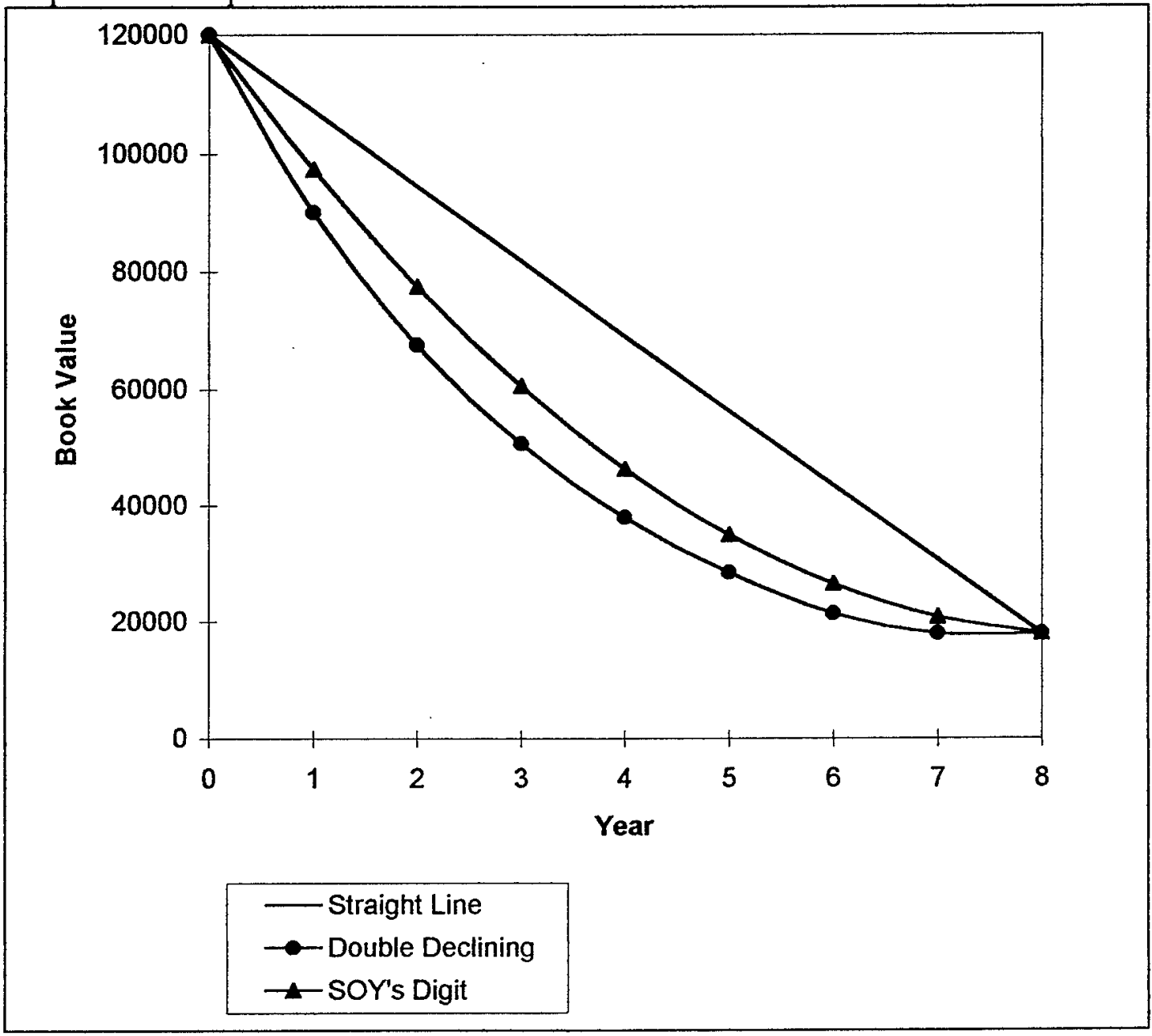




\section{Cost of Equipment}

\subsection{Elements of Equipment Cost}

There are two basic elements of equipment cost. These two elements are ownership costs and operating costs. It is understood that your equipment must pay for itself, therefore it is imperative that equipment owners accurately calculate ownership and operating costs for their equipment. By accurately calculating these costs, the equipment owner can confidently assign a cost that will result in the equipment being profitable.

Generally, ownership and operating costs are calculated based on an hourly rate. The reason for calculating these costs on an hourly basis is because that is how they are normally billed on construction projects.

\subsection{Ownership Costs}

Ownership costs are those costs which the owner will incur regardless of whether the equipment is used or not. Typical ownership costs are listed below.

- Depreciation

- Interest (Investment, Cost of Capital)

- Insurance

- Taxes

- Storage

The owner accounts for depreciation by knowing the purchase price and estimating a salvage value and equipment useful life. The remaining items: interest, insurance, taxes, and storage will be used to develop a minimum attractive rate of return. Minimum attractive rate of return will be detailed in a subsequent example.

Interest is the cost resulting from borrowed money. The equipment owner should account for this cost even if money is not borrowed, as the cash used to purchase the equipment will no longer be available to earn interest in a savings or investment vehicle. Insurance costs are for liability and equipment damage protection. Taxes covers those costs associated with personal property taxes. Storage costs are for those times when the equipment is not employed on a job. 
As discussed previously, an equipment owner will need to make an estimate on a piece of equipment's useful life in order to calculate depreciation. One of the more common means of estimating useful life is through the use of tables provided by manufactures. Table 3-1 is an example of the type of table a manufacturer might provide.

Table 3-1

Estimated Useful Life of Construction Equipment (Total Operating Hours)

\begin{tabular}{lccc}
\hline & \multicolumn{3}{c}{ Operating Conditions } \\
\hline \multicolumn{1}{c}{ Equipment } & Favorable & Average & Unfavorable \\
\hline Crawler tractor & 15,000 & 12,000 & 10,000 \\
Grader & 20,000 & 15,000 & 12,000 \\
Excavator & 15,000 & 12,000 & 10,000 \\
Hauler & 25,000 & 20,000 & 15,000 \\
Scraper & 16,000 & 12,000 & 10,000 \\
Tracked loader & 10,000 & 8,000 & 6,000 \\
Wheeled loader & 12,000 & 10,000 & 8,000 \\
\hline
\end{tabular}

Data for this table was extracted from Reference 6, p. 27

Two methods of calculating ownership costs will be detailed here. The first method uses the principles of equipment economics covered earlier, and is known as the Amortized Method. The second method is an approximate method known as the Average Annual Investment Method. An example of each method is detailed in the following problems.

\subsubsection{Amortized Method}

The following example describes the method for obtaining a piece of equipment's ownership cost by the amortized method.

\section{Example 3-1}

A contractor purchases a scraper for $\$ 150,000$ and estimates it will be used 2000 hrs each year and will have a salvage value at the end of its useful life of about $10 \%$ of purchase price. The contractor figures his ownership cost factors as:

- Interest $8 \%$

- Insurance $2 \%$

- Toxes $1 \%$

- Storage $1 \%$ 
What will the contractor's hourly ownership cost $\left(C_{\text {own }}\right)$ be for the scraper described above for favorable conditions?

\section{Solution}

Step 1 - Calculate period of ownership

ownership period $=$ estimated useful life $\div$ yearly usage $=16,000 \mathrm{hrs} \div 2000 \mathrm{hrs} / \mathrm{yr}$

Ownership period $=8$ years

Step 2 - Calculate minimum attractive rate of return (MARR)

$M A R R=$ Interest + Insurance + Taxes + Storage $=8 \%+2 \%+1 \%+1 \%$

$$
M A R R=12 \%
$$

Step 3 - Calculate the present value (PV) of the salvage value salvage value $=0.10 \times \$ 150,000=\$ 15,000$

$(P / F, 12 \%, 8)=0.4039$

$$
P V \text { of salvage }=0.4039 \times \$ 15,000
$$$$
P V \text { of salvage }=\$ 6,058.50
$$

Step 4 -Calculate the total present value of the scraper

Total present value $=$ Initial Cost - PV of salvage $=\$ 150,000-\$ 6,058.50$

$$
\text { Total present value }=\$ 143,941.50
$$

Step 5 - Calculate the anmual ownership cost of the scraper

Annual Ownership Cost = Total Present Value $x(A / P, 12 \%, 8)$

Annual Ownership Cost $=\$ 143,941.50 \times 0.2013$

Annual Ownership Cost $=\$ 28,975.42$

Step 6 - Calculate hourly ownership cost $\left(C_{\text {own }}\right)$

$C_{\text {own }}=$ Annual Ownership Cost $\div$ Anmual hourly usage $=\$ 28,975.42 \div 2,000 \mathrm{hrs} / \mathrm{yr}$

$$
C_{\text {own }}=\underline{\$ 14.49 / \mathrm{hr}}
$$

The hourly ownership cost obtained in this example represents the total hourly rate to cover all of the ownership costs associated with this scraper.

\subsubsection{Average Annual Investment Method}

Another method for determining ownership costs is known as the average investment method. This method is an approximation, and should only be used for useful life periods of less than ten years. The formula for calculating average annual investment follows:

$$
\text { If no salvage: } \mathbf{P}_{\text {avg }}=\mathbf{P}(\mathbf{N}+\mathbf{1}) \div 2 \mathbf{N}
$$

If Salvage is to be included: $\mathbf{P}_{\text {avg }}=[\mathbf{P}(\mathbf{N}+\mathbf{1})+\mathbf{S}(\mathbf{N}-\mathbf{1})] \div 2 \mathbf{N}$

Where Pavg $=$ average annual investment

$\mathrm{P}=$ initial equipment cost 


$$
\begin{aligned}
& \mathrm{N}=\text { useful life in years } \\
& \mathrm{S}=\text { salvage value }
\end{aligned}
$$

To obtain the investment cost $\left(\mathrm{C}_{\mathrm{inv}}\right)$ based on the average annual investment you multiply Pavg by the minimum attractive rate of return (MARR).

\section{$C_{\text {inv }}=$ Pavg $\times$ MARR}

This method does not account for the cost of depreciation $\left(\mathrm{C}_{\mathrm{dep}}\right)$, so it must be added separately to obtain the total ownership cost.

$$
\mathbf{C}_{\text {own }}=\mathbf{C}_{\text {dep }}+C_{\text {inv }}
$$

The following example illustrates the details of obtaining ownership costs based on the average annual investment method.

\section{Example 3-2}

Calculate the hourly ownership cost $\left(\mathrm{C}_{\mathrm{own}}\right)$ for the scraper described in Example 3-I using the Average Anmual Imestment Method. All conditions remain the same.

\section{Solution}

Step I - Calculate the average anmual investment $\left(P_{\text {avg }}\right)$

$$
\begin{gathered}
P_{\text {avg }}=[P(N+1)+S(N-1)] \div 2 N=[\$ 150,000(8+1)+\$ 15,000(8-1)] \div 2(8) \\
\text { Pavg }=\$ 90,937.50
\end{gathered}
$$

Step 2 - Calculate investment cost $\left(C_{\text {inv }}\right)$

$$
\begin{gathered}
C_{\text {inv }}=P_{\text {avg }} \times M A A R=\$ 90,937.50 \times 12 \% \\
C_{i n v}=\$ 10,912.50 / y r \div 2000 \mathrm{hrs} / \mathrm{yr}=\$ 5.46 / \mathrm{hr} \\
C_{\text {inv }}=\$ 5.46 / \mathrm{hr}
\end{gathered}
$$

Step 3 - Calculate depreciation cost $\left(C_{\text {dep }}\right)$

$$
\text { Cdep }=(\text { Initial Purchase Price }- \text { Salvage Value }) \div \text { estimated useful life }
$$

$$
\begin{gathered}
C_{d e p}=(\$ 150,000-\$ 15,000) \div 16000 \mathrm{hrs} \\
C_{d e p}=\$ 8.44 / \mathrm{hr}
\end{gathered}
$$

Step 4 - Calculate the hourly ownership cost $\left(C_{\text {own }}\right)$

$$
\begin{gathered}
C_{\text {own }}=C_{d e p}+C_{\text {inv }}=\$ 8.44 / \mathrm{hr}+\$ 5.46 / \mathrm{hr} \\
\text { Cown }=\underline{\$ 13.90 / \mathrm{hr}}
\end{gathered}
$$


The results of examples 3-1 and 3-2 show that these two methods differ only slightly in the end result. That being the case, it should still be noted that the amortized method is the more accurate of the two methods.

\subsection{Operating Costs}

Operating costs are those costs that are incurred only when the equipment is in use. One of the best sources for obtaining operating costs is historical data. Most equipment manufacturers provide tables of adjustment factors to aid equipment owners in estimating equipment operating costs. The following is a list of those items that are generally considered operating costs.

- Fuel Costs

- Lubrication Costs

- Repair Costs

- Tire Costs

- Special Items

- Operators Wages

The sum of these individual costs will represent the total operating cost of a piece of equipment, and the sum of the total operating cost and total ownership cost will represent the total equipment cost.

\section{Total Equipment Cost $=$ Total Ownership Costs + Total Operating Costs}

\subsubsection{Fuel Costs}

The cost of fuel will be obtained by multiplying a given piece of equipment's hourly fuel burn in gallons per hour by the cost of fuel in dollars per gallon. A load factor is usually applied to the basic fuel burn. Table 3-2 is an example of a fuel consumption load factor table. Hourly fuel burn will be provided with most manufactures equipment performance data. However, if fuel burn is unavailable the hourly fuel burn can be estimated with the following formulas:

Gasoline Engines

$$
Q=(0.7 \times \mathrm{hp} \times \mathrm{load} \text { factor }) \div 6.2 \mathrm{gph}
$$


Diesel Engines

$$
Q=(0.5 \times \text { hp } \times \text { load factor }) \div 7.2 \mathrm{gph}
$$

Where $Q=$ Fuel Burn (gallons per hour)

$\mathrm{hp}=$ Equipment Horsepower

Table 3-2

Load Factors for Fuel Consumption

\begin{tabular}{lccc}
\hline & \multicolumn{3}{c}{$\begin{array}{c}\text { Operating } \\
\text { Conditions }\end{array}$} \\
\hline \multicolumn{1}{c}{ Equipment } & Favorable & Average & Severe \\
\hline Wheel Type, on pavement & 0.25 & 0.30 & 0.40 \\
Wheel Type, off pavement & 0.50 & 0.55 & 0.60 \\
Tracked Crawler & 0.50 & 0.63 & 0.75 \\
Power Excavator & 0.50 & 0.55 & 0.60 \\
\hline
\end{tabular}

Data for this table was extracted from Reference 1, p. 33

\section{Example 3-3}

What would the estimated hourly cost of fuel be for a 30 horsepower diesel wheel type loader used off road if the cost of diesel is \$1.25/gallon and operating conditions are average?

\section{Solution}

$$
\begin{aligned}
& \text { Step } 1 \text { - Calculate hourly fuel burn }(Q) \\
& \qquad \begin{aligned}
Q=(0.5 \times \text { hp } \times \text { load factor }) \div 7.2 \mathrm{gph}=(0.5 \times 30 \times 0.55) \div 7.2 \mathrm{gph} \\
\qquad=\mathbf{1 . 1 4} \mathrm{gph}
\end{aligned}
\end{aligned}
$$

Step 2 - Calculate fuel cost per hour $\left(C_{\text {fuel }}\right)$

$$
\begin{gathered}
C_{\text {fuel }}=Q \times \text { Cost of fuel per gallon }=1.14 \mathrm{gph} \times \$ 1.25 / \mathrm{gallon} \\
\qquad C_{\text {fuel }}=\underline{\$ 1.42 / \mathrm{hr}}
\end{gathered}
$$

\subsubsection{Lubrication Costs}

Lubrication costs are those costs associated with equipment lubrication, hydraulic fluids, oil filters, grease, etc.. Lubrication costs are best estimated from historical data. Once enough historical data is obtained you can reduce lubrication costs to a percentage of fuel costs.

\subsubsection{Repair Costs}

Repair costs are those cost associated with other than routine maintenance and tires. Again, repair costs are best estimated from historical real data. 


\subsubsection{Tire Costs}

Tire costs is not a negligible cost when it comes to heavy equipment. Replacing four tires on a loader might cost upwards of $\$ 10,000$. Hence, tire costs is an operating cost element all its own. Tire life will vary widely based on the operating conditions, therefore tire costs is somewhat difficult to estimate. As mentioned previously, historical data is the best method for estimating tire life and costs. However, there are various tables available for estimating tire life. Table 3-3 is an example of a tire life estimating aid. Tire repair will add about $15 \%$ to tire replacement cost. ${ }^{(3-494)}$ The following equation can be used to estimate tire cost:

\section{Tire Cost $(\$ / h r)=($ Cost of set of tires $) \div($ Estimated tire life $)$}

Table 3-3

Typical Tire Life (hrs)

\begin{tabular}{lccc}
\hline & & $\begin{array}{c}\text { Operating } \\
\text { Conditions }\end{array}$ \\
\hline \multicolumn{1}{c}{ Equipment } & Favorable & Average & Severe \\
\hline Dozers and loaders & 3,200 & 2,100 & 1,300 \\
Motor graders & 5,000 & 3,200 & 1,900 \\
Scrapers & & & \\
$\quad$ Conventional & 4,600 & 3,300 & 2,500 \\
$\quad$ Twin Engine & 4,000 & 3,000 & 2,300 \\
$\quad$ Push-pull and elevating & 3,600 & 2,700 & 2,100 \\
Trucks and wagons & 3,500 & 2,100 & 1,100 \\
\hline
\end{tabular}

Data for this table was extracted from Reference 3, p. 494

\subsubsection{Special Items}

Special items represents the cost associated with high-wear items. Examples of these type of items include, but are not limited to, scraper blade cutting edges and ripper tips. Hourly costs for these items are calculated by simply dividing the cost of the item by the expected life of the item. 


\subsubsection{Operators Wages}

The last item to be included in the operating cost of a piece of equipment is the operator's wages. Some equipment may require a second laborer to serve as a spotter or oiler, and their wages should be included as well.

\section{Example 3-4}

A contractor wishes to calculate the total hourly ownership and operating cost for a diesel powered wheeled loader. Based on the following information, calculate the loader's total ownership and operating cost (use the amortized method for ownership cost calculation):

Ownership Costs

Initial purchase price $=\$ 110,000$

Estimated salvage value $=\$ 15,000$

Operating conditions $=$ Favorable

Estimated anmual usage $=2000 \mathrm{hrs}$

$M A R R=15 \%$

Rated horsepower $=400 \mathrm{hp}$

Lubrication $=10 \%$ of Fuel Cost

Repairs (lifetime of equipment) $=30 \%$ of initial purchase price

Tires (off road usage) $=\$ 8,000$ (set)

Special Items $=$ None

Operator $=\$ 16.00 / \mathrm{hr}$

Diesel fuel $=\$ 1.05 / \mathrm{gal}$

Step 1 - Calculate ownership period

Ownership period $=12,000 \mathrm{hrs} \div 2000 \mathrm{hrs} / \mathrm{yr}$

Ownership period $=6$ years

Step 2 - Calculate total present value (PV) of loader

$P V=$ Initial Purchase - [Salvage $x(P / F, 15 \%, 6)]$

$P V=\$ 110,000-(\$ 15,000 \times 0.4323)$

$$
P V=\$ 103,515.50
$$

Step 3 - Calculate the hourly ownership cost $\left(C_{\text {own }}\right)$

$$
\begin{gathered}
C_{\text {own }}=\text { Anmual Ownership Cost } \div \text { Annual usage } \\
C_{\text {own }}=[\$ 103,515.50 \times(A / P, 15 \%, 6)] \div 2000 \mathrm{hrs} \\
C_{\text {own }}=(\$ 103,515.50 \times 0.2642) \div 2000 \mathrm{hrs} \\
C_{\text {own }}=\$ 13.67 / \mathrm{hr}
\end{gathered}
$$

\section{Operating Cost}

Step 1 - Calculate hourly fuel cost $\left(C_{\text {fue }}\right)$

$$
\begin{gathered}
Q=(0.5 \times 400 h p x .25) \div 7.2 g p h \\
Q=6.94 g p h
\end{gathered}
$$




$$
\begin{gathered}
C_{\text {fuel }}=6.94 \mathrm{gph} \times \$ 1.05 / \mathrm{gal} \\
C_{\text {fuel }}=\$ 7.29 / \mathrm{hr}
\end{gathered}
$$

Step 2 - Calculate hourly lubrication cost $\left(C_{\text {lube }}\right)$

$$
C_{\text {lube }}=0.10 \times \$ 7.29 / \mathrm{hr}=\$ .73 / \mathrm{hr}
$$

Step 3 - Calculate hourly repair cost $\left(C_{\text {rep }}\right)$

$$
\begin{gathered}
C_{\text {rep }}=(0.30 \times \$ 110,000) \div 15,000 \mathrm{hrs} \\
C_{\text {rep }}=\$ 2.20 \mathrm{hr}
\end{gathered}
$$

Step 4 - Calculate hourly tire cost $\left(C_{\text {tire }}\right)$

$$
\begin{gathered}
C_{\text {tire }}=\$ 8,000 / 3,200 \mathrm{hrs} \\
C_{\text {tire }}=\$ 2.50 \mathrm{hr}
\end{gathered}
$$

Step 5 - Calculate hourly operator wages $\left(C_{\text {wage }}\right)$

$$
C_{\text {wage }}=\$ 16.00 / \mathrm{hr}
$$

Step 6 - Calculate total operating cost $\left(C_{\text {oper }}\right)$

$$
\begin{gathered}
C_{\text {oper }}=C_{\text {fuel }}+C_{\text {lube }}+C_{\text {rep }}+C_{\text {tire }}+C_{\text {wage }} \\
C_{\text {oper }}=\$ 7.29+\$ .73+\$ 2.20+\$ 2.50+\$ 16.00 \\
C_{\text {oper }}=\$ 28.72 / \mathbf{h r}
\end{gathered}
$$

Total equipment cost $=$ Cown + Coper $=\$ 13.67+\$ 28.72=\underline{\$ 42.39 / \mathrm{hr}}$

\subsection{Sources of Tabulated Equipment Costs}

There are several sources of tabulated equipment costs that equipment owners or managers can use to obtain estimates of equipment ownership and operating costs. Two sources that will be briefly discussed here, are the Army Corps of Engineers Construction Equipment Ownership and Operating Expense Schedule and the Rental Rate Blue Book. These two publications use different methods for obtaining their respective ownership and operating costs. Thus, the rates in each will generally differ to some extent.

\subsubsection{Army Corps of Engineers}

The Army Corps of Engineers Construction Equipment Ownership and Operating Expense Schedule is published primarily for the use of government contracting agencies as a guide to verifying and estimating contractor equipment charges on government projects. This schedule attempts to represent, as realistically as possible, actual ownership and operating costs. A review of this book reveals that the Army applies a discount to the list price of equipment. This discount ranges from $7.5 \%$ to $15 \%$ of list price. It is generally 
accepted that contractors will receive some form of discount on equipment purchases, and the Army attempts to reflect this in calculating the ownership portion of an equipment's cost. The Army Corps of Engineers Construction Equipment Ownership and Operating Expense Schedule considers all those ownership and operating costs discussed previously in this report with the exception of operator's wages.

\subsubsection{Rental Rate Blue Book}

The Rental Rate Blue Book is published by Dataquest Incorporated. This book is also a source of estimated ownership and operating cost for equipment. This publication is somewhat conservative in comparison to the Army Corps of Engineers Construction Equipment Ownership and Operating Expense Schedule, as evidenced by the fact the manufacture's suggested list price is used in calculating the ownership cost of a piece of equipment. In using the manufactures suggested list price, the resulting ownership cost will typically be somewhat higher than what a contractor might actually incur in owning a piece of equipment. As with the Army Corps of Engineers Construction Equipment Ownership and Operating Expense Schedule, each of the ownership and operating costs discussed previously in this report are considered in the Rental Rate Blue Book's calculation of ownership and operating costs with the exception of operator's wages. 


\section{Soil Properties and Handling}

Heavy equipment in the construction industry is primarily employed in the excavation, hauling, stabilization, loading, placing, grading, and finishing of material in the earth's crust. This material consists primarily of soil and rock. Soil possesses some unique characteristics that must be considered in selecting equipment that will most efficiently carryout these tasks. Therefore, it is important that the equipment manager have a basic understanding of these characteristics.

\subsection{Soil Conditions}

Earthmoving material can be measured in three primary states. These states include:

- Bank Measure

- Loose Measure

- Compacted Measure

\subsubsection{Bank Measure}

Bank measure represents the volume of a soil before being disturbed. This is also sometimes referred to as in-place or in-situ. This measure will typically be abbreviated as $\mathrm{BCY}$ or BCM for bank cubic yard and bank cubic meter respectively.

\subsubsection{Loose Measure}

Loose measure represents the volume of a disturbed soil, or one that has been excavated or loaded. This measure will typically be abbreviated as LCY or LCM for loose cubic yard and loose cubic meter respectively.

\subsubsection{Compacted Measure}

Compacted measure represents the volume of a soil after it has been placed and compacted. This measure will typically be abbreviated as CCY or CCM for compacted cubic yard and compacted cubic meter respectively. 
Figure 4-1, Typical Volume Change During Earthmoving (Extracted from Reference 3, p. 30)

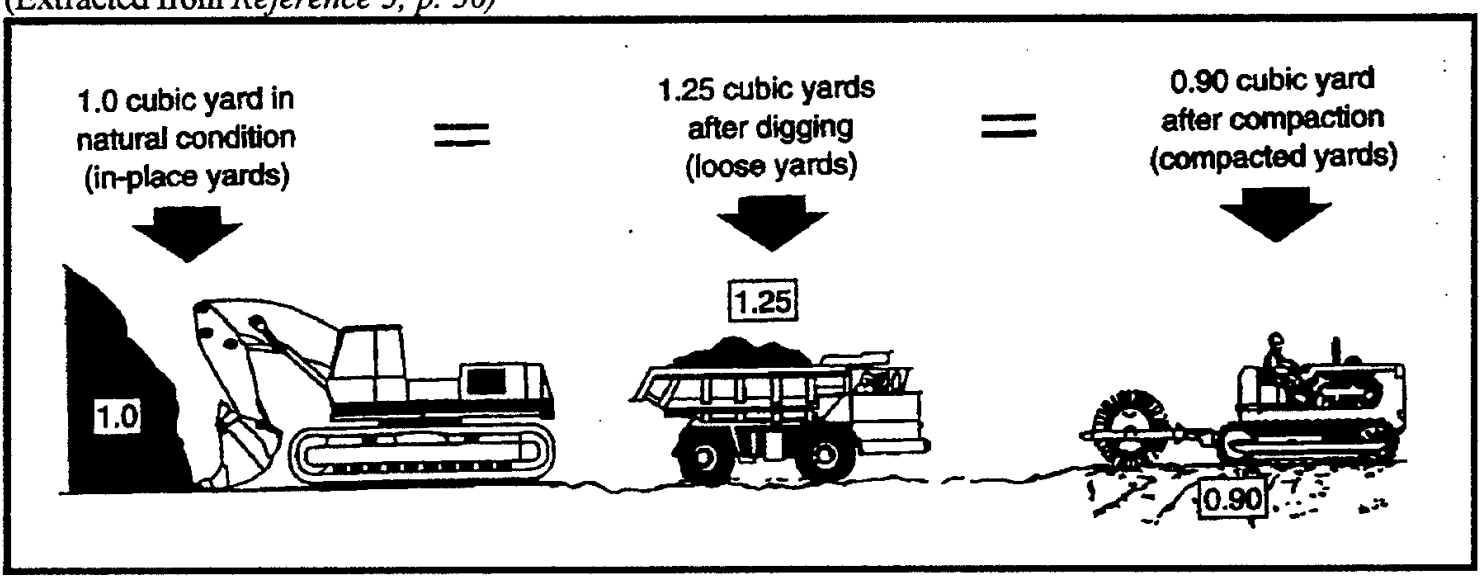

\subsection{Soil Swell}

When soil is excavated the particles become loose and voids are created. Thus, the volume of an excavated soil will be greater than that of the in-situ soil. This phenomenon is known as swell and is illustrated in Figure 4-1. The percentage of swell can be calculated from the following formula:

$$
\text { Swell }(\%)=[(\text { Bank Unit Weight } \div \text { Loose Unit Weight })-1] \times 100
$$

\section{Example 4-1}

Find the swell of a soil with an in-situ unit weight of 3,000 lb/cy and a 2,200 lb/cy unit weight after excavation:

$$
\text { Swell }=[(3,000 \div 2,200)-1] \times 100=\underline{36 \%}
$$

That is, 1 bank cubic yard (BCY) of this material will equal 1.36 loose cubic yards (LCY).

\subsection{Soil Shrinkage}

When soil is compacted those voids developed during excavation and hauling are eliminated. In fact, the soil becomes even more dense than in its in-situ state. This phenomenon is known as shrinkage. The percentage of shrinkage can be calculated from the following formula:

$$
\text { Shrinkage (\%) = }[1 \text { - (Bank Unit Weight } \div \text { Compacted Unit Weight) }] \times 100
$$




\section{Example 4-2}

Find the shrinkage of a soil with an in-situ unit weight of $2,800 \mathrm{lb} / \mathrm{cy}$ and a 3,500 lb/cy unit weight after compaction:

$$
\text { Shrinkage }=[1-(2,800 \div 3,500)] \times 100=\underline{\mathbf{2 0 \%}}
$$

That is, 1 bank cubic yard (BCY) of this material will equal 0.80 compacted cubic yards (CCY).

\subsection{Load and Shrinkage Factors}

It is often desirable to express earthmoving measures in a consistent measure, often bank measure. Therefore, load and shrinkage factors were developed to make converting between the three measures easier.

Haul units are often expressed in loose measure, therefore it is convenient to have a factor for converting loose measure to bank measure. This factor is known as the load factor and is expressed as follows:

\section{Load Factor $=$ Loose Unit Weight $\div$ Bank Unit Weight or

$$
\text { Load Factor }=1 \div(1+\text { swell })
$$$$
\text { and }
$$ \\ Load Factor $\times$ Loose Measure $=$ Bank Measure}

A factor was also developed for converting bank measure to compacted measure, and is known as the shrinkage factor. This factor is expressed as follows:

\section{Shrinkage Factor $=$ Bank Unit Weight $\div$ Compacted Unit Weight \\ or \\ Shrinkage Factor $=1$ - Shrinkage \\ and \\ Shrinkage Factor $\times$ Bank Measure $=$ Compacted Measure}

Some typical soil volume characteristics, with respect to earthmoving operations, are provided in Table 4-1. 


\section{Example 4-3}

$A$ soil has the following unit weights: 2,000 lb/LCY, 2,700 lb/BCY, and 3,400

$\mathrm{lb} / \mathrm{CCY}$. (a) What is the load factor and shrinkage factor for this soil? (b) How many $B C Y$ 's and CCY's will there be in 500,000 LCY's of this soil?

Solution

(a)

(b)

Load Factor $=2,000 \div 2,700=\underline{\mathbf{0 . 7 4}}$

Shrinkage Factor $=2,700 \div 3,400=\underline{0.79}$

$0.74 \times 500,000 L C Y=\underline{370.000 B C Y}$

$0.79 \times 370,000 B C Y=292,300 C C Y$

Table 4-1

Typical Soil Volume Change Characteristics*

\begin{tabular}{|c|c|c|c|c|c|c|c|}
\hline & \multicolumn{3}{|c|}{ Unit Weight (lb/cy) } & \multirow[b]{2}{*}{$\begin{array}{c}\text { Swell } \\
(\%)\end{array}$} & \multirow[b]{2}{*}{$\begin{array}{c}\text { Shrinkage } \\
(\%)\end{array}$} & \multirow[b]{2}{*}{$\begin{array}{l}\text { Load } \\
\text { Factor }\end{array}$} & \multirow[b]{2}{*}{$\begin{array}{c}\text { Shrinkage } \\
\text { Factor }\end{array}$} \\
\hline & Loose & Bank & Compacted & & & & \\
\hline Clay & 2310 & 3000 & 3750 & 30 & 20 & 0.77 & 0.80 \\
\hline Common Earth & 2480 & 3100 & 3450 & 25 & 10 & 0.80 & 0.90 \\
\hline Rock (blasted) & 3060 & 4600 & 3550 & 50 & $-30^{\star \star}$ & 0.67 & $1.30^{\star *}$ \\
\hline Sand and Gravel & 2860 & 3200 & 3650 & 12 & 12 & 0.89 & 0.88 \\
\hline
\end{tabular}

${ }^{\star}$ Exact Values vary with grain size distribution, moisture, compaction, and other factors. Tests are required to determine exact values for a specific soil.

${ }^{\star \star}$ Compacted rock, unlike soil, is less dense than in-place rock.

Data for this table was extracted from Reference 3, p. 33

\subsection{Spoil Banks}

It is often necessary to stockpile excavated material when performing earthmoving operations. As a result, one must be able to determine the size of the expected stockpile in order to determine an acceptable location for the stockpile. Stockpiled material can either be in the form of a spoil bank or spoil pile. Spoil banks are triangular in cross section and relatively long. Spoil piles are created when material is deposited from a fixed position, and they are conical in shape. The size of a spoil bank or pile is governed by the spoil material's angle of repose. Angle of repose is the angle measured from horizontal that the sides of a spoil bank or pile will naturally form when deposited. Table 4-2 list some common values for soil angle of repose. 
Triangular Spoil Banks

$$
\begin{gathered}
\text { Volume }=\text { Section Area } \times \text { Length } \\
B=[(4 V) \div(\mathrm{L} \times \tan \mathrm{R})]^{1 / 2} \\
H=(B \times \tan \mathrm{R}) \div 2
\end{gathered}
$$

Where $\mathrm{B}=$ base width

$\mathrm{H}=$ pile height

$\mathrm{L}=$ pile length

$R=$ angle of repose (deg)

$\mathrm{V}=$ pile volume

Conical Spoil Piles

$$
\begin{gathered}
\text { Volume }=1 / 3 \times \text { Base area } \times \text { Height } \\
\begin{array}{c}
D=[(7.64 V) \div(\tan R)]^{1 / 3} \\
H=(D \div 2) \times \tan R
\end{array}
\end{gathered}
$$

Where $\mathrm{D}=$ Diameter of pile base

Table 4-2

Typical Values For Excavated Soil Angle of Repose

\begin{tabular}{lc}
\hline Material & Angle of Repose (deg) \\
\hline Clay & 35 \\
Common earth, dry & 32 \\
Common earth, moist & 37 \\
Gravel & 35 \\
Sand, dry & 25 \\
Sand, moist & 37 \\
\hline
\end{tabular}

Data for this table was extracted from Reference 3, p. 34

\section{Example 4-4}

Find the base width and height of a spoil bank containing 100,000 BCY of material. The length of the bank is 500 feet, and the material is clay.

Solution

From Table 4-1 Swell for Clay $=30 \%$

From Table 4-2 Angle of repose for clay $=35^{\circ}$

Step 1 - Calculate Loose Volume

Loose Volume $=1.3 \times 100,000 B C Y \times 27 \mathrm{ft}^{3} / \mathrm{yd}^{3}=\underline{3,510,000 \mathrm{ft}^{3}}$

Step 2 - Calculate Base Width

$$
\begin{gathered}
\text { Base Width }=[(4 \times 3,510,000) \div(500 \times \text { tan } 359)]^{1 / 2} \\
\text { Base Width }=\underline{200 \text { feet }}
\end{gathered}
$$


Step 3 - Calculate Height

$$
\begin{gathered}
\text { Height }=\left(200 \times \tan 35^{\circ}\right) \div 2 \\
\text { Height }=\underline{70 \text { feet }}
\end{gathered}
$$

\section{Example 4-4}

Find the base diameter and height of a spoil pile containing 200 BCY of dry sand. Solution

From Table 4-I Swell for sand $=12 \%$

From Table 4-2 Angle of repose for dry sand $=25^{\circ}$

Step 1 - Calculate Loose Volume

$$
\text { Loose Volume }=1.12 \times 200 \times 27 \mathrm{ft}^{3} / y \mathrm{~d}^{3}=\underline{\mathbf{6}, 048 \mathrm{ft}^{3}}
$$

Step 2 - Calculate Base Diameter

$$
\text { Base Diameter }=[(7.64 \times 6,048) \div(\tan 259)]^{1 / 3}
$$

Base Diameter $=\underline{46 \text { feet }}$

Step 3 - Calculate Height

$$
\begin{gathered}
\text { Height }=(46 \div 2) \times \tan 25^{\circ} \\
\text { Height }=\underline{10.7 \text { feet }}
\end{gathered}
$$




\section{Productivity}

The production of any particular earthmoving operation consists of the following elements:

- Loading

- Hauling

- Dumping

- Return

- Spot

Most of these terms are self explanatory with the possible exception of spot. Spot represents the time necessary for a haul unit to maneuver into position for loading. These elements represent the total production of a particular earthmoving activity. To calculate the total production you must first be able to calculate the production of each individual piece of equipment involved in the operation. The production of a piece of equipment is based on cycle time and volumetric capacity of the equipment. Cycle time is the time required of a given piece of equipment to complete one cycle of its intended operation. Production can be calculated as:

\section{Production $=$ volume per cycle $\mathbf{x}$ cycles per hour $\mathbf{x}$ efficiency factor}

Because it is not possible to operate a piece of equipment at $100 \%$ efficiency, the production is reduced by some efficiency factor. There are two ways of estimating an efficiency factor. One method is to estimate the number of working minutes per hour, 50 minutes per hour or 0.833 is popular. The second method uses information obtained from tables similar to Table 5-1. Regardless of the method used, efficiency is effected by management conditions and job conditions.

\section{Management Conditions Include:}

- worker skill, training, and motivation

- selection, operation, and maintenance of equipment

- planning, job layout, supervision, and coordination 


\section{Job Conditions Include:}

- topography and work dimensions

- surface and weather conditions

- work methods or sequence

\section{Table 5-1}

Efficiency Factors For Earthmoving Operations

\begin{tabular}{lcccc}
\hline & & Management & Conditions & Poor \\
\hline Job Conditions & Excellent & Good & Fair & 0.70 \\
Good & 0.84 & 0.81 & 0.76 & 0.65 \\
Fair & 0.78 & 0.75 & 0.71 & 0.60 \\
Poor & 0.72 & 0.69 & 0.65 & 0.52 \\
\hline
\end{tabular}

Data for this table was extracted from Reference 3, p. 23 


\section{Excavating Equipment}

Excavating equipment consists of those machines designed with the primary purpose of digging. The primary members of the excavating family include hydraulic excavators, hydraulic backhoes, and the family of cable operated crane digging devices (shovels, draglines, hoes, and clamshells). Although dozers, scrapers, and loaders can perform excavating activities, excavation is not their primary function, and they will not be considered members of the excavating equipment family here.

\subsection{Shovels}

Shovels dig in much the same fashion as a person would dig with a hand shovel. The operation of the shovel is forward and usually the bucket provides for bottom dumping. An illustration of the front shovel's components is shown in Figure 6-1. The first shovels were cable operated crane devices, however, these have almost completely been replaced by hydraulic shovels, as shown in Figure 6-2.

\section{Figure 6-1}

Front Shovel Components

(Extracted from Reference 3, p. 50)

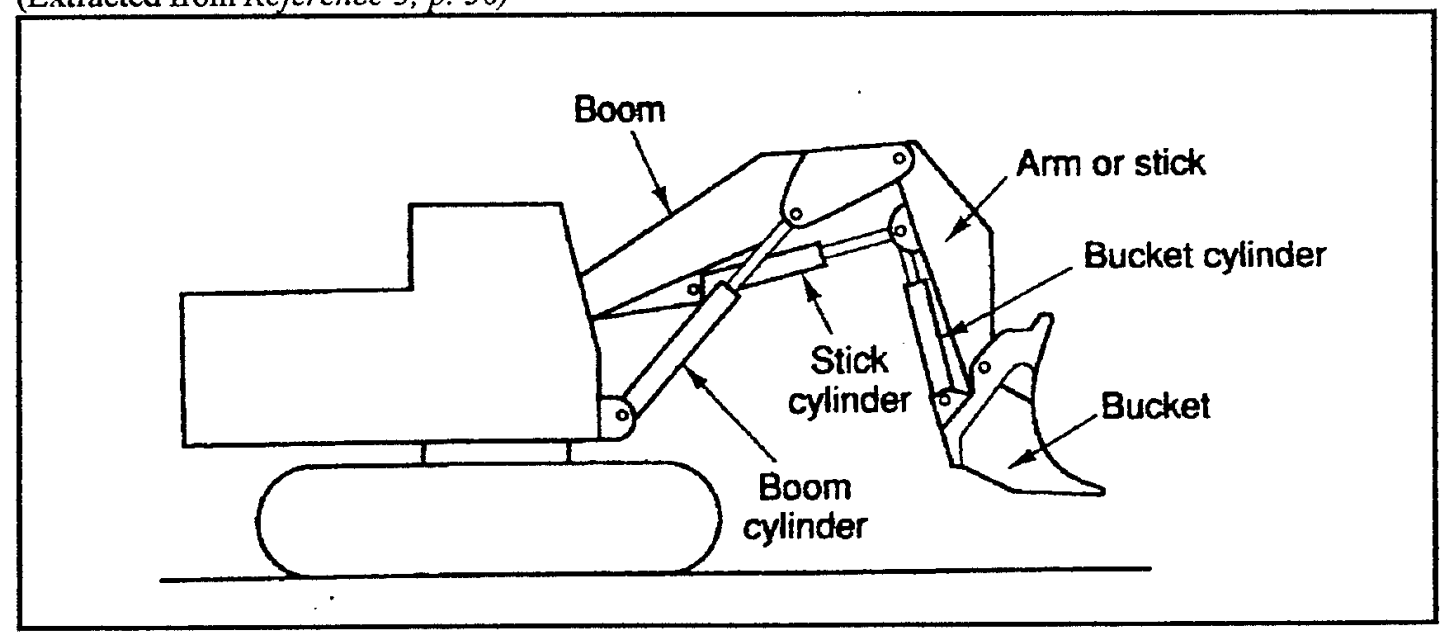


Figure 6-2

Front Shovel

(Courtesy Point 2 Heavy Equipment Exchange)

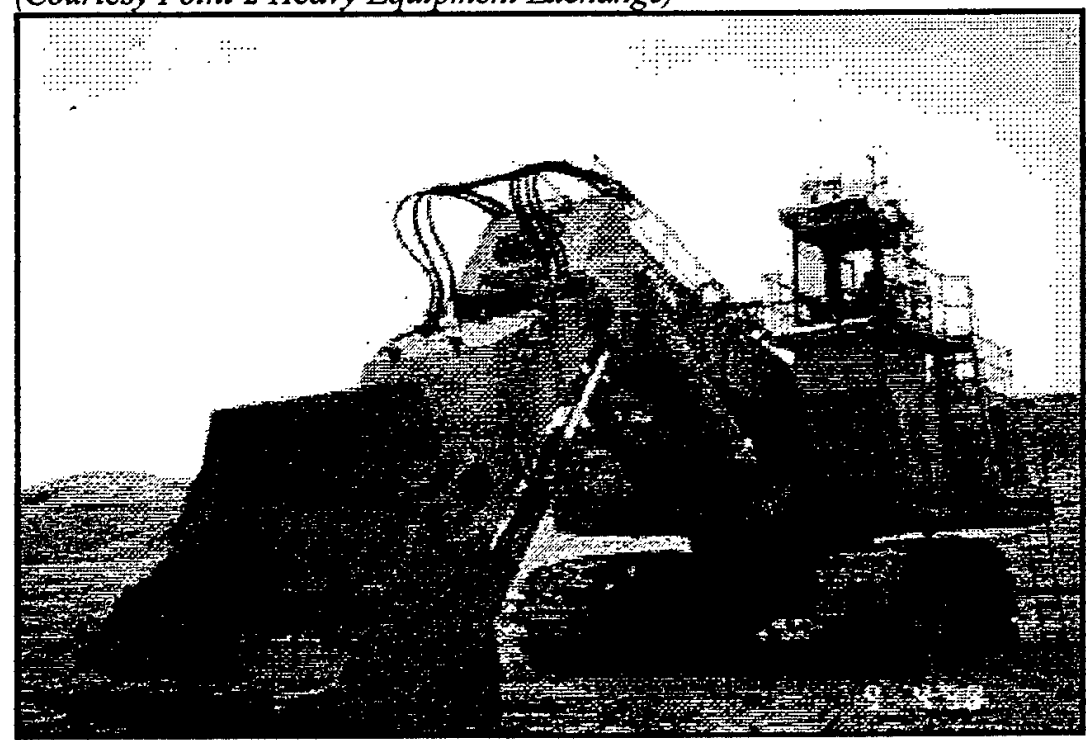

Production for shovels is based on the shovel's ideal productivity. Ideal

productivity would be obtained if the shovel was operated at $100 \%$ efficiency under perfect conditions. This, however, is nearly impossible to obtain. Therefore, the actual production will be the ideal productivity adjusted by various factors.

There are two methods for obtaining ideal productivity. The first method is to obtain the ideal productivity from tables similar to Table 6-2. The second method is a mathematical solution base on the following formula:

\section{Ideal Productivity $=[($ Bucket Capacity $) \times($ Fill Factor $)] \div$ Ideal Cycle Time}

Shovel buckets are rated for heaped capacity, and this rating must be adjusted by a fill factor to account for different soil properties. Table 6-1 lists fill factors for different soil types. Analysis from manufactures data indicates that shovel ideal cycle times fall into the range of 20 to 28 seconds for bottom dump buckets and 22 to 32 seconds for front dump buckets. $^{(6-140)}$

As mentioned previously, the ideal production must be adjusted by factors to account for actual conditions. These factors include: 
- Swing/depth Factor (Table 6-3)

- Efficiency Factor (Table 5-1)

and the actual productivity is given by:

\section{Actual Productivity = Ideal Productivity $\mathbf{x}$ Efficiency Factor $\mathbf{x}$ Swing/depth Factor}

Table 6-1

Bucket Fill Factors For Shovels

\begin{tabular}{lc}
\hline Material & Bucket Fill Factor \\
\hline Bank Clay; earth & $1.00-1.10$ \\
Rock/Earth Mixtures & $1.05-1.15$ \\
Poorly Blasted Rock & $0.85-1.00$ \\
Well Blasted Rock & $1.00-1.10$ \\
Shale; sandstone & $0.85-1.10$ \\
\hline
\end{tabular}

Data for this table was extracted from Reference 6, p. 140

Table 6-2

Ideal Shovel Productivity in Bank Cubic Yards per Hour (BCY/hr)

\begin{tabular}{lllllllll}
\hline \multicolumn{1}{c}{ Bucket Capacity } & $1 / 2 \mathrm{cy}$ & $3 / 4 \mathrm{cy}$ & $1 \mathrm{cy}$ & $11 / 4 \mathrm{cy}$ & $11 / 2 \mathrm{cy}$ & $13 / 4 \mathrm{cy}$ & $2 \mathrm{cy}$ & $2 \mathrm{cy}$ \\
\hline \multicolumn{1}{c}{ Material } & & & & & & & & \\
Moist Loam & 115 & 165 & 205 & 250 & 285 & 320 & 355 & 405 \\
Sand and Gravel & 110 & 155 & 200 & 230 & 270 & 300 & 330 & 390 \\
Common Earth & 95 & 135 & 175 & 210 & 240 & 270 & 300 & 350 \\
Tough Clay & 75 & 110 & 145 & 180 & 210 & 235 & 265 & 310 \\
Well blasted rock & 60 & 95 & 125 & 155 & 180 & 205 & 230 & 275 \\
Earth/rock mixture & 50 & 80 & 105 & 130 & 155 & 180 & 200 & 245 \\
Wet Clay & 40 & 70 & 95 & 120 & 145 & 165 & 185 & 230 \\
Poorly blasted rock & 25 & 50 & 75 & 95 & 115 & 140 & 160 & 195 \\
\hline
\end{tabular}

Data for this table was extracted from Reference $6, p .140$

Table 6-3

Shovel Productivity Correction Factors for Depth of Cut and Angle of Swing

\begin{tabular}{cccccccc}
\hline $\begin{array}{c}\text { \% of Optimum } \\
\text { Depth }\end{array}$ & \multicolumn{7}{c}{$\begin{array}{c}\text { Angle of } \\
\text { Swing }\end{array}$} \\
\hline & $45^{\circ}$ & $60^{\circ}$ & $75^{\circ}$ & $90^{\circ}$ & $120^{\circ}$ & $150^{\circ}$ & $180^{\circ}$ \\
\cline { 2 - 8 } $40 \%$ & 0.93 & 0.89 & 0.85 & 0.80 & 0.72 & 0.65 & 0.59 \\
$60 \%$ & 1.10 & 1.03 & 0.96 & 0.91 & 0.81 & 0.73 & 0.66 \\
$80 \%$ & 1.22 & 1.12 & 1.04 & 0.98 & 0.86 & 0.77 & 0.69 \\
$100 \%$ & 1.26 & 1.16 & 1.07 & 1.00 & 0.88 & 0.79 & 0.71 \\
$120 \%$ & 1.20 & 1.11 & 1.03 & 0.97 & 0.86 & 0.77 & 0.70 \\
$140 \%$ & 1.12 & 1.04 & 0.97 & 0.91 & 0.81 & 0.73 & 0.66 \\
$160 \%$ & 1.03 & 0.96 & 0.90 & 0.85 & 0.75 & 0.67 & 0.62 \\
\hline
\end{tabular}

Data for this table was extracted from Reference $6, p .141$ 


\section{Example 6-1}

A contractor elects to use a bottom dump front excavator with a 1 cubic yard bucket and a 10 feet ideal depth of cut to perform the excavation for a new motel. The average depth of cut for this excavation will be 6 feet. The exccvated material is common earth. The job conditions are excellent, while management conditions are fair. The job site provides for $a 90^{\circ}$ angle of swing. (a) Calculate the actual production of this shovel in BCY's based on an ideal productivity from table 6-2. (b) Calculate the actual production of this shovel in BCY's based on the ideal productivity formula.

\section{Solution}

(a)

Step 1 - Obtain Ideal Productivity (Table 6-2)

\section{With 1 cy bucket and material common earth}

Ideal Productivity $=175 \mathrm{BCY} / \mathrm{hr}$

Step 2 - Determine Efficiency Factor (Table 5-1)

With Fair Management and Excellent Job Conditions

Efficiency Factor $=0.76$

Step 3 - Determine Swing/Depth Factor (Table 6-3)

With $90^{\circ}$ Angle of Swing and 60\% depth of cut $\left(6^{\prime} / 10^{\prime}\right)$

Swing/Depth Factor $=0.91$

Step 4 - Calculate Actual Production

Actual Production = Ideal Production $x$ Efficiency Factor $x$ Swing/Depth Factor

Actual Production $=175 \mathrm{BCY} / \mathrm{hr} \times 0.76 \times 0.91=\underline{121.03 \mathrm{BCY} / \mathrm{hr}}$

(b)

Step 1 - Obtain Ideal Productivity by Formula

With: Bucket Fill Factor $=1.10$ (Table 6-1)

Swell $\quad=25 \%$ (Table 4-1)

Ideal Cycle Time $\quad=20 \mathrm{sec}$ (estimated)

Ideal Productivity $=[$ (Bucket Capacity) $x$ (Fill Factor) $] \div$ Ideal Cycle Time

Ideal Productivity $=[1 \mathrm{LCY} \times 1.10 \times 3600 \mathrm{sec} / \mathrm{hr}] \div[20 \mathrm{sec} \times 1.25 \mathrm{BCY} / \mathrm{LCY}]$ Ideal Productivity $=158.4 \mathrm{BCY} / \mathrm{hr}$

Step 2 - Calculate Actual Production

Actual Production $=158.4 \mathrm{BCY} / \mathrm{hr} \times 0.76 \times 0.91=\underline{109.5 \mathrm{BCY} / \mathrm{hr}}$

Example 6-1 illustrates that different methods may produce slightly different answers. It should also be noted that most manufactures have there own tables of adjustment factors, and the factors will generally differ slightly between manufactures.

\subsection{Backhoes}

Another popular piece of equipment for excavating is the hydraulic backhoe, Figure 6-3. Backhoes can be either wheel mounted or track mounted. Often small wheeled tractors will have a small backhoe attachment, Figure 6-4. For larger excavations 
the backhoe will generally be track mounted. Backhoe components are illustrated on Figure 6-5.

The hydraulic backhoe's production is based on an ideal cycle time adjusted by an efficiency factor (Table 5-1) and a swing/depth factor (Table 6-6). Table 6-5 provides ideal cycle times for backhoes and can be used in developing the actual productivity. The following illustrates the formula for obtaining actual production in $\mathrm{BCY} / \mathrm{hr}$ :

\section{Actual Production $(B C Y / h r)=(C \times S \times V \times B \times E) \div(1+$ swell $)$}

$$
\begin{aligned}
\text { Where C } & =\text { Cycles per hour } \\
\mathrm{S} & =\text { Swing/depth factor } \\
\mathrm{V} & =\text { Bucket volume } \\
\mathrm{B} & =\text { Bucket fill factor } \\
\mathrm{E} & =\text { Job efficiency }
\end{aligned}
$$

\section{Figure 6-3}

Hydraulic Backhoe

(Courtesy M. Adams Equipment Co.)

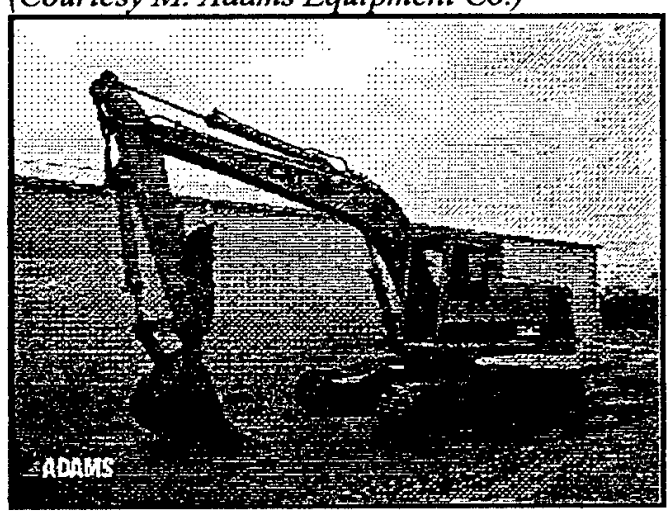

Figure 6-4

Tractor Backhoe

(Courtesy M. Adams Equipment Co.)

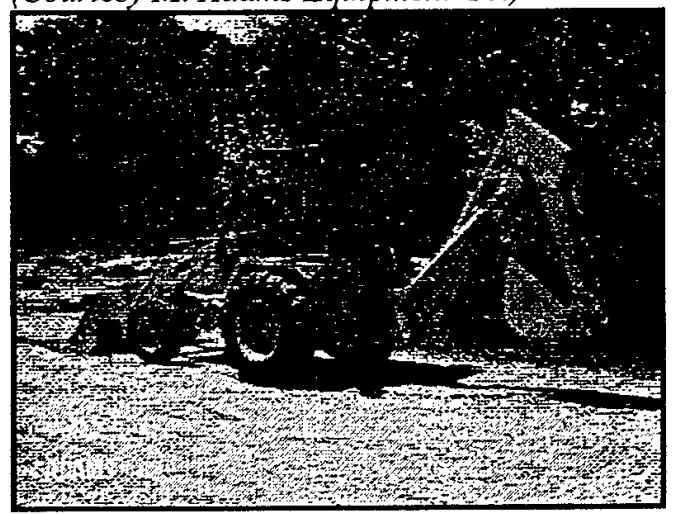


Figure 6-5

Backhoe Components

(Extracted from Reference 3, p. 58)

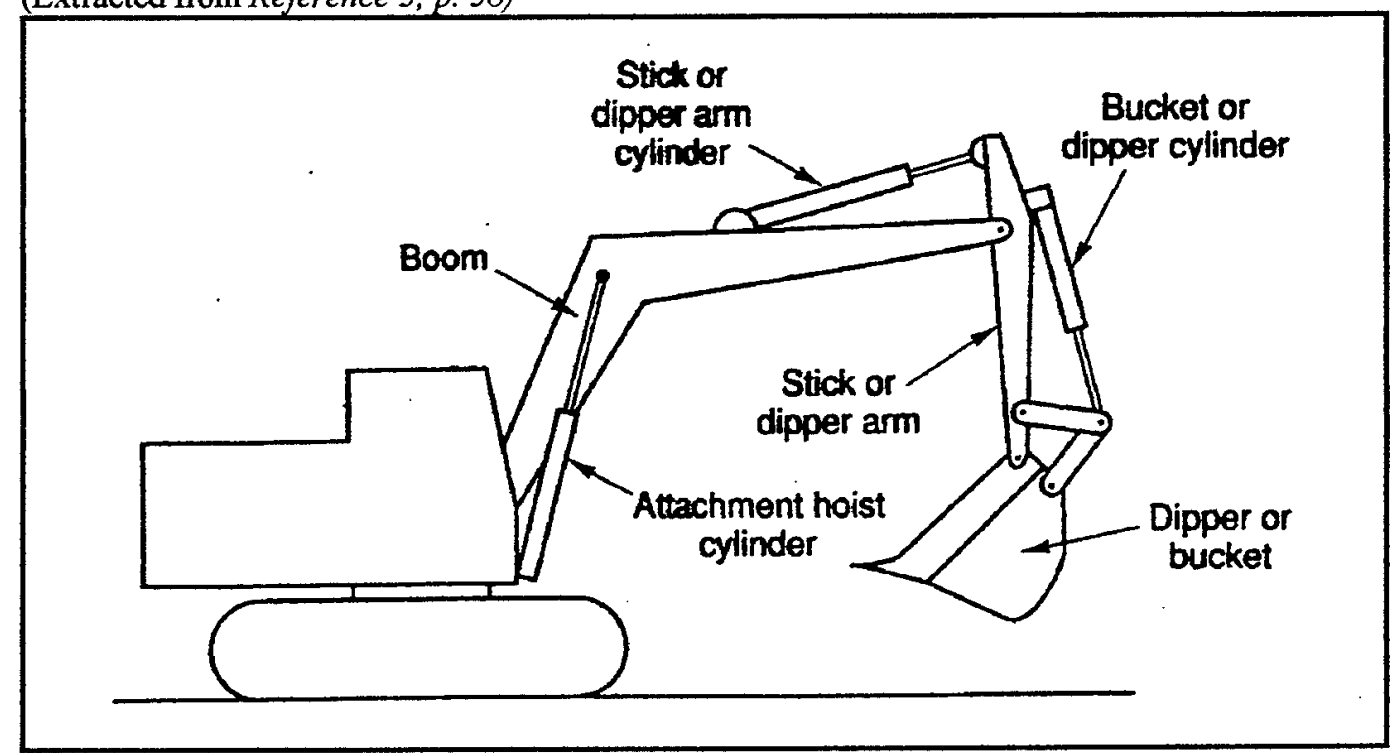

Table 6-4

Bucket Fill Factors For Backhoes

\begin{tabular}{lc}
\hline \multicolumn{1}{c}{ Material } & Bucket Fill Factor \\
\hline Moist Loam or Sandy Clay & $1.00-1.10$ \\
Sand and Gravel & $0.95-1.10$ \\
Hard Tough Clay & $0.80-0.90$ \\
Well Blasted Rock & $0.60-0.75$ \\
Poorly Blasted Rock & $0.40-0.50$ \\
\hline Data for this table was extracted from Reference 6, p. 146
\end{tabular}

Table 6-5

Standard Cycle Time for Hydraulic Backhoes (Cycles per Hour)

\begin{tabular}{|c|c|c|c|c|}
\hline \multirow[b]{2}{*}{ Type of Material } & \multicolumn{3}{|c|}{ Machine Size } & \multirow[b]{2}{*}{$\begin{array}{l}\text { Large Excavator } \\
21 / 2 \text { cy and up }\end{array}$} \\
\hline & $\begin{array}{l}\text { Wheeled } \\
\text { Tractor }\end{array}$ & $\begin{array}{l}\text { Small Excavator } \\
1 \text { cy or less }\end{array}$ & $\begin{array}{c}\text { Medium Excavator } \\
11 / 4-21 / 4 \mathrm{cy}\end{array}$ & \\
\hline Sand, Gravel, Loam & 170 & 250 & 200 & 150 \\
\hline $\begin{array}{l}\text { Common Earth, } \\
\text { Sandy Clays }\end{array}$ & 135 & 200 & 160 & 120 \\
\hline Hard Clays \& Rock & 110 & 160 & 130 & 100 \\
\hline
\end{tabular}

Data for this table was extracted from Reference 3, p. 59 


\section{Table 6-6}

Swing Depth Factors for Backhoes

\begin{tabular}{ccccccc}
\hline & \multicolumn{7}{c}{ Angle of } & Swing (deg) \\
\cline { 2 - 7 } $\begin{array}{c}\text { Depth of Cut } \\
\text { (\% of Max) }\end{array}$ & $\mathbf{4 5}$ & $\mathbf{6 0}$ & $\mathbf{7 5}$ & $\mathbf{9 0}$ & $\mathbf{1 2 0}$ & $\mathbf{1 8 0}$ \\
\hline $\mathbf{3 0}$ & $\mathbf{1 . 3 3}$ & 1.26 & 1.21 & 1.15 & 1.08 & 0.95 \\
$\mathbf{5 0}$ & 1.28 & 1.21 & 1.16 & 1.10 & 1.03 & 0.91 \\
$\mathbf{7 0}$ & 1.16 & 1.10 & 1.05 & 1.00 & 0.94 & 0.83 \\
$\mathbf{9 0}$ & 1.04 & 1.00 & $\mathbf{0 . 9 5}$ & 0.90 & 0.85 & 0.75 \\
\hline
\end{tabular}

Data for this table was extracted from Reference 3, p. 60

\section{Example 6-1}

A contractor is excovating for a residential foundation \& slab with a small wheeled tractor backhoe with a $1 / 4$ cy bucket. The backhoe has a maximum depth of cut of 8'. The Material being excavated is sand, and the average depth of the excavation is 3'. The backhoe will be required to swing $75^{\circ}$ to dump. What is the actual productivity of this backhoe in BCY/hr if it works 50 mimutes/hr?

\section{Solution}

$$
\begin{aligned}
& \text { Step } 1 \text { - Calculate Actual Productivity } \\
& \text { With: Bucket Fill Factor (B) } \quad=1.10 \text { (Table 6-4) } \\
& \text { Swell } \quad=12 \% \text { (Table 4-1) } \\
& \text { Standard Cycles (C) } \quad=170 \text { cycles/hr (Table 6-5) } \\
& \text { Bucket (V) } \quad=1 / 4 \mathrm{cy} \\
& \text { Swing/Depth Factor (S) } \quad=1.19 \text { (Interpolate from Table 6-6) } \\
& \text { Efficiency Factor }(E) \quad=.83(50 / 60)^{*} \\
& \text { Actual Production }(B C Y / h r)=(C \times S \times V \times B \times E) \div(1+\text { swell }) \\
& \text { Actual Production }(B C Y / h r)=(170 \times 1.19 \times .25 \times 1.1 \times .83) \div 1.12 \\
& \text { Actual Production }=\underline{41.2 \mathrm{BCY} / \mathrm{hr}}
\end{aligned}
$$

*Remember, you use either a given number of mimutes worked per hour as the efficiency factor or you obtain an efficiency factor from table 5-1, but you don't use both on the same problem!

Hydraulic backhoes are often used to excavate trenches. Because trenches tend to cave in, some of the excavation time is wasted removing this cave in material. Therefore, Table 6-7 provides trench adjustment factors that should be used when calculating trenching production. 
Table 6-7

Adjustment Factor for Trench Production

\begin{tabular}{cc}
\hline Type of Material & Adjustment Factor \\
\hline Sand, Gravel, Loam & $0.60-0.70$ \\
Common Earth & $0.90-0.95$ \\
Firm Plastic Soils & $0.95-1.00$ \\
\hline
\end{tabular}

Data for this table was extracted from Reference 3, p. 60

\subsection{Draglines}

Draglines have the advantage of superior reach and depth capabilities over their counterparts, the shovel and backhoe. Draglines perform their excavation cycle by simply dragging a bucket across the surface of the area to be excavated. The dragline relies on the weight of the bucket to provide its digging action. They do not have the same lateral support of a shovel or backhoe, and this will sometimes result in the dragline's bucket twisting or skipping. Because of their superior reach and depth, draglines are well suited for dredging and stockpiling operations. An illustration of the dragline's components is shown in Figure 6-6. An example of a dragline is shown in Figure 6-7. 
Figure 6-6

Dragline Components

(Extracted from Reference 3, p. 53)

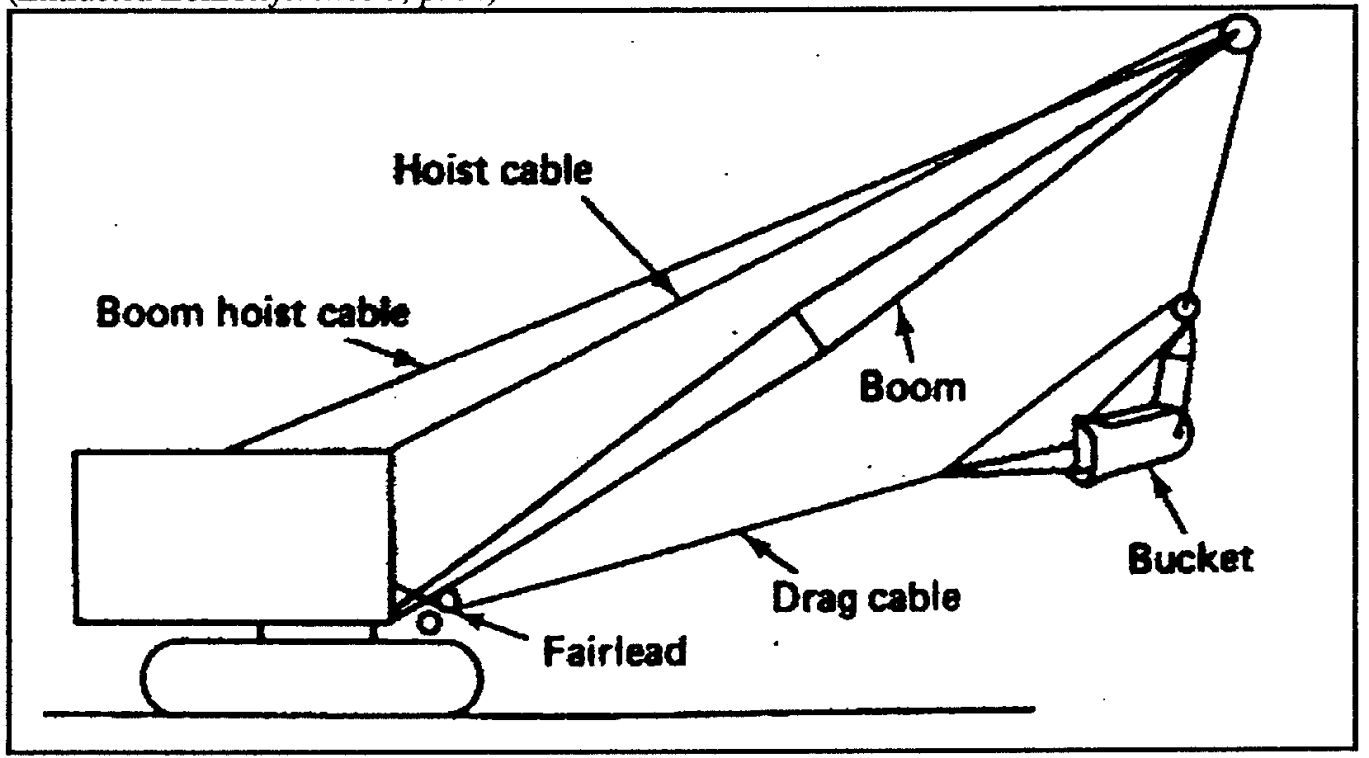

Figure 6-7

Dragline

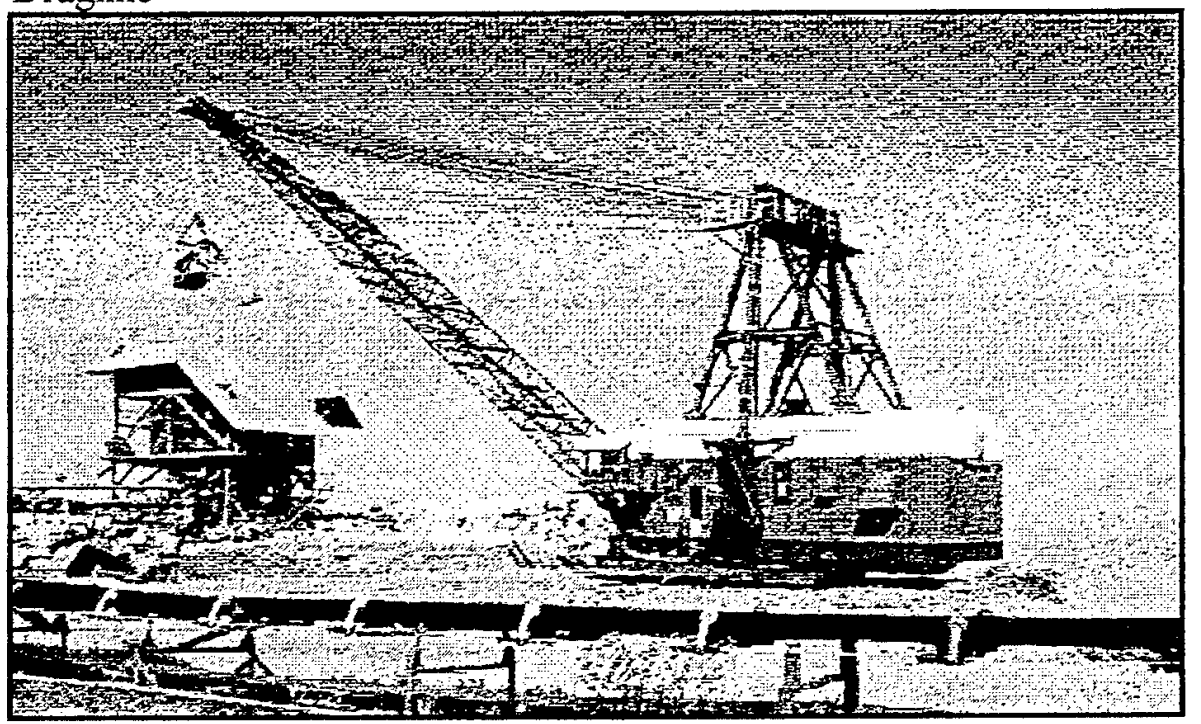

Production for draglines is based on the dragline's ideal productivity. The draglines ideal productivity will be adjusted by efficiency factors (Table 5-1) and swing depth factors (Table 6-10) to obtain the actual productivity. 
Table 6-8

Ideal Dragline Production in Bank Cubic Yards per Hour (BCY/hr)

\begin{tabular}{lcccccccc}
\hline Bucket Capacity & $3 / 4 \mathrm{cy}$ & $1 \mathrm{cy}$ & $11 / 4 \mathrm{cy}$ & $11 / 2 \mathrm{cy}$ & $13 / 4 \mathrm{cy}$ & $2 \mathrm{cy}$ & $21 / 2 \mathrm{cy}$ & $3 \mathrm{cy}$ \\
\hline $\begin{array}{c}\text { Material Type } \\
\text { Moist Loam; }\end{array}$ & & & & & & & & \\
Light Sandy Clay & 130 & 160 & 195 & 220 & 245 & 265 & 305 & 350 \\
Sand and Gravel & 125 & 155 & 185 & 210 & 235 & 255 & 295 & 340 \\
Common Earth & 105 & 135 & 165 & 190 & 210 & 230 & 265 & 305 \\
Hard, tough clay & 90 & 110 & 135 & 160 & 180 & 195 & 230 & 270 \\
Wet, sticky clay & 55 & 75 & 95 & 110 & 130 & 145 & 175 & 210 \\
\hline
\end{tabular}

Data for this table was extracted from Reference $6, p .152$

Table 6-9

Optimum Depth of Cut for Various Dragline Bucket Sizes (in feet)

\begin{tabular}{lcccccccc}
\hline Bucket Capacity & $1 / 2 \mathrm{cy}$ & $3 / 4 \mathrm{cy}$ & $1 \mathrm{cy}$ & $11 / 4 \mathrm{cy}$ & $11 / 2 \mathrm{cy}$ & $13 / 4 \mathrm{cy}$ & $2 \mathrm{cy}$ & $21 / 2 \mathrm{cy}$ \\
\hline \multicolumn{1}{l}{ Material Type } & & & & & & & & \\
Moist Loam; & & & & & & & & \\
Light Sandy Clay & 5.5 & 6.0 & 6.6 & 7.0 & 7.4 & 7.7 & 8.0 & 8.5 \\
Sand and Gravel & 5.5 & 6.0 & 6.6 & 7.0 & 7.4 & 7.7 & 8.0 & 8.5 \\
Common Earth & 6.7 & 7.4 & 8.0 & 8.5 & 9.0 & 9.5 & 9.9 & 10.5 \\
Hard, tough clay & 8.0 & 8.7 & 9.3 & 10.0 & 10.7 & 11.3 & 11.8 & 12.3 \\
Wet, sticky clay & 8.0 & 8.7 & 9.3 & 10.0 & 10.7 & 11.3 & 11.8 & 12.3 \\
\hline
\end{tabular}

Data for this table was extracted from Reference 6, p. 153

Table 6-10

Dragline Productivity Correction Factors for Depth of Cut \& Angle of Swing

\begin{tabular}{ccccccccc}
\hline $\begin{array}{c}\text { \% of Optimum } \\
\text { Depth }\end{array}$ & \multicolumn{7}{c}{$\begin{array}{c}\text { Angle of } \\
\text { Swing }\end{array}$} \\
\hline & $30^{\circ}$ & $45^{\circ}$ & $60^{\circ}$ & $75^{\circ}$ & $90^{\circ}$ & $120^{\circ}$ & $150^{\circ}$ & $180^{\circ}$ \\
\hline & 1.06 & 0.99 & 0.94 & 0.09 & 0.87 & 0.81 & 0.75 & 0.70 \\
$40 \%$ & 1.17 & 1.08 & 1.02 & 0.97 & 0.93 & 0.85 & 0.78 & 0.72 \\
$60 \%$ & 1.25 & 1.13 & 1.06 & 1.01 & 0.97 & 0.88 & 0.80 & 0.74 \\
$80 \%$ & 1.29 & 1.17 & 1.09 & 1.04 & 0.99 & 0.90 & 0.82 & 0.76 \\
$100 \%$ & 1.32 & 1.19 & 1.11 & 1.05 & 1.00 & 0.91 & 0.83 & 0.77 \\
$120 \%$ & 1.29 & 1.17 & 1.09 & 1.03 & 0.98 & 0.90 & 0.82 & 0.76 \\
$140 \%$ & 1.25 & 1.14 & 1.06 & 1.00 & 0.96 & 0.88 & 0.81 & 0.75 \\
$160 \%$ & 1.20 & 1.10 & 1.02 & 0.97 & 0.93 & 0.85 & 0.79 & 0.73 \\
$180 \%$ & 1.15 & 1.05 & 0.98 & 0.94 & 0.90 & 0.82 & 0.76 & 0.71 \\
$200 \%$ & 1.10 & 1.00 & 0.94 & 0.90 & 0.87 & 0.79 & 0.73 & 0.69 \\
\hline
\end{tabular}

Data for this table was extracted from Reference 6, p. 153

\section{Example 6-2}

A dragline with a 2 cubic yard bucket will be used to excavate for a landfill. The contractor estimates the total volume of the excavation to be 1,500,000 cubic yards of sandy clay. The average depth of excavation will be 15'. The dragline will be operating through a swing of $120^{\circ}$. Job management is good and job conditions are fair. Based on 
this information what will the actual production be in bank cubic yards per hour (BCY/hr)? Additionally, what will the expected duration be for this excavation?

\section{Solution}

Step 1 - Calculate Ideal Production

Ideal Production $=265 \mathrm{BCY} / \mathrm{hr}($ Table 6-8)

Step 2 - Calculate Swing/depth Factor

Optimum depth of cut $=8.0^{\prime}$ (Table 6-9)

$\%$ of Optimum $=15^{\prime} / 8^{\prime} \times 100=187.5 \%$

Swing $=120^{\circ}$

Swing/depth Factor $=0.81$ (Table 6-10)

Step 3 - Calculate Efficiency Factor

$$
\text { Efficiency Factor }=0.69 \text { (Table 5-1) }
$$

Step 4 - Calculate Actual Production

Actual Productivity = Ideal Productivity $x$ Efficiency Factor $x$ Swing/depth Factor Actual Productivity $=265 B C Y / h r \times 0.69 \times 0.81$ Actual Productivity $=\underline{148.1 \mathrm{BCY} / \mathrm{hr}}$

Step 5 - Calculate Duration

Duration $=$ Quantity of Excovation $\div$ Actual Production

Duration $=1,500,000 \div 148.1 \mathrm{BCY} / \mathrm{hr}$

Duration $=10,128.3$ hrs, or 422 davs 


\section{Tractors/Dozers}

Tractors/dozers are a common sight on most construction sites. They are of two variants, either wheel type (Figure 7-1) or track type (Figure 7-2). Some common uses of tractors/dozers include:

- Backfilling

- Clearing \& grubbing

- Creating stockpiles

- Excavating

- Slope shaping

- Spreading materials

- Towing

- Rough grading

There are many ways to calculate tractor/dozer production. Some methods include calculating theoretical blade capacity coupled with equipment cycle time and other factors. However, equipment manufactures generally have production charts, similar to Figure 7-3, for aiding the equipment manager in estimating production. These production estimating charts combined with the correction factors provided in Table 7-1 will provide the basis for evaluating tractor/dozer production here.

\section{Figure 7-1}

Wheel Type Dozer

(Courtesy Caterpillar)

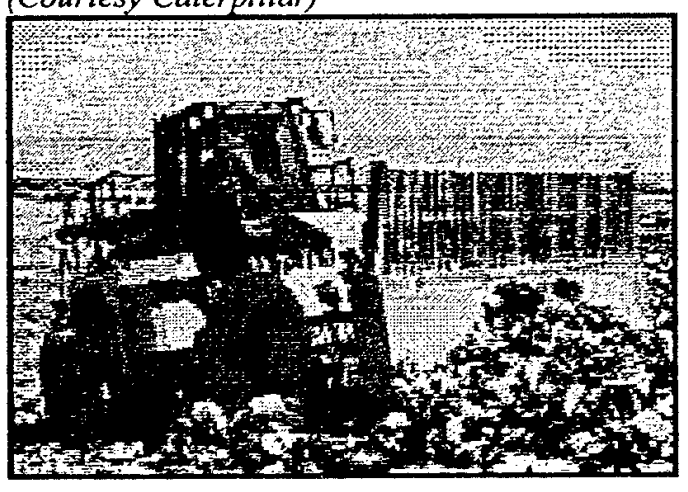

\section{Figure 7-2}

Track Type Dozer

(Courtesy M. Adams Equipment Co.)

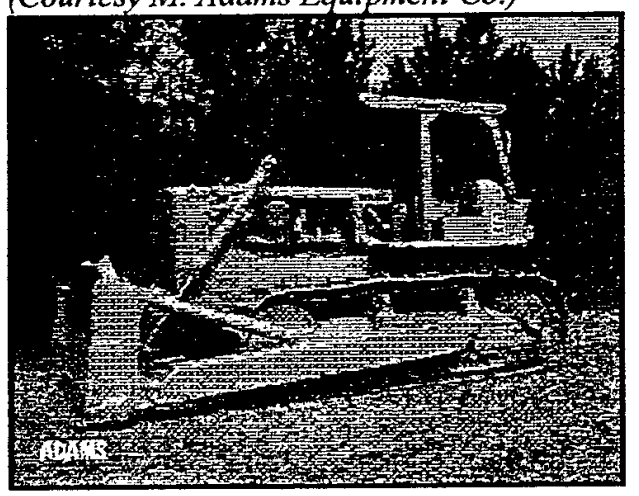


Figure 7-3

Estimated Dozing Production

(Extracted from Reference 1, p.113)

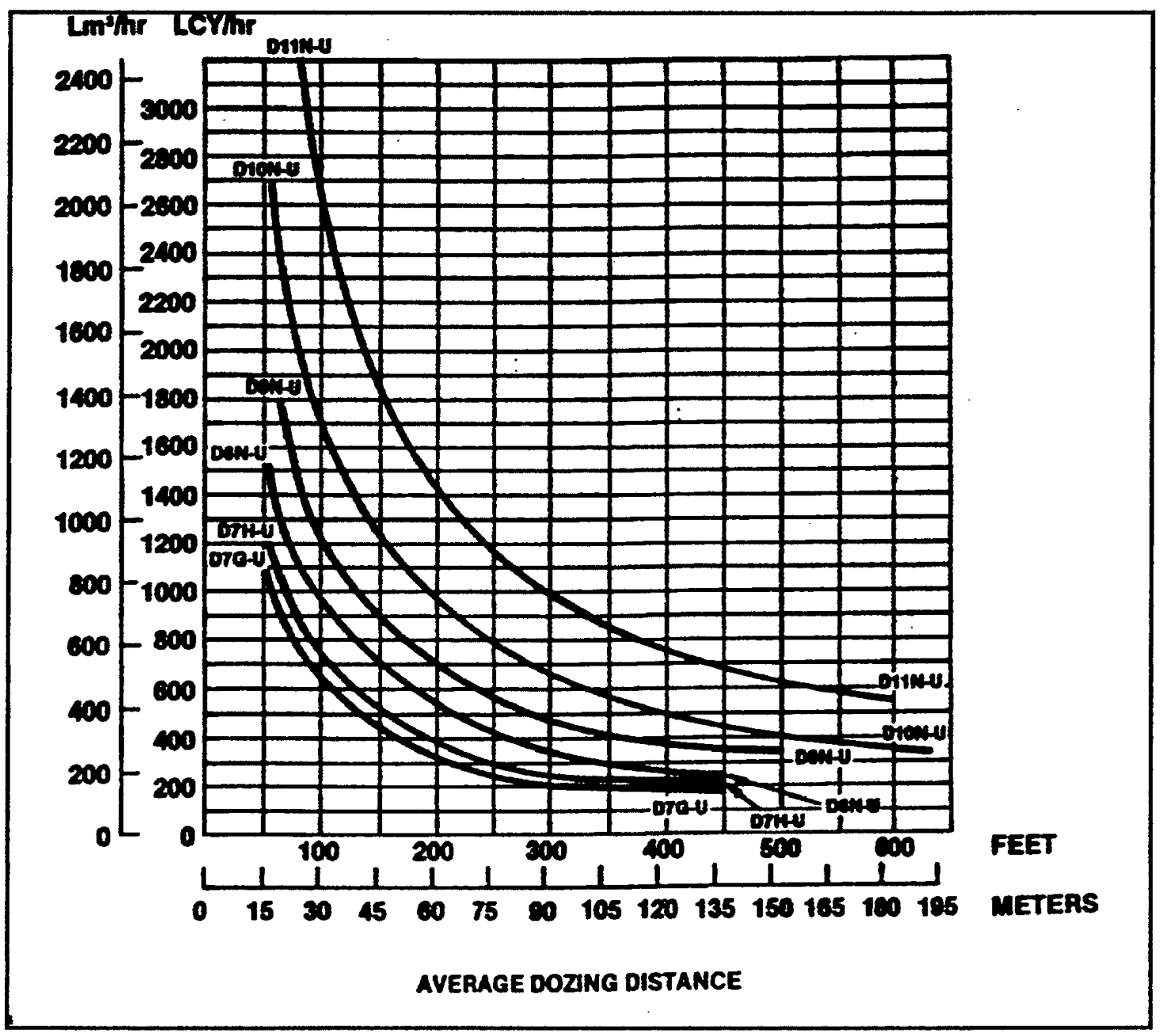


Table 7-1

Dozing Correction Factors

\begin{tabular}{|c|c|c|}
\hline Job Condition Corrections & Track Type Tractor/Dozer & Wheel Type Tractor/Dozer \\
\hline \multicolumn{3}{|l|}{ Operator } \\
\hline Excellent & 1.00 & 1.00 \\
\hline Average & 0.75 & 0.60 \\
\hline Poor & 0.60 & 0.50 \\
\hline \multicolumn{3}{|l|}{ Material } \\
\hline Loose stockpile & 1.20 & 1.20 \\
\hline \multicolumn{3}{|l|}{ Hard to cut; frozen } \\
\hline with tilt cylinder & 0.80 & 0.75 \\
\hline without tilt cylinder & 0.70 & $\mathbf{n} / \mathbf{a}$ \\
\hline cable-controlled blade & 0.60 & $\mathbf{n} / \mathbf{a}$ \\
\hline $\begin{array}{l}\text { Hard to drift material } \\
\text { (dry, non-cohesive or very sticky) }\end{array}$ & 0.80 & 0.80 \\
\hline Rock, ripped or blasted & $0.60-0.80$ & $\mathbf{n} / \mathbf{a}$ \\
\hline Slot Dozing & 1.20 & 1.20 \\
\hline Side by side dozing & $1.15-1.25$ & $1.15-1.25$ \\
\hline Visibility (dust, snow, and so on) & 0.80 & 0.70 \\
\hline Direct Drive Transmission & 0.80 & $\mathbf{n} / \mathbf{a}$ \\
\hline \multicolumn{3}{|l|}{ Grades } \\
\hline$-30 \%$ & 1.6 & 1.6 \\
\hline$-20 \%$ & 1.4 & 1.4 \\
\hline$-10 \%$ & 1.2 & 1.2 \\
\hline \multicolumn{3}{|l|}{ unfavorable } \\
\hline$+10 \%$ & 0.73 & 0.73 \\
\hline$+20 \%$ & 0.50 & 0.50 \\
\hline$+30 \%$ & 0.27 & 0.27 \\
\hline
\end{tabular}

Data for this table was extracted from Reference 1, p. 114

Assumptions made in the above table include:

- $60 \mathrm{~min} / \mathrm{hr}$ efficiency

- Fixed cycle time $=0.05 \mathrm{~min}$

- Material dumped over a wall

- Load factor $=0.76$

- Hydraulically controlled blade

- First gear forward for digging

- Second gear reverse for return
- Power shift transmission

- Dozer cuts 50' \& drift remaining distance

- Soil unit weight is $2300 \mathrm{lb}$ per LCY

- Coefficients of traction tracked 0.5 or better

- Coefficients of traction wheeled 0.45 or better

- Second gear forward for carrying

\section{Example 7-1}

A DIIN-U Dozer with a universal blade is used to move dry non-cohesive sand with a unit weight of $2800 \mathrm{lb} / \mathrm{LCY}$ down a $20 \%$ average grade for 100 feet. The owner considers his operator to be excellent, and expects an efficiency of 50 mimutes per hour. What is the expected production of this dozer in LCY/hr?

\section{Solution}

Step 1 - Calculate maximum dozer production

$$
\text { Moximum Production }=\underline{2700 ~ L C Y / h r} \text { (Fig 7-3) }
$$


Step 2 - Determine applicable correction factors (Table 7-1)

Excellent operator $=1.00$

Non-cohesive sand $=0.80$

Grade of $-20 \% \quad=1.40$

Weight correction $\quad=0.82(2300 / 2800$, see assumptions for Table 7-1)

Efficiency $\quad=0.83$

Step 3 - Calculate expected production

Expected Production $=$ Maximum Production $x$ Correction Factors

Expected Production $=2700 \times 1.00 \times 0.80 \times 1.40 \times 0.82 \times 0.83$

Expected Production $=\underline{2058.1 \mathrm{LCY} / \mathrm{hr}}$ 


\section{Loaders}

There are two basic types of loaders; wheel type (Figure 8-1) and track type (Figure 8-2). Both are generally equipped with a bucket ranging in size from one cubic yard to four cubic yards. The maneuverability of loaders makes them extremely useful on a job site. Loaders can be employed in the following tasks:

- Excavation (soft to medium hard material)

- Loading hoppers

- Loading haul units

- Stockpiling material

- Backfilling

- Moving construction materials \& concrete

Loader cycle time is based on basic cycle time, travel time, and correction factors.

Table 8-1 list basic cycle times for various loaders, while Figures 8-3 and 8-4 provide graphs of travel time for wheel type and track type loaders respectively. Table 8-2 provides correction factors for various conditions. The equation for calculating cycle time is:

\section{Loader Cycle Time $=\mathrm{BC}+\mathrm{TT}+\mathrm{CF}$}

Where $\mathrm{BC}=$ Basic Cycle Time $(\mathrm{min})$

$\mathrm{TT}=$ Travel Time $(\mathrm{min})$

$\mathrm{CF}=$ Correction Factors $(\mathrm{min})$

Figure 8-1

Wheel type loader

(Courtesy M. Adams Equipment Co.)

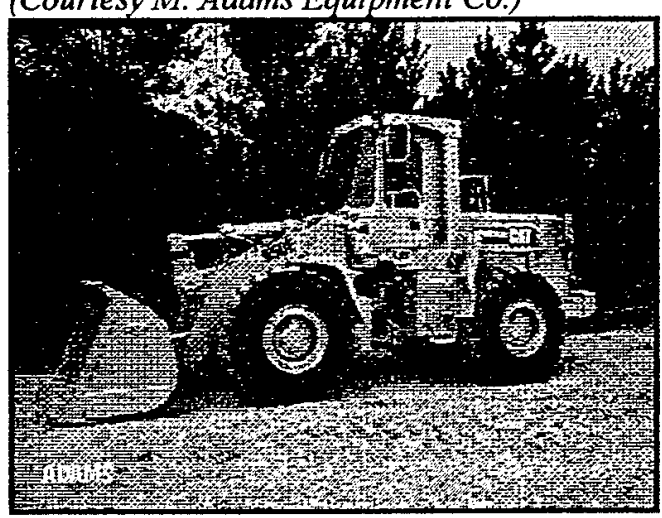

Figure 8-2

Track type loader

(Courtesy M. Adams Equipment Co.)

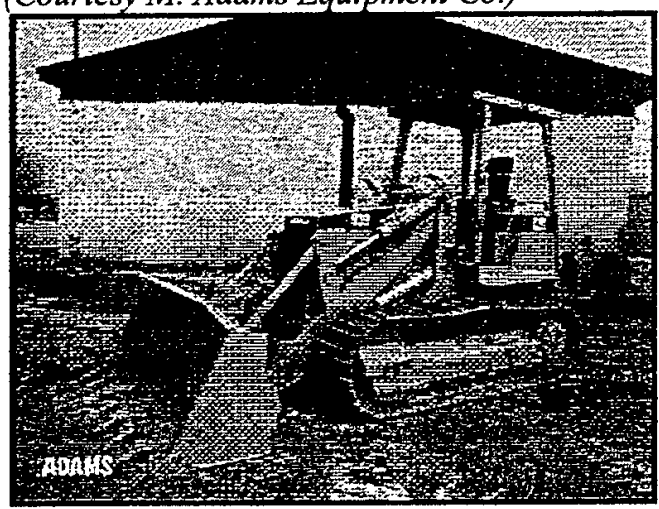


Figure 8-3

Wheel loader travel time

(Extracted from Reference 4, p. 52)

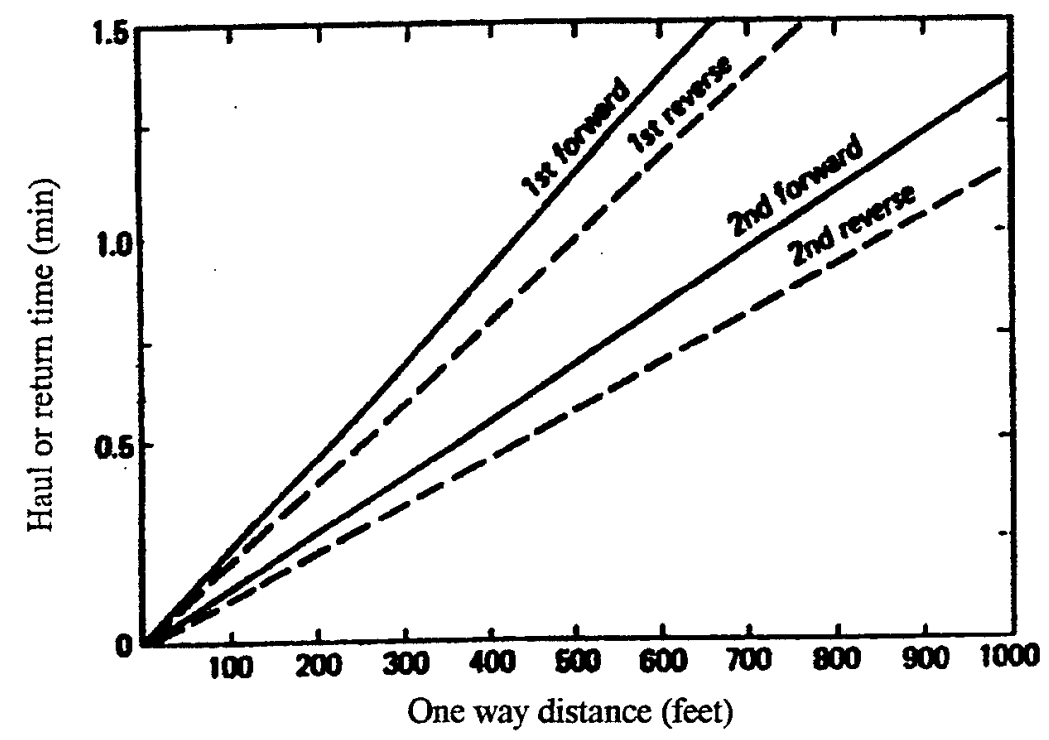

Figure 8-4

Track loader travel time

(Extracted from Reference 4, p. 56)

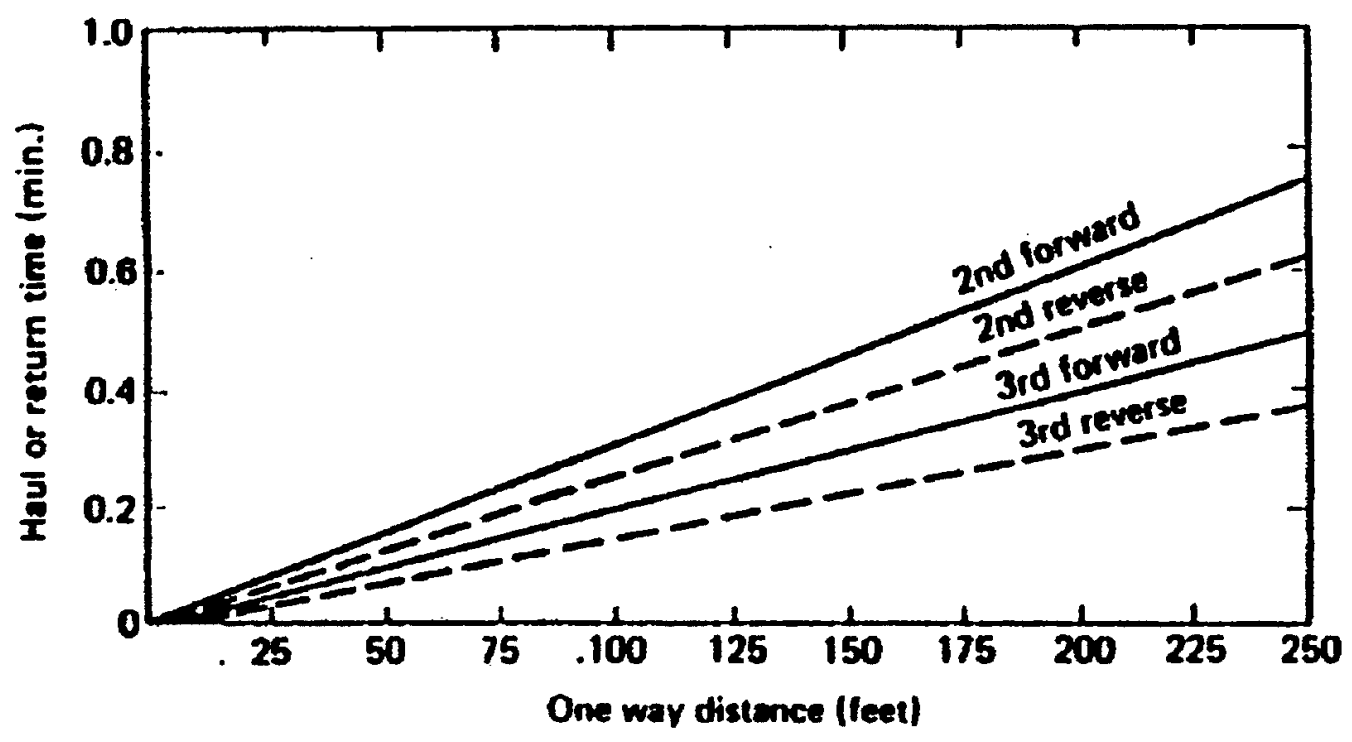


Table 8-1

Loader Basic Cycle Time

\begin{tabular}{lcc}
\hline & \multicolumn{2}{c}{ Basic Cycle Time $(\min )$} \\
\cline { 2 - 3 } Loading Conditions & Wheel Loader & Track Loader \\
\hline Loose Materials & 0.35 & 0.30 \\
Average Material & 0.50 & 0.35 \\
Hard Material & 0.65 & 0.45 \\
\hline
\end{tabular}

Data for this table was extracted from Reference 3, p. 104

Table 8-2

Loader Correction Factors (minutes)

\begin{tabular}{lc}
\hline \multicolumn{1}{c}{ Element } & $\begin{array}{c}\text { Correction Factor } \\
\text { (add to basic cycle time) }\end{array}$ \\
\hline Material & 0.01 to 0.03 \\
Common Earth (loam) & 0.00 to 0.02 \\
Mixed Aggregates & 0.00 to -0.02 \\
Uniform Aggregates: & 0.00 \\
0 to $3 / 4$ in. & 0.03 to 0.16 \\
$3 / 4$ to 6 in & 0.01 to 0.16 \\
Over 6 in & 0.06 to 0.16 \\
Soil with boulders and roots & \\
Cemented materials & \\
& 0.01 \\
Loading Conditions & 0.00 \\
Stockpile, under 10 ft high & 0.02 \\
Stockpile, over 10 ft & 0.04 \\
Dumped by truck & \\
Bank & \\
Operating Conditions & \\
Inconsistent operations & 0.02 to 0.04 \\
Small or fragile target & 0.02 to 0.05 \\
Independently owned trucks & 0.02 to 0.04 \\
\hline Data for this table was extracted from Reference $4, p .53$
\end{tabular}

Loader production is calculated based on cycle time, and the loaders bucket capacity. Bucket capacity is adjusted by bucket fill factors shown in Table 8-3. The equation for calculating production is as follows:

\section{Loader Production $=($ Bucket Capacity $x$ FF $\times$ EF $) \div$ LC}

$$
\text { Where } \begin{aligned}
\text { FF } & =\text { Fill Factor } \\
\mathrm{EF} & =\text { Efficiency Factor }(\mathrm{min} / \mathrm{hr}) \\
\mathrm{LC} & =\text { Loader Cycle }(\mathrm{min})
\end{aligned}
$$


Table 8-3

Loader bucket fill factors

\begin{tabular}{lc}
\hline \multicolumn{1}{c}{ Material } & Fill Factor \\
\hline Mixed or uniform granular & $0.95-1.00$ \\
Medium, coarse stone & $0.85-0.90$ \\
Well blasted rock & $0.80-0.95$ \\
Average blasted rock & $0.75-0.90$ \\
Poorly blasted rock & $0.60-0.75$ \\
Rock dirt mixtures & $1.00-1.20$ \\
Moist loam & $1.00-1.10$ \\
Cemented materials & $0.85-0.95$ \\
\hline
\end{tabular}

Data for this table was extracted from Reference 6, p. 108

\section{Example 8-1}

A track loader with a 3 cubic yard bucket is used to move mixed aggregate form an 8' stockpile to a customer's truck. The distance from the stockpile to the truck is 75', and $2^{\text {nd }}$ gear forward is used when traveling with a full bucket, and $3^{\text {rd }}$ gear forward when returning. The loader works at an efficiency of $50 \mathrm{~min} / \mathrm{hr}$. What is the estimated production of the loader?

Solution

Step I - Calculate Loader Cycle Time

Loader Cycle Time $=B C+T T+C F$

$B C=0.30($ Table 8-1)

$T T=0.23$ for $+0.13 \mathrm{rev}=\underline{0.36} \min ($ Fig $8-4)$

$C F=0.02+0.01+0.03=\underline{0.06} \min ($ Table $8-2)$

Loader Cycle Time $=0.30+0.36+0.06=\underline{0.72} \mathrm{~min}$

Step 2 - Calculate Loader Production

Loader Production $=($ Bucket Capacity $x F F x E F) \div L C$

Loader Production $=(3 c y \times 0.95 \times 50 \mathrm{~min} / \mathrm{hr}) / 0.72 \mathrm{~min}$

Loader Production $=\underline{197.9 \mathrm{LCY} / \mathrm{hr}}$ 


\section{Hauling Equipment}

In estimating hauling equipment cycle times and production it is import to consider some additional factors. These factors include the equipment's rolling resistance, grade resistance, and effective grade. The total resistance of a piece of equipment will be:

\section{Total Resistance $=$ Rolling Resistance + Grade Resistance}

Resistance is typically expressed in pounds per ton of vehicle weight (lb/ton) or in pounds (lb's) only. For the purposes of this report, resistance factors will carry the unit of $1 \mathrm{~b} / \mathrm{ton}$ and resistance will carry the unit of $\mathrm{lb}$ 's.

\subsection{Rolling Resistance}

Rolling resistance is primarily a factor of the resistance incurred from tire flexing and penetration of tires into the surface being traversed. It has been shown that a vehicle traveling over a hard surface roadway will have a rolling resistance factor of about 40 $\mathrm{lb} /$ ton of vehicle weight, and this will increase by $30 \mathrm{lb} /$ ton of vehicle weight for each inch of tire surface penetration. This leads to the following equation for rolling resistance factor:

\section{Rolling Resistance Factor $(\mathrm{lb} / \mathrm{ton})=\mathbf{4 0}+(30 \times$ Inches of tire penetration $)$}

Table 9-1 provides a list of some typical values of rolling resistance factors.

Table 9-1

Typical Values of Rolling Resistance Factors

\section{Type of Surface}

Concrete or Asphalt

Firm, smooth, flexing slightly under load

Rutted dirt roadway, 1-2 inches penetration

Soft, rutted dirt, 3-4 inches penetration

Loose sand or gravel

Soft, muddy, deeply rutted

*Values in parenthesis are for radial tires

Data for this table was extracted from Reference 3, p. 84
Rolling Resistance Factor (lb/ton)

$40(30)^{*}$

$64(52)^{*}$

100

150

200

$300-400$ 


\subsection{Grade Resistance}

Grade resistance results from resistance encountered as a result of positive or negative grades. Grade resistance is that component of resistance acting parallel to the grade. The actual grade resistance can be obtained by multiplying the sine of the angle of grade with respect to horizontal by the vehicles weight. However, because the grades in construction are typically small, it is generally accepted that $1 \%$ of grade will have a grade resistance of $1 \%$ of a vehicles weight. This corresponds to a grade resistance factor of $20 \mathrm{lb} /$ ton for each $1 \%$ of grade, or:

\section{Grade Resistance Factor (lb/ton) $=20 \times$ grade (\%) \\ Grade Resistance (lb) = Vehicle wight (tons) x Grade Resistance Factor (Ib/ton)}

\subsection{Effective Grade}

Effective grade is a simple method of representing the sum of rolling resistance and grade resistance. Effective grade is important because it is often used in equipment manufactures performance charts for estimating equipment performance parameters. Effective grade is the method that will be demonstrated in this paper. The equation for effective grade is given by:

\section{Effective Grade $=$ Grade $(\%)+[$ Rolling Resistance Factor $($ lb/ton $) \div 20]$}

\subsection{Scrapers}

A scraper is a single piece of equipment that has the ability to excavate, load, haul, and dump. There are a number of different scraper types including:

- Single Engine Overhung

- Three Axle

- Twin Engine, All Wheel Drive (Figure 9-1)

- Elevating (Figure 9-2)

- Push Pull 
Figure 9-1

Twin Engine, All Wheel Drive Scraper

(Courtesy M. Adams Equipment Co.)

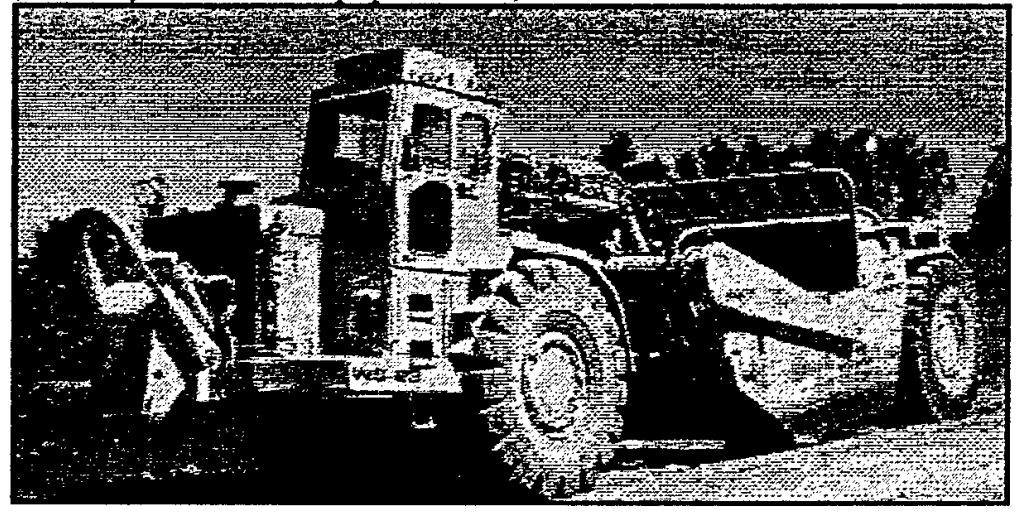

Figure 9-2

Elevating Scraper

(Courtesy M. Adams Equipment Co.)

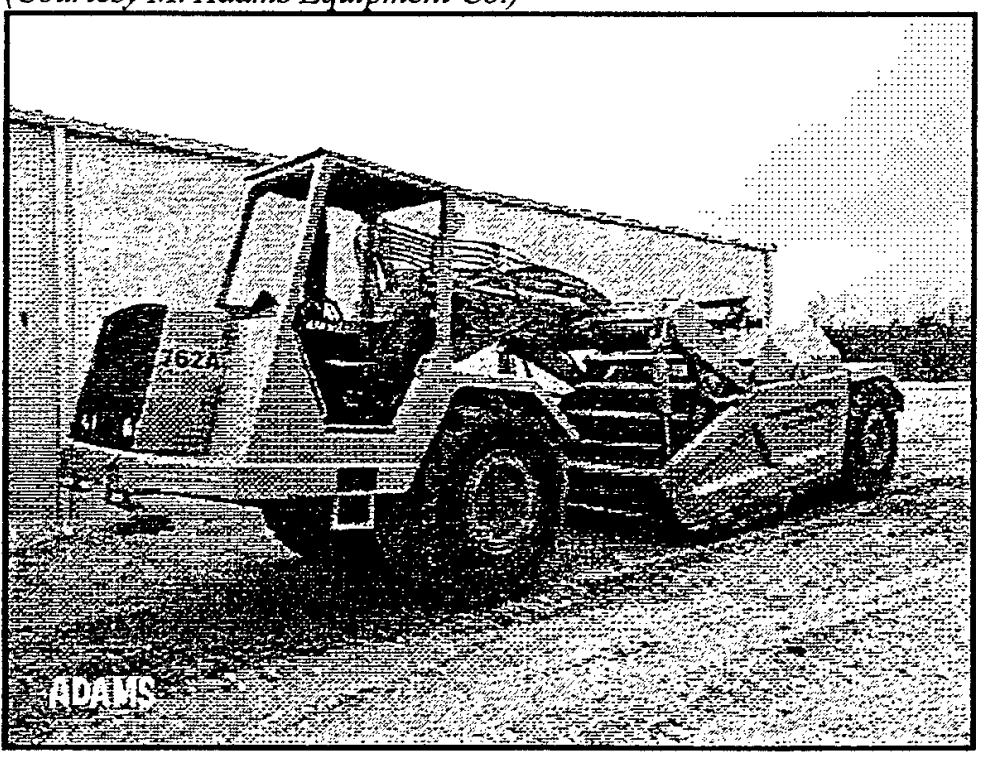

Scraper production is estimated based on the scraper's cycle time and hauling capacity; much like other equipment.

A scraper's cycle time is based on fixed cycle time and variable cycle time. Fixed cycle time includes the time required to spot, load, and maneuver and dump. Table 9-2 provides typical values of scraper fixed cycle times. 
Table 9-2

Scraper Fixed Cycle Time (min)

\begin{tabular}{|c|c|c|c|c|c|}
\hline & & \multicolumn{3}{|c|}{ Spot Time } & \\
\hline & & Single Pusher & & Tandem Pusher & \\
\hline Favorable & & 0.2 & & 0.1 & \\
\hline Average & & 0.3 & & 0.2 & \\
\hline \multirow[t]{3}{*}{ Unfavorable } & & 0.5 & & 0.5 & \\
\hline & \multicolumn{5}{|c|}{ Load Time } \\
\hline & Single Pusher & $\begin{array}{l}\text { Tandem } \\
\text { Pusher }\end{array}$ & $\begin{array}{c}\text { Elevating } \\
\text { Scraper }\end{array}$ & Auger & Push-Pull* \\
\hline Favorable & 0.5 & 0.4 & 0.8 & 0.7 & 0.7 \\
\hline Average & 0.6 & 0.5 & 1.0 & 0.9 & 1.0 \\
\hline \multirow[t]{3}{*}{ Unfavorable } & 1.0 & 0.9 & 1.5 & 1.3 & 1.4 \\
\hline & \multicolumn{4}{|c|}{$\begin{array}{c}\text { Maneuver \& } \\
\text { Dump }\end{array}$} & \\
\hline & & Single Engine & & Twin Engine & \\
\hline Favorable & & 0.3 & & 0.3 & \\
\hline Average & & 0.7 & & 0.6 & \\
\hline Unfavorable & & 1.0 & & 0.9 & \\
\hline
\end{tabular}

*Per pair of scrapers

Data for this table was extracted from Reference 3, p. 109

The second element of a scraper's cycle time is the variable cycle time. Variable cycle time includes the sum of the time required to haul the material, dump the material, and return to the point of excavation. One method of estimating variable cycle for scrapers is to use travel time curves (Figures 9-3 \& 9-4). The haul route will need to be broken into sections with similar characteristics of grade, load, etc.. 
Figure 9-3

Scraper Distance versus Time (loaded)

(Courtesy of Caterpillar, Inc.)

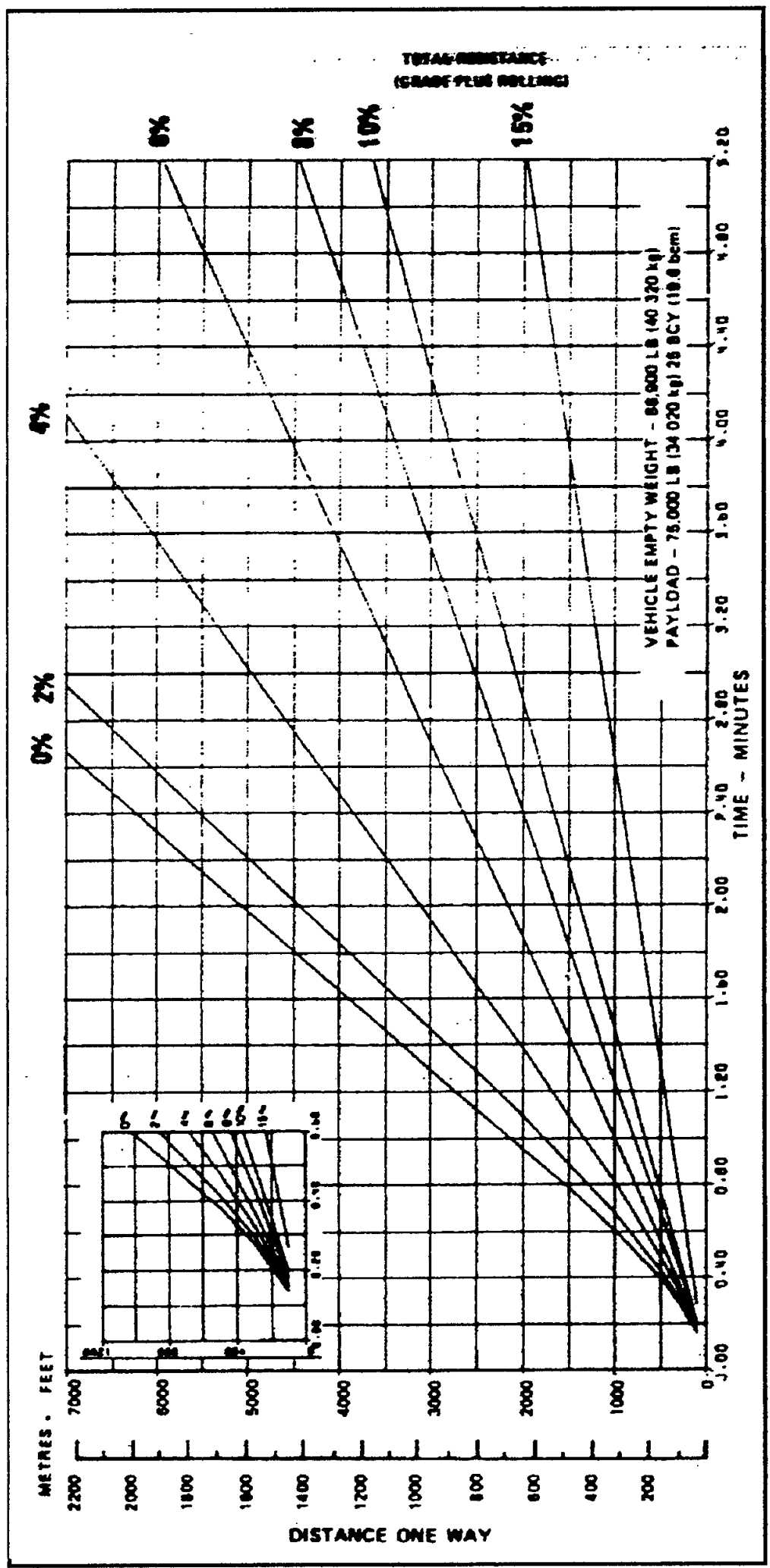


Figure 9-4

Scraper Distance versus Time (empty)

(Courtesy of Caterpillar, Inc.)

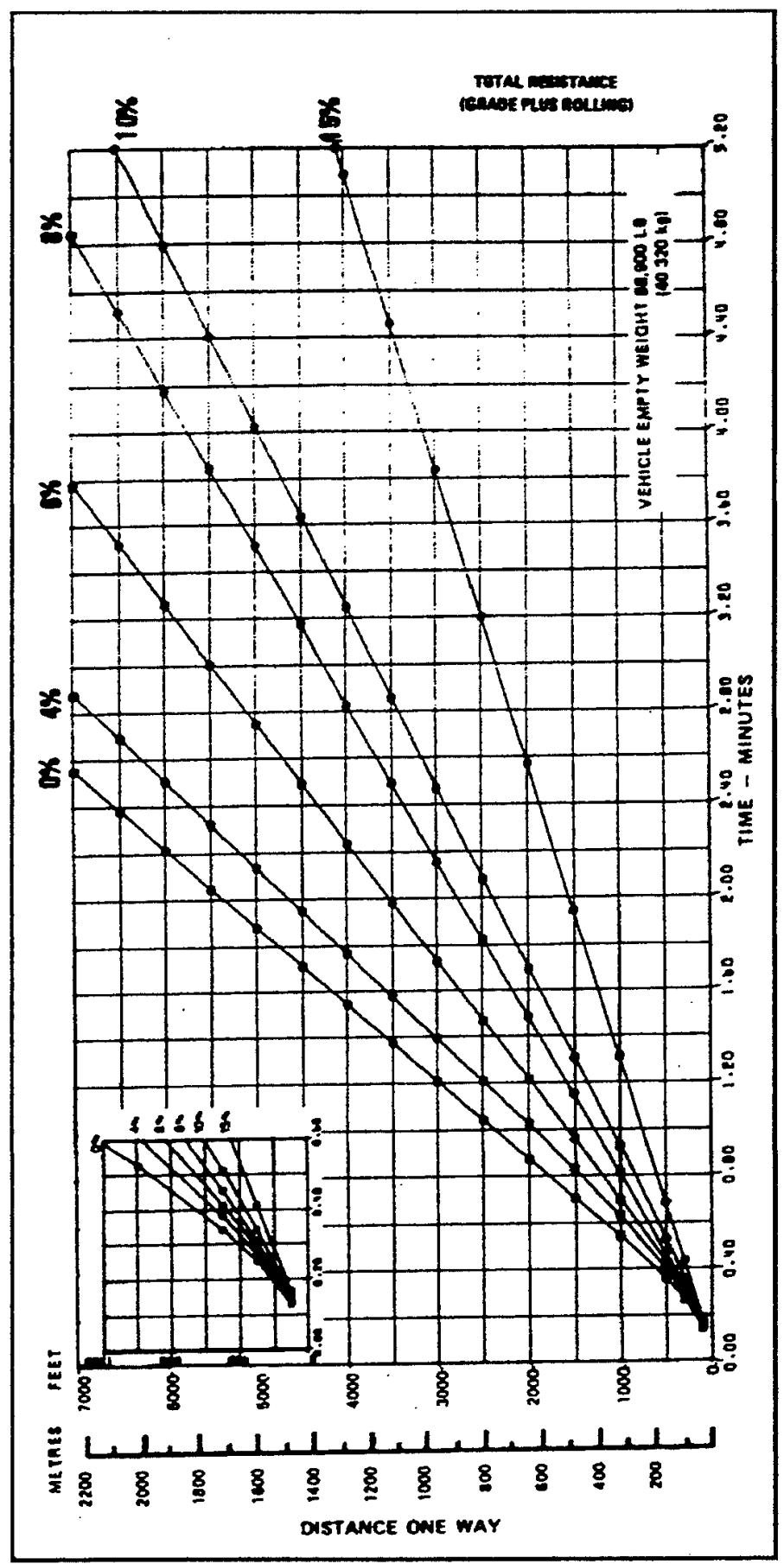


In determining a scrapers per cycle capacity, one must consider both the scrapers rated payload capacity and volumetric capacity. The governing value will be the lesser of the two capacities. For example, if a scraper is rated for a $50,000 \mathrm{lb}$ payload and 30 LCY's volume, and the material being excavate has a unit weight of $2,000 \mathrm{lb} / \mathrm{LCY}$, then payload would govern, because $30 \mathrm{LCY}$ 's of a $2,000 \mathrm{lb} / \mathrm{LCY}$ material would weigh $60,000 \mathrm{lb}$, which exceeds the rated payload capacity. Therefore, in this example the scraper could only handle a volume of $50,000 \mathrm{lb}$ divided by $2,000 \mathrm{lb} / \mathrm{LCY}$ or $25 \mathrm{LCY}$ of material not the rated $30 \mathrm{LCY}$.

\section{Example 9-1}

A single engine tandem pusher scraper, which has travel time/distance curves as shown in figures 9-3 \& 9-4 is being used to excavate for a large parking lot. The scraper has a heaped volume capacity of $30 \mathrm{LCY}$, and a maximum payload capacity of 65,000 lb. The material being removed is sand with a unit weight of 2,800 lb/LCY and 3,200 $\mathrm{lb} / \mathrm{BCY}$. The job conditions are average and job efficiency is equivalent to $50 \mathrm{~min} / \mathrm{hr}$. The scraper is working in a dirt roadway environment with approximately 1.5 inch of tire penetration. The haul route can be broken up as follows:

1. Level loading area

2. Haul down a $4 \%$ grade for 1,500 feet

3. Level dump area

4. Return up a $4 \%$ grade for 1,500 feet

5. Level turnaround of 600 feet

Based on this information, what will is the estimated scraper production?

\section{Solution}

Step 1-Calculate weight of heaped capacity

Weight of Heaped Capacity $=$ Loose Unit Weight $x$ Capacity $=2,8001 b / L C Y \times 30 L C Y$ Weight of Heaped Capacity $=84,000 \mathrm{lb}$

Note: Weight of heaped capacity $(84,000 \mathrm{lb})$ exceeds rated payload capacity of $65,000 \mathrm{Ib}$, therefore scraper will work at less than heaped capacity.

Step 2 - Calculate Moximum Capacity (BCY)

Maximum Capacity $(B C Y)=$ Payload Capacity $\div$ Bank Unit Weight

Maximum Capacity $(B C Y)=65,000 \mathrm{lb} \div 3,200 \mathrm{lb} / \mathrm{BCY}$

Maximum Capacity $=20.31 \mathrm{BCY}$

Step 3 - Calculate Effective Grades (EG)

Where:

$$
E G=\text { Grade }(\%)+[\text { Rolling Resistance Factor (lb/ton) } \div 20]
$$

Haul:

$$
E G=-4 \%+[100 \div 20]=1 \%
$$

Return:

$$
E G=4 \%+[100 \div 20]=9 \%
$$


Turnaround:

$$
E G=0 \%+[100 \div 20]=5 \%
$$

Step 4 - Calculate variable cycle time from Figures 9-3 \& 9-4

$$
\begin{array}{ll}
\text { Houl } & =0.84 \mathrm{~min} \\
\text { Return } & =1.20 \mathrm{~min} \\
\text { Turnaround } & =0.41 \mathrm{~min}
\end{array}
$$

Step 5 - Calculate fixed cycle time from Table 9-2

$$
\begin{array}{ll}
\text { Spot } & =0.2 \mathrm{~min} \\
\text { Load } & =0.5 \mathrm{~min} \\
\text { Maneuver/Dump } & =0.7 \mathrm{~min}
\end{array}
$$

Step 6 - Calculate Total Cycle Time

Total Cycle $=$ fixed cycle + variable $=0.84+1.20+0.41+0.2+0.5+0.7$

$$
\text { Total Cycle }=3.85 \mathrm{~min}
$$

Step 7 - Calculate estimated production

Estimated Production $=[$ Moximum Capacity $(B C Y) \times$ Efficiency $(\mathrm{min} / \mathrm{hr})] \div$ Total Cycle Estimated Production $=[20.31 \mathrm{BCY} \times 50 \mathrm{~min} / \mathrm{hr}] \div 3.85 \mathrm{~min}$ Estimated Production $=\underline{263.8 \mathrm{BCY} / \mathrm{hr}}$

\subsection{Push Loading}

Sometimes the available power of scraper is not sufficient to allow the scraper to operate under its own power. In such a case the equipment manager will want to employ a method know as push loading. Push loading is when a tractor is used to push a scraper during the scraping operation. Figure 9-5 is an example of a scraper being push loaded.

Figure 9-5

Scraper Being Push Loaded

(Extracted from Reference 6, p. 117)

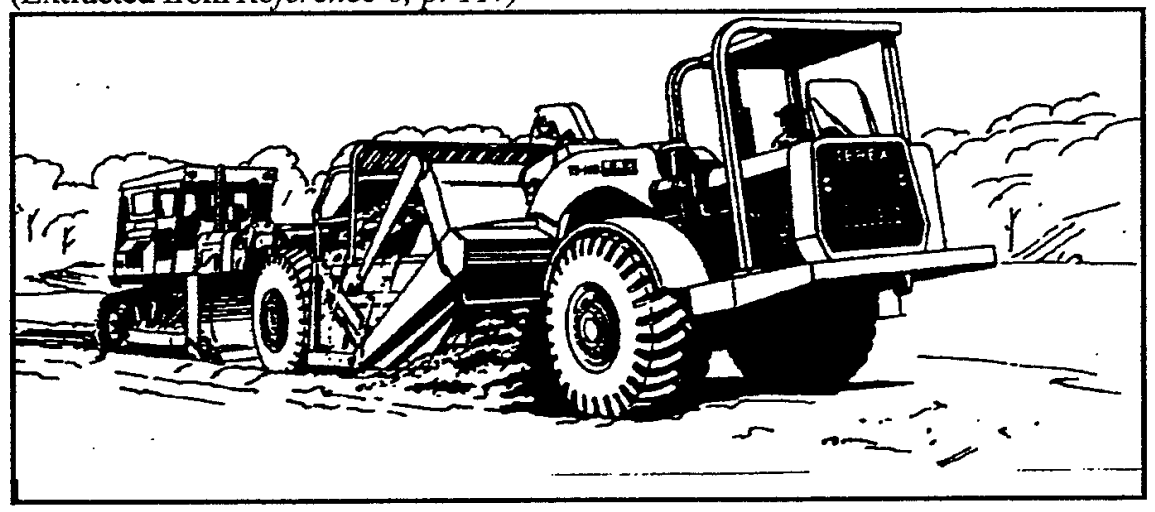


There are three basic methods of push loading. The three methods are Back Track Loading, Chain Loading, and Shuttle Loading. Figure 9-6 illustrates the three methods of push loading. Typically push loading will be accomplished by using either one pusher per scraper or two pushers per scraper. 
Figure 9-6

Methods of Push Loading

(Extracted from Reference 3, p. 113)

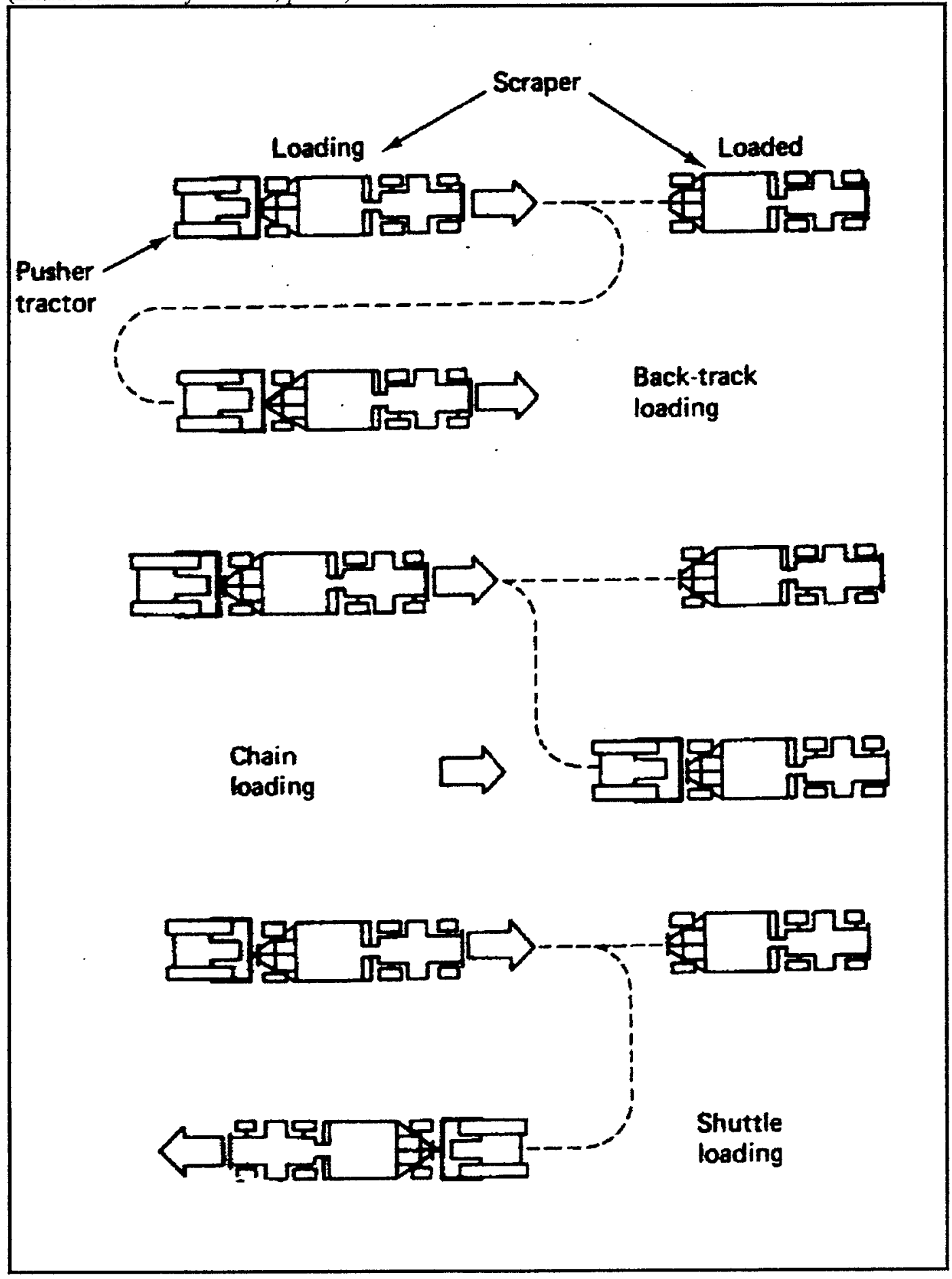


Because a tractor is involved in a push loading operation, it is important to be able to determine the number of scrapers that a pusher can support, and the number of pushers required to support a fleet of scrapers: These numbers can be obtained with the following equations:

No. scrapers served by one pusher $=$ Scraper Cycle Time $\div$ Pusher Cycle Time

\section{Number of Pushers Required $=$ Number of Scrapers $\div$ No. scrapers served by one pusher}

Table 9-3 provides a list of typical pusher cycle times.

Table 9-3

Typical Pusher Cycle Times (min)

\begin{tabular}{lcc}
\hline Loading Method & Single Pusher & Tandem Pusher \\
\hline Back Track & 1.5 & 1.4 \\
Chain or Shuttle & 1.0 & 0.9 \\
\hline Date &
\end{tabular}

Data for this table was extracted from Reference 3, p. 116

To determine the expected production of a scraper fleet the following equation applies:

Fleet Production $=[$ No. of Pushers $\div$ No. Pushers Required $] \times$ No. Scrapers $x$ Single Scraper Production

\section{Example 9-2}

A contractor is employing a fleet of 6 scrapers with single pushers for back track push loading. The estimated cycle time for each scraper is 5 minutes. The scropers hove a capacity of $200 \mathrm{BCY}$ per hour, and the contractor has 3 dozers available for pushig.

(a) What is the mumber of pushers required to serve the fleet? (b) What is the estimated production of this fleet?

\section{Solution}

(a)

No. scrapers served by one pusher $=5 \mathrm{~min} \div 1.5=3.33$ scrapers/pusher

No. pushers required $=6 \div 3.33=\underline{1.8 \text { use } 2 \text { pushers }}$

(b)

Fleet Production $=[3 \div 3.33] \times 6 \times 200 \mathrm{BCY} / \mathrm{hr}=\underline{1081.1 \mathrm{BCY} / \mathrm{hr}}$ 


\subsection{Trucks}

It is obvious that hauling is a major part of any earthmoving process, and the most prevalent piece of equipment used for hauling materials in the construction industry is the truck. Many trucks are licensed for highway use, which is of particular usefulness when a borrow pit or dump site is located some distance from the construction site. Knowing that trucks are one of the most popular haulers, it is important to be familiar with estimating truck production.

Truck production is based on cycle time. A truck's cycle time has two components, fixed cycle time and variable cycle time. Fixed cycle time is the time required for spot, maneuver, and dump. Table 9-4 list typical fixed cycle times for trucks. The second component of truck cycle time is the variable component. Variable cycle time consists of the load time and haul time. Load time is given by the following equation:

\section{Load Time $=$ Haul Unit Capacity $\div$ Loader Production}

The haul time can simply be calculated by dividing the distance to the dump site by the average speed of the truck.

Table 9-4

Typical Truck Fixed Cycle Times (min)

\begin{tabular}{lcc}
\hline & Bottom Dump & Rear Dump \\
\cline { 2 - 3 } Favorable & 1.1 & 0.5 \\
Average & 1.6 & 1.1 \\
Unfavorable & 2.0 & 2.5 \\
\hline
\end{tabular}

Data for this table was extracted from Reference 3, p. 121

Because it is inefficient to have either loaders or haulers sitting idle, it is important to accurately calculate the number of haul units required to support a loading operation. The number of haulers required to support a loading operation is given by:

\section{Number of haulers required $=$ Haul Unit Cycle Time $\div$ Load Time}

The aforementioned equation provides the theoretical number of haulers required for a loading operation, however, the actual number of haulers available may differ from 
the theoretical number required. When the actual number of haulers differs from the theoretical number required, production can be estimated with the following equation:

\section{Expected Production $=($ Haul Units Available $\div$ Number Haulers Required $) \times 1$ loader production}

\section{Example 9-3}

Based on the following loader truck operation, (a) calculate the number of trucks required theoretically to support the operation; (b) calculate the expected production if 8 trucks are available.

Solution

$$
\begin{array}{ll}
\text { Loader Production } & =350 \mathrm{BCY} / \mathrm{hr} \\
\text { Job Efficiency } & =50 \mathrm{~min} / \mathrm{hr} \\
\text { Truck Capacity } & =20 \mathrm{BCY} \\
\text { Truck Cycle Time } & =0.5 \mathrm{hr} \text { (not including loading) }
\end{array}
$$

(a)

Step 1 - Calculate Load Time

Load Time $=$ Haul Unit Capacity $\div$ Loader Production $=20 \mathrm{BCY} \div 350 \mathrm{BCY} / \mathrm{hr}$

$$
\text { Load Time }=0.057 \mathrm{hr}
$$

Step 2 - Calculate Truck Cycle Time

$$
\text { Truck Cycle }=0.5 \mathrm{hr}+0.057 \mathrm{hr}=0.557 \mathrm{hr}
$$

Step 3 - Calculate Number Trucks Required

Number Trucks Required $=$ Haul Unit Cycle Time $\div$ Load Time

Number Trucks Required $=0.557 \mathrm{hr} \div 0.057$

(b)

Number Trucks Required $=\underline{9.8 \text { (in theory) }}$

Step I - Calculate Expected Production of 8 Trucks

Expected Production $=($ Haul Units Available $\div$ Number Haulers Required $) x$ loader production

Expected Production $=(8 \div 9.8) \times 50 \mathrm{~min} / 60 \mathrm{~min} \times 350 \mathrm{BCY} / \mathrm{hr}$

Expected Production $=\underline{238 \mathrm{BCY} / \mathrm{hr}}$ 


\section{Equipment Selection}

It is often necessary for an equipment manager to evaluate two equipment alternatives to determine which is the most advantageous. The alternatives being evaluated will likely have different costs per quantity, costs per time, and fixed costs. There are several methods for making this determination, but only one method will be presented here, and that method is the Line of Balance Method.

\subsection{Line of Balance}

The Line of Balance Method is a mathematical model for analyzing two equipment alternatives for the purpose of selecting the most advantageous.

To employ the Line of Balance Method a cost equation for each option must be developed. The equation will take into account fixed costs, time dependant costs, and quantity dependant costs.

\section{Fixed Costs include, but are not limited to:}

- Move In

- Move Out

- Mobilization

- Demobilization

- Purchase Price

Time dependant costs include, but are not limited to:

- Rental Costs

- Interest

Quantity dependant costs include, but are not limited to:

- Wages

- Operating Costs

The total costs of each option will include the sum of fixed costs, time dependant costs, and quantity dependant costs. The following equation represents the total costs of a given option:

$$
\mathbf{C t}=\mathbf{C f}+\mathbf{C t d}+\mathbf{C q t y}
$$


Where $\mathrm{Ct}=$ Total Cost

Cf $\quad=$ Fixed Costs

Ctd = Time Dependant Costs

Cqty = Quantity Dependant Costs

\section{Example 10-1}

Find the cost equation for an equipment option with the following cost data:

Equation

$$
\begin{array}{ll}
\text { Move in/Move out } & =\$ 2,000 \\
\text { Monthly Rental } & =\$ 1,500 / \text { month } \\
\text { Productivity } & =6 \mathrm{CY} / \mathrm{hr} \\
\text { Labor Costs } & =\$ 25 / \mathrm{hr} \\
\text { Operating Costs } & =\$ 5 / \mathrm{hr}
\end{array}
$$

Where $\quad T=$ Time (months)

$$
\begin{gathered}
C t=2,000+1,500 T+[(\$ 25+\$ 5) \div 6 C Y / h r] Q \\
C t=2,000+1,500 T+5 Q
\end{gathered}
$$$$
Q=\text { Quantity (cubic yards) }
$$

Once the equation for each option is obtained, the equations are set equal to one

\begin{tabular}{|c|c|c|}
\hline & Small Mixer & Large Mixer \\
\hline Mobilization/Demobilization & $\$ 2,000$ & $\$ 4,000$ \\
\hline Monthly Rental Costs & $\$ 1,500 /$ month & $\$ 2,500 /$ month \\
\hline Productivity & $6 \mathrm{CY} / \mathrm{hr}$ & $10 \mathrm{CY} / \mathrm{hr}$ \\
\hline Number of Laborers & 5 & 3 \\
\hline Wages & $\$ 5 / \mathrm{hr}$ & $\$ 6 / \mathrm{hr}$ \\
\hline Operating Cost & $\$ 5 / \mathrm{hr}$ & $\$ 2 / \mathrm{hr}$ \\
\hline
\end{tabular}
another, such that the resulting combined equation is that of a straight line. This equation is then plotted. From this plot a determination of which option is best for a given quantity and time can be made. The following example illustrates the entire Line of Balance Method.

\section{Example 10-2}

Data

This equipment will be used to place 1000 cubic yards of concrete, and it must be completed within 3 months. Which mixer is more advantageous?

\section{Solution}

Step 1 -Calculate the cost equation for the small mixer

Csmall mixer $=2,000+1,500 T+[((\$ 5 \times 5)+\$ 5) \div 6 \mathrm{CY} / \mathrm{hr}] Q$

Csmall mixer $=2,000+1,500 T+5 Q$

Step 2 - Calculate the cost equation for the large mixer 


$$
\begin{gathered}
\text { Clarge mixer }=4,000+2,500 T+[((\$ 6 \times 3)+\$ 2)] \div 10 \mathrm{CY} / \mathrm{hr}] Q \\
\text { Clarge mixer }=4,000+2,500 T+2 Q
\end{gathered}
$$

Step 3 - Combine Cost Equations

$$
\begin{gathered}
\text { Csmall mixer }=\text { Clarge mixer } \\
2000+1,500 T+5 Q=4,000+2,500 T+2 Q \\
Q=(2,000+1000 T) \div 3
\end{gathered}
$$

Step 4 - Plot combined equation

\section{Combined Equation Plot}

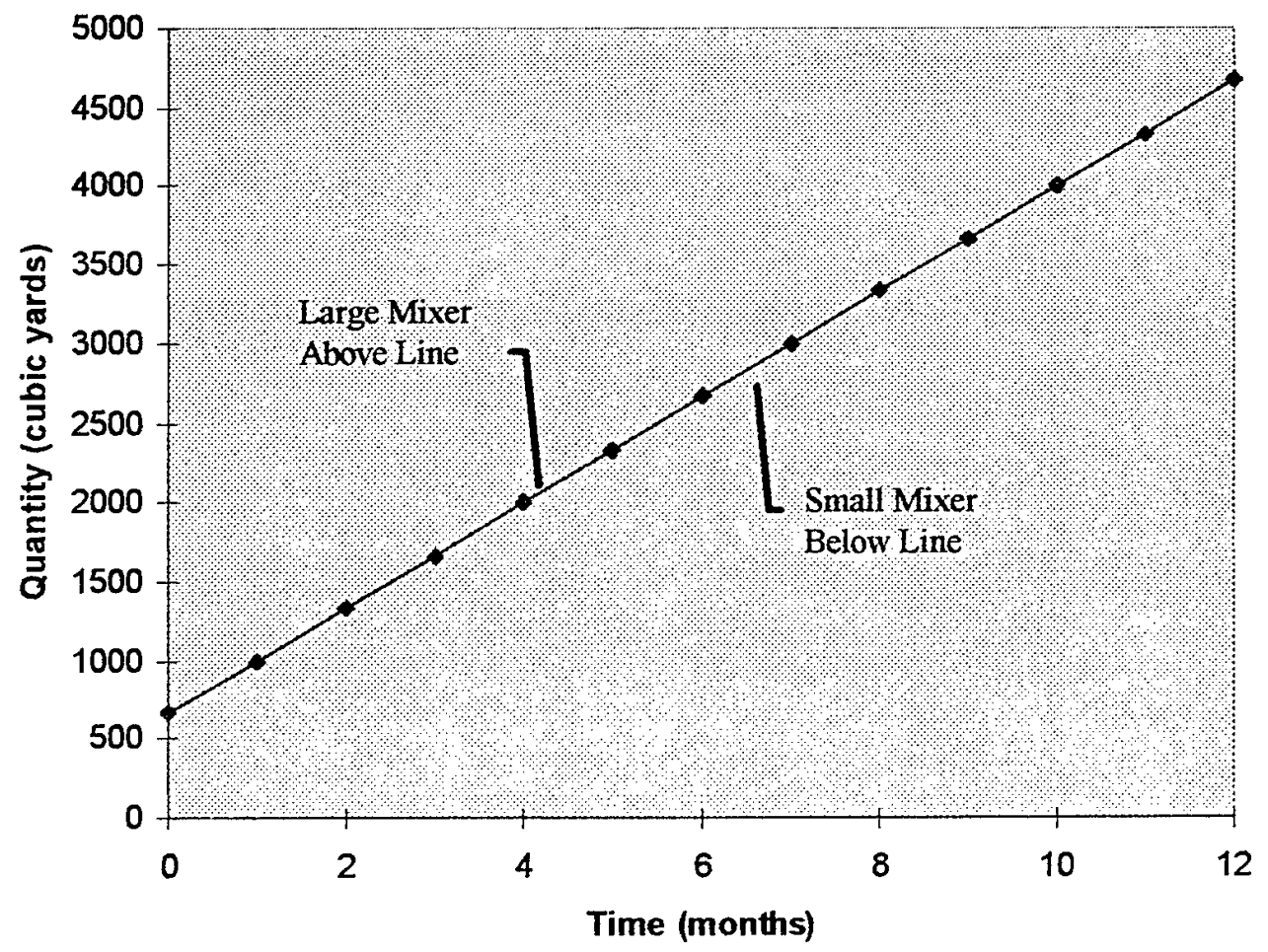

Step 5 - Use 3 months and 1,000 cubic yards and solve for each mixer equation. Small Mixer

$$
\begin{gathered}
\text { Csmall mixer }=2,000+1,500(3)+5(1000) \\
\text { Csmall mixer }=\$ 11,500
\end{gathered}
$$

Large Mixer

$$
\begin{gathered}
\text { Clarge mixer }=4,000+2,500(3)+2(1000) \\
\text { Clarge } \text { mixer }=\$ 13,500
\end{gathered}
$$

From this it can be determined that at 3 months and 1000 cubic yards the small mixer is more advantageous, and the intersection of 3 months and 1000 cubic yards falls below the plotted line. Therefore, the area below the line represents the area more advantageous to the small mixer and visa versa.

What would happen if there was a mistake in estimating the quantity, and the job required 2,000 cubic yards instead of 1,000 cubic yards? 
In this case the intersection of 3 months and 2,000 cubic yards falls above the plotted line. Therefore, the large mixer would be selected.

In the preceding example the Line of Balance Method was used to evaluate two pieces of equipment. It should be noted that this method is not limited to only two pieces of equipment. This method could be used to analyze multiple options. 


\section{References}

1. Day, David A., Construction Equipment Guide, Second Edition, John Wiley \& Sons, Inc., New York, 1991

2. Drevdahl, Elmer R., Fundamentals of Excavation Equipment, Roadrunner Technical Publications Desert Laboratories, Inc., Arizona, 1963

3. Nunnally, S. W., Construction Methods and Management, Prentice-Hall, Inc., New Jersey, 1998

4. Nunnally, S. W., Managing Construction Equipment, Prentice-Hall, Inc., New Jersey, 1977

5. Peurifoy, R. L. and W. B. Ledbetter, Construction Planning Equipment, and Methods, Fourth Edition, McGraw-Hill, Inc., 1985

6. Schaufelberger, John E., Construction Equipment Management, PrenticeHall, Inc., New Jersey, 1999

7. White, John A., Marvin H. Agee, and Kenneth E. Case, Principles of Engineering Economic Analysis, Third Edition, John Wiley \& Sons, Inc., New York, 1989

8. U. S. Army Corps of Engineers, Construction Equipment Ownership and Operating Expense Schedule, Volume II, August 1995

9. Rental Rate Blue Book, Volume 1, Dataquest Incorporated, 1992 
Appendix A

Compound Interest Tables 
Compound intereste Table for: $i=1 \%$

\begin{tabular}{|c|c|c|c|c|c|c|}
\hline & \multicolumn{2}{|c|}{ Single Payment } & \multicolumn{4}{|c|}{ Uniform Series } \\
\hline & $\begin{array}{l}\text { Compound Amount } \\
\text { Factor }\end{array}$ & $\begin{array}{c}\text { Present Worth } \\
\text { Factor }\end{array}$ & $\begin{array}{l}\text { Compound Amount } \\
\text { Factor }\end{array}$ & Sinking Fund Factor & \begin{tabular}{|c|}
$\begin{array}{c}\text { Present Worth } \\
\text { Factor }\end{array}$ \\
\end{tabular} & $\begin{array}{c}\begin{array}{c}\text { Capital Recovery } \\
\text { Factor }\end{array} \\
\end{array}$ \\
\hline $\mathbf{n}$ & $\begin{array}{c}\text { To find } F \text { when given } \\
\text { a } P \\
\text { (F/P, i, n) }\end{array}$ & $\begin{array}{c}\text { To find } P \text { when given } \\
\text { an } F \\
(P / F, i, n)\end{array}$ & $\begin{array}{c}\text { To find } F \text { when given } \\
\text { an } A \\
(F / A, i, n)\end{array}$ & $\begin{array}{c}\text { To find } A \text { when given } \\
\text { an } F \\
\text { (AF, i, n) }\end{array}$ & $\begin{array}{c}\text { To find } P \text { when given } \\
\text { an } A \\
\text { (P/A, i, n) }\end{array}$ & $\begin{array}{c}\text { To find } A \text { when given } \\
\text { a } \\
\text { (AP, } \mathrm{i}, \mathrm{n} \text { ) }\end{array}$ \\
\hline 1 & 1.0100 & 0.9901 & 1.0000 & 1.0000 & 0.9901 & 1.0100 \\
\hline 2 & 1.0201 & 0.9803 & 2.0100 & 0.4975 & 1.9704 & 0.5075 \\
\hline 3 & 1.0303 & 0.9706 & 3.0301 & 0.3300 & 2.9410 & 0.3400 \\
\hline 4 & 1.0406 & 0.9610 & 4.0604 & 0.2463 & 3.9020 & 0.2563 \\
\hline 5 & 1.0510 & 0.9515 & 5.1010 & 0.1960 & 4.8534 & 0.2060 \\
\hline 6 & 1.0615 & 0.9420 & 6.1520 & 0.1625 & 5.7955 & 0.1725 \\
\hline 7 & 1.0721 & 0.9327 & 7.2135 & 0.1386 & 6.7282 & 0.1486 \\
\hline 8 & 1.0829 & 0.9235 & 8.2857 & 0.1207 & 7.6517 & 0.1307 \\
\hline 9 & 1.0937 & 0.9143 & 9.3685 & 0.1067 & 8.5660 & 0.1167 \\
\hline 10 & 1.1046 & 0.9053 & 10.4622 & 0.0956 & 9.4713 & 0.1056 \\
\hline 11 & 1.1157 & 0.8963 & 11.5668 & 0.0865 & 10.3676 & 0.0965 \\
\hline 12 & 1.1268 & 0.8874 & 12.6825 & 0.0788 & 11.2551 & 0.0888 \\
\hline 13 & 1.1381 & 0.8787 & 13.8093 & 0.0724 & 12.1337 & 0.0824 \\
\hline 14 & 1.1495 & 0.8700 & 14.9474 & 0.0669 & 13.0037 & 0.0769 \\
\hline 15 & 1.1610 & 0.8613 & 16.0969 & 0.0621 & 13.8651 & 0.0721 \\
\hline 16 & 1.1726 & 0.8528 & 17.2579 & 0.0579 & 14.7179 & 0.0679 \\
\hline 17 & 1.1843 & 0.8444 & 18.4304 & 0.0543 & 15.5623 & 0.0643 \\
\hline 18 & 1.1961 & 0.8360 & 19.6147 & 0.0510 & 16.3983 & 0.0610 \\
\hline 19 & 1.2081 & 0.8277 & 20.8109 & 0.0481 & 17.2260 & 0.0581 \\
\hline 20 & 1.2202 & 0.8195 & 22.0190 & 0.0454 & 18.0456 & 0.0554 \\
\hline 21 & 1.2324 & 0.8114 & 23.2392 & 0.0430 & 18.8570 & 0.0530 \\
\hline 22 & 1.2447 & 0.8034 & 24.4716 & 0.0409 & 19.6604 & 0.0509 \\
\hline 23 & 1.2572 & 0.7954 & 25.7163 & 0.0389 & 20.4558 & 0.0489 \\
\hline 24 & 1.2697 & 0.7876 & 26.9735 & 0.0371 & 21.2434 & 0.0471 \\
\hline 25 & 1.2824 & 0.7798 & 28.2432 & 0.0354 & 22.0232 & 0.0454 \\
\hline 26 & 1.2953 & 0.7720 & 29.5256 & 0.0339 & 22.7952 & 0.0439 \\
\hline 27 & 1.3082 & 0.7644 & 30.8209 & 0.0324 & 23.5596 & 0.0424 \\
\hline 28 & 1.3213 & 0.7568 & 32.1291 & 0.0311 & 24.3164 & 0.0411 \\
\hline 29 & 1.3345 & 0.7493 & 33.4504 & 0.0299 & 25.0658 & 0.0399 \\
\hline 30 & 1.3478 & 0.7419 & 34.7849 & 0.0287 & 25.8077 & 0.0387 \\
\hline 31 & 1.3613 & 0.7346 & 36.1327 & 0.0277 & 26.5423 & 0.0377 \\
\hline 32 & 1.3749 & 0.7273 & 37.4941 & 0.0267 & 27.2696 & 0.0367 \\
\hline 33 & 1.3887 & 0.7201 & 38.8690 & 0.0257 & 27.9897 & 0.0357 \\
\hline 34 & 1.4026 & 0.7130 & 40.2577 & 0.0248 & 28.7027 & 0.0348 \\
\hline 35 & 1.4166 & 0.7059 & 41.6603 & 0.0240 & 29.4086 & 0.0340 \\
\hline 36 & 1.4308 & 0.6989 & 43.0769 & 0.0232 & 30.1075 & 0.0332 \\
\hline 37 & 1.4451 & 0.6920 & 44.5076 & 0.0225 & 30.7995 & 0.0325 \\
\hline 38 & 1.4595 & 0.6852 & 45.9527 & 0.0218 & 31.4847 & 0.0318 \\
\hline 39 & 1.4741 & 0.6784 & 47.4123 & 0.0211 & 32.1630 & 0.0311 \\
\hline 40 & 1.4889 & 0.6717 & 48.8864 & 0.0205 & 32.8347 & 0.0305 \\
\hline 45 & 1.5648 & 0.6391 & 56.4811 & 0.0177 & 36.0945 & 0.0277 \\
\hline 48 & 1.6122 & 0.6203 & 61.2226 & 0.0163 & 37.9740 & 0.0263 \\
\hline 50 & 1.6446 & 0.6080 & 64.4632 & 0.0155 & 39.1961 & 0.0255 \\
\hline 54 & 1.7114 & 0.5843 & 71.1410 & 0.0141 & 41.5687 & 0.0241 \\
\hline 60 & 1.8167 & 0.5504 & 81.6697 & 0.0122 & 44.9550 & 0.0222 \\
\hline
\end{tabular}


Compound Intereste Table for: $i=2 \%$

\begin{tabular}{|c|c|c|c|c|c|c|}
\hline & \multicolumn{2}{|c|}{ Single Payment } & \multicolumn{4}{|c|}{ Uhiform Series } \\
\hline & $\begin{array}{l}\text { Compound Amount } \\
\text { Factor }\end{array}$ & $\begin{array}{l}\text { Present Worth } \\
\text { Factor }\end{array}$ & $\begin{array}{l}\text { Compound Amount } \\
\text { Factor }\end{array}$ & Sinking Fund Factor & $\begin{array}{l}\text { Present Worth } \\
\text { Factor }\end{array}$ & $\begin{array}{c}\text { Capitad Recovery } \\
\text { Factor }\end{array}$ \\
\hline $\mathbf{n}$ & $\begin{array}{c}\text { To find } F \text { when given } \\
\text { a } P \\
(F / P, i, n)\end{array}$ & $\begin{array}{c}\text { To find } P \text { when given } \\
\text { an } F \\
(P / F, i, n)\end{array}$ & $\begin{array}{c}\text { To find } F \text { when given } \\
\text { an } A \\
(F / A, i, n)\end{array}$ & $\begin{array}{c}\text { To find } A \text { when given } \\
\text { an } F \\
\text { (AVF, } \mathbf{i}, n)\end{array}$ & $\begin{array}{c}\text { To find } P \text { when given } \\
\text { an } A \\
(P / A, i, n)\end{array}$ & $\begin{array}{c}\text { To find } A \text { when given } \\
\text { a P } \\
\text { (AVP,i, n) }\end{array}$ \\
\hline 1 & 1.0200 & 0.9804 & 1.0000 & 1.0000 & 0.9804 & 1.0200 \\
\hline 2 & 1.0404 & 0.9612 & 2.0200 & 0.4950 & 1.9416 & 0.5150 \\
\hline 3 & 1.0612 & 0.9423 & 3.0604 & 0.3268 & 2.8839 & 0.3468 \\
\hline 4 & 1.0824 & 0.9238 & 4.1216 & 0.2426 & 3.8077 & 0.2626 \\
\hline 5 & 1.1041 & 0.9057 & 5.2040 & 0.1922 & 4.7135 & 0.2122 \\
\hline 6 & 1.1262 & 0.8880 & 6.3081 & 0.1585 & 5.6014 & 0.1785 \\
\hline 7 & 1.1487 & 0.8706 & 7.4343 & 0.1345 & 6.4720 & 0.1545 \\
\hline 8 & 1.1717 & 0.8535 & 8.5830 & 0.1165 & 7.3255 & 0.1365 \\
\hline 9 & 1.1951 & 0.8368 & 9.7546 & 0.1025 & 8.1622 & 0.1225 \\
\hline 10 & 1.2190 & 0.8203 & 10.9497 & 0.0913 & 8.9826 & 0.1113 \\
\hline 11 & 1.2434 & 0.8043 & 12.1687 & 0.0822 & 9.7868 & 0.1022 \\
\hline 12 & 1.2682 & 0.7885 & 13.4121 & 0.0746 & 10.5753 & 0.0946 \\
\hline 13 & 1.2936 & 0.7730 & 14.6803 & 0.0681 & 11.3484 & 0.0881 \\
\hline 14 & 1.3195 & 0.7579 & 15.9739 & 0.0626 & 12.1062 & 0.0826 \\
\hline 15 & 1.3459 & 0.7430 & 17.2934 & 0.0578 & 12.8493 & 0.0778 \\
\hline 16 & 1.3728 & 0.7284 & 18.6393 & 0.0537 & 13.5777 & 0.0737 \\
\hline 17 & 1.4002 & 0.7142 & 20.0121 & 0.0500 & 14.2919 & 0.0700 \\
\hline 18 & 1.4282 & 0.7002 & 21.4123 & 0.0467 & 14.9920 & 0.0667 \\
\hline 19 & 1.4568 & 0.6864 & 22.8406 & 0.0438 & 15.6785 & 0.0638 \\
\hline 20 & 1.4859 & 0.6730 & 24.2974 & 0.0412 & 16.3514 & 0.0612 \\
\hline 21 & 1.5157 & 0.6598 & 25.7833 & 0.0388 & 17.0112 & 0.0588 \\
\hline 22 & 1.5460 & 0.6468 & 27.2990 & 0.0366 & 17.6580 & 0.0566 \\
\hline 23 & 1.5769 & 0.6342 & 28.8450 & 0.0347 & 18.2922 & 0.0547 \\
\hline 24 & 1.6084 & 0.6217 & 30.4219 & 0.0329 & 18.9139 & 0.0529 \\
\hline 25 & 1.6406 & 0.6095 & 32.0303 & 0.0312 & 19.5235 & 0.0512 \\
\hline 26 & 1.6734 & 0.5976 & 33.6709 & 0.0297 & 20.1210 & 0.0497 \\
\hline 27 & 1.7069 & 0.5859 & 35.3443 & 0.0283 & 20.7069 & 0.0483 \\
\hline 28 & 1.7410 & 0.5744 & 37.0512 & 0.0270 & 21.2813 & 0.0470 \\
\hline 29 & 1.7758 & 0.5631 & 38.7922 & 0.0258 & 21.8444 & 0.0458 \\
\hline 30 & 1.8114 & 0.5521 & 40.5681 & 0.0246 & 22.3965 & 0.0446 \\
\hline 31 & 1.8476 & 0.5412 & 42.3794 & 0.0236 & 22.9377 & 0.0436 \\
\hline 32 & 1.8845 & 0.5306 & 44.2270 & 0.0226 & 23.4683 & 0.0426 \\
\hline 33 & 1.9222 & 0.5202 & 46.1116 & 0.0217 & 23.9886 & 0.0417 \\
\hline 34 & 1.9607 & 0.5100 & 48.0338 & 0.0208 & 24.4986 & 0.0408 \\
\hline 35 & 1.9999 & 0.5000 & 49.9945 & 0.0200 & 24.9986 & 0.0400 \\
\hline 36 & 2.0399 & 0.4902 & 51.9944 & 0.0192 & 25.4888 & 0.0392 \\
\hline 37 & 2.0807 & 0.4806 & 54.0343 & 0.0185 & 25.9695 & 0.0385 \\
\hline 38 & 2.1223 & 0.4712 & 56.1149 & 0.0178 & 26.4406 & 0.0378 \\
\hline 39 & 2.1647 & 0.4619 & 58.2372 & 0.0172 & 26.9026 & 0.0372 \\
\hline 40 & 2.2080 & 0.4529 & 60.4020 & 0.0166 & 27.3555 & 0.0366 \\
\hline 45 & 2.4379 & 0.4102 & 71.8927 & 0.0139 & 29.4902 & 0.0339 \\
\hline 48 & 2.5871 & 0.3865 & 79.3535 & 0.0126 & 30.6731 & 0.0326 \\
\hline 50 & 2.6916 & 0.3715 & 84.5794 & 0.0118 & 31.4236 & 0.0318 \\
\hline 54 & 2.9135 & 0.3432 & 95.6731 & 0.0105 & 32.8383 & 0.0305 \\
\hline 60 & 3.2810 & 0.3048 & 114.0515 & 0.0088 & 34.7609 & 0.0288 \\
\hline
\end{tabular}


Compound Intereste Table for: $\mathrm{i}=3 \%$

\begin{tabular}{|c|c|c|c|c|c|c|}
\hline & \multicolumn{2}{|c|}{ Single Payment } & \multicolumn{4}{|c|}{ Uniform Series } \\
\hline & $\begin{array}{l}\text { Compound Amount } \\
\text { Factor }\end{array}$ & $\begin{array}{c}\text { Present Worth } \\
\text { Factor }\end{array}$ & $\begin{array}{c}\text { Compound Amount } \\
\text { Factor }\end{array}$ & Sinking Fund Factor & \begin{tabular}{|c|}
$\begin{array}{c}\text { Present Worth } \\
\text { Factor }\end{array}$ \\
\end{tabular} & $\begin{array}{c}\begin{array}{c}\text { Capital Recovery } \\
\text { Factor }\end{array} \\
\end{array}$ \\
\hline n & $\begin{array}{c}\text { To find } F \text { when giver } \\
\text { a P } \\
(F / P, i, n)\end{array}$ & $\begin{array}{c}\text { To find } \mathrm{P} \text { when given: } \\
\text { an } \mathrm{F} \\
\text { (P/F, i, n) }\end{array}$ & $\begin{array}{c}\text { To find } F \text { when given } \\
\text { an } A \\
\text { (F/A, } i, n)\end{array}$ & $\begin{array}{c}\text { To find } A \text { when given } \\
\text { an } F \\
(A \cup F, i, n)\end{array}$ & $\begin{array}{c}\text { To find } \mathrm{P} \text { when given } \\
\text { an } \mathrm{A} \\
(\mathrm{P} / \mathrm{A}, \mathrm{i}, \mathrm{n})\end{array}$ & $\begin{array}{c}\text { To find } A \text { when given } \\
\text { a P } \\
\text { (AVP, i, n) }\end{array}$ \\
\hline 1 & 1.0300 & 0.9709 & 1.0000 & 1.0000 & 0.9709 & 1.0300 \\
\hline 2 & 1.0609 & 0.9426 & 2.0300 & 0.4926 & 1.9135 & 0.5226 \\
\hline 3 & 1.0927 & 0.9151 & 3.0909 & 0.3235 & 2.8286 & 0.3535 \\
\hline 4 & 1.1255 & 0.8885 & 4.1836 & 0.2390 & 3.7171 & 0.2690 \\
\hline 5 & 1.1593 & 0.8626 & 5.3091 & 0.1884 & 4.5797 & 0.2184 \\
\hline 6 & 1.1941 & 0.8375 & 6.4684 & 0.1546 & 5.4172 & 0.1846 \\
\hline 7 & 1.2299 & 0.8131 & 7.6625 & 0.1305 & 6.2303 & 0.1605 \\
\hline 8 & 1.2668 & 0.7894 & 8.8923 & 0.1125 & 7.0197 & 0.1425 \\
\hline 9 & 1.3048 & 0.7664 & 10.1591 & 0.0984 & 7.7861 & 0.1284 \\
\hline 10 & 1.3439 & 0.7441 & 11.4639 & 0.0872 & 8.5302 & 0.1172 \\
\hline 11 & 1.3842 & 0.7224 & 12.8078 & 0.0781 & 9.2526 & 0.1081 \\
\hline 12 & 1.4258 & 0.7014 & 14.1920 & 0.0705 & 9.9540 & 0.1005 \\
\hline 13 & 1.4685 & 0.6810 & 15.6178 & 0.0640 & 10.6350 & 0.0940 \\
\hline 14 & 1.5126 & 0.6611 & 17.0863 & 0.0585 & 11.2961 & 0.0885 \\
\hline 15 & 1.5580 & 0.6419 & 18.5989 & 0.0538 & 11.9379 & 0.0838 \\
\hline 16 & 1.6047 & 0.6232 & 20.1569 & 0.0496 & 12.5611 & 0.0796 \\
\hline 17) & 1.6528 & 0.6050 & 21.7616 & 0.0460 & 13.1661 & 0.0760 \\
\hline 18 & 1.7024 & 0.5874 & 23.4144 & 0.0427 & 13.7535 & 0.0727 \\
\hline 19 & 1.7535 & 0.5703 & 25.1169 & 0.0398 & 14.3238 & 0.0698 \\
\hline 20 & 1.8061 & 0.5537 & 26.8704 & 0.0372 & 14.8775 & 0.0672 \\
\hline 21 & 1.8603 & 0.5375 & 28.6765 & 0.0349 & 15.4150 & 0.0649 \\
\hline 22 & 1.9161 & 0.5219 & 30.5368 & 0.0327 & 15.9369 & 0.0627 \\
\hline 23 & 1.9736 & 0.5067 & 32.4529 & 0.0308 & 16.4436 & 0.0608 \\
\hline 24 & 2.0328 & 0.4919 & 34.4265 & 0.0290 & 16.9355 & 0.0590 \\
\hline 25 & 2.0938 & 0.4776 & 36.4593 & 0.0274 & 17.4131 & 0.0574 \\
\hline 26 & 2.1566 & 0.4637 & 38.5530 & 0.0259 & 17.8768 & 0.0559 \\
\hline 27 & 2.2213 & 0.4502 & 40.7096 & 0.0246 & 18.3270 & 0.0546 \\
\hline 28 & 2.2879 & 0.4371 & 42.9309 & 0.0233 & 18.7641 & 0.0533 \\
\hline 29 & 2.3566 & 0.4243 & 45.2189 & 0.0221 & 19.1885 & 0.0521 \\
\hline 30 & 2.4273 & 0.4120 & 47.5754 & 0.0210 & 19.6004 & 0.0510 \\
\hline 31 & 2.5001 & 0.4000 & 50.0027 & 0.0200 & 20.0004 & 0.0500 \\
\hline 32 & 2.5751 & 0.3883 & 52.5028 & 0.0190 & 20.3888 & 0.0490 \\
\hline 33 & 2.6523 & 0.3770 & 55.0778 & 0.0182 & 20.7658 & 0.0482 \\
\hline 34 & 2.7319 & 0.3660 & 57.7302 & 0.0173 & 21.1318 & 0.0473 \\
\hline 35 & 2.8139 & 0.3554 & 60.4621 & 0.0165 & 21.4872 & 0.0465 \\
\hline 36 & 2.8983 & 0.3450 & 63.2759 & 0.0158 & 21.8323 & 0.0458 \\
\hline 37 & 2.9852 & 0.3350 & 66.1742 & 0.0151 & 22.1672 & 0.0451 \\
\hline 38 & 3.0748 & 0.3252 & 69.1594 & 0.0145 & 22.4925 & 0.0445 \\
\hline 39 & 3.1670 & 0.3158 & 72.2342 & 0.0138 & 22.8082 & 0.0438 \\
\hline 40 & 3.2620 & 0.3066 & 75.4013 & 0.0133 & 23.1148 & 0.0433 \\
\hline 45 & 3.7816 & 0.2644 & 92.7199 & 0.0108 & 24.5187 & 0.0408 \\
\hline 48 & 4.1323 & 0.2420 & 104.4084 & 0.0096 & 25.2667 & 0.0396 \\
\hline 50 & 4.3839 & 0.2281 & 112.7969 & 0.0089 & 25.7298 & 0.0389 \\
\hline 54 & 4.9341 & 0.2027 & 131.1375 & 0.0076 & 26.5777 & 0.0376 \\
\hline 60 & 5.8916 & 0.1697 & 163.0534 & 0.0061 & 27.6756 & 0.0361 \\
\hline
\end{tabular}


Compound Intereste Table for: $i=4 \%$

\begin{tabular}{|c|c|c|c|c|c|c|}
\hline & \multicolumn{2}{|c|}{ Single Payment } & \multicolumn{4}{|c|}{ Uniform Series } \\
\hline & $\begin{array}{c}\text { Compound Amount } \\
\text { Factor }\end{array}$ & $\begin{array}{c}\text { Present Worth } \\
\text { Factor }\end{array}$ & $\begin{array}{l}\text { Compound Amount } \\
\text { Factor }\end{array}$ & Sinking Fund Factor & $\begin{array}{c}\begin{array}{c}\text { Present Worth } \\
\text { Factor }\end{array} \\
\end{array}$ & $\begin{array}{c}\text { Capital Recovery } \\
\text { Factor }\end{array}$ \\
\hline $\mathbf{n}$ & $\begin{array}{c}\text { To find } F \text { when given } \\
\text { a P } \\
\text { (F/P, } i, n)\end{array}$ & $\begin{array}{c}\text { To find } P \text { when given } \\
\text { an } F \\
(P / F, i, n)\end{array}$ & $\begin{array}{c}\text { To find } F \text { when given } \\
\text { an } A \\
\text { (F/A, } \mathrm{i}, \mathrm{n})\end{array}$ & $\begin{array}{c}\text { To find } A \text { when given } \\
\text { an } \mathrm{F} \\
\text { (A/F, } \mathrm{i}, \mathrm{n})\end{array}$ & $\begin{array}{c}\text { To find } \mathrm{P} \text { when given } \\
\text { an } \mathrm{A} \\
(\mathrm{P} / \mathrm{A}, \mathrm{i}, \mathrm{n})\end{array}$ & $\begin{array}{c}\text { To find } A \text { when given } \\
\text { aP } \\
\text { (APP, i, n) }\end{array}$ \\
\hline 1 & 1.0400 & 0.9615 & 1.0000 & 1.0000 & 0.9615 & 1.0400 \\
\hline 2 & 1.0816 & 0.9246 & 2.0400 & 0.4902 & 1.8861 & 0.5302 \\
\hline 3 & 1.1249 & 0.8890 & 3.1216 & 0.3203 & 2.7751 & 0.3603 \\
\hline 4 & 1.1699 & 0.8548 & 4.2465 & 0.2355 & 3.6299 & 0.2755 \\
\hline 5 & 1.2167 & 0.8219 & 5.4163 & 0.1846 & 4.4518 & 0.2246 \\
\hline 6 & 1.2653 & 0.7903 & 6.6330 & 0.1508 & 5.2421 & 0.1908 \\
\hline 7 & 1.3159 & 0.7599 & 7.8983 & 0.1266 & 6.0021 & 0.1666 \\
\hline 8 & 1.3686 & 0.7307 & 9.2142 & 0.1085 & 6.7327 & 0.1485 \\
\hline 9 & 1.4233 & 0.7026 & 10.5828 & 0.0945 & 7.4353 & 0.1345 \\
\hline 10 & 1.4802 & 0.6756 & 12.0061 & 0.0833 & 8.1109 & 0.1233 \\
\hline 11 & 1.5395 & 0.6496 & 13.4864 & 0.0741 & 8.7605 & 0.1141 \\
\hline 12 & 1.6010 & 0.6246 & 15.0258 & 0.0666 & 9.3851 & 0.1066 \\
\hline 13 & 1.6651 & 0.6006 & 16.6268 & 0.0601 & 9.9856 & 0.1001 \\
\hline 14 & 1.7317 & 0.5775 & 18.2919 & 0.0547 & 10.5631 & 0.0947 \\
\hline 15 & 1.8009 & 0.5553 & 20.0236 & 0.0490 & 11.1184 & 0.0899 \\
\hline 16 & 1.8730 & 0.5339 & 21.8245 & 0.0458 & 11.6523 & 0.0858 \\
\hline 17 & 1.9479 & 0.5134 & 23.6975 & 0.0422 & 12.1657 & 0.0822 \\
\hline 18 & 2.0258 & 0.4936 & 25.6454 & 0.0390 & 12.6593 & 0.0790 \\
\hline 19 & 2.1068 & 0.4746 & 27.6712 & 0.0361 & 13.1339 & 0.0761 \\
\hline 20 & 2.1911 & 0.4564 & 29.7781 & 0.0336 & 13.5903 & 0.0736 \\
\hline 21 & 2.2788 & 0.4388 & 31.9692 & 0.0313 & 14.0292 & 0.0713 \\
\hline 22 & 2.3699 & 0.4220 & 34.2480 & 0.0292 & 14.4511 & 0.0692 \\
\hline 23 & 2.4647 & 0.4057 & 36.6179 & 0.0273 & 14.8568 & 0.0673 \\
\hline 24 & 2.5633 & 0.3901 & 39.0826 & 0.0256 & 15.2470 & 0.0656 \\
\hline 25 & 2.6658 & 0.3751 & 41.6459 & 0.0240 & 15.6221 & 0.0640 \\
\hline 26 & 2.7725 & 0.3607 & 44.3117 & 0.0226 & 15.9828 & 0.0626 \\
\hline 27 & 2.8834 & 0.3468 & 47.0842 & 0.0212 & 16.3296 & 0.0612 \\
\hline 28 & 2.9987 & 0.3335 & 49.9676 & 0.0200 & 16.6631 & 0.0600 \\
\hline 29 & 3.1187 & 0.3207 & 52.9663 & 0.0189 & 16.9837 & 0.0589 \\
\hline 30 & 3.2434 & 0.3083 & 56.0849 & 0.0178 & 17.2920 & 0.0578 \\
\hline 31 & 3.3731 & 0.2965 & 59.3283 & 0.0169 & 17.5885 & 0.0569 \\
\hline 32 & 3.5081 & 0.2851 & 62.7015 & 0.0159 & 17.8736 & 0.0559 \\
\hline 33 & 3.6484 & 0.2741 & 66.2095 & 0.0151 & 18.1476 & 0.0551 \\
\hline 34 & 3.7943 & 0.2636 & 69.8579 & 0.0143 & 18.4112 & 0.0543 \\
\hline 35 & 3.9461 & 0.2534 & 73.6522 & 0.0136 & 18.6646 & 0.0536 \\
\hline 36 & 4.1039 & 0.2437 & 77.5983 & 0.0129 & 18.9083 & 0.0529 \\
\hline 37 & 4.2681 & 0.2343 & 81.7022 & 0.0122 & 19.1426 & 0.0522 \\
\hline 38 & 4.4388 & 0.2253 & 85.9703 & 0.0116 & 19.3679 & 0.0516 \\
\hline 39 & 4.6164 & 0.2166 & 90.4091 & 0.0111 & 19.5845 & 0.0511 \\
\hline 40 & 4.8010 & 0.2083 & 95.0255 & 0.0105 & 19.7928 & 0.0505 \\
\hline 45 & 5.8412 & 0.1712 & 121.0294 & 0.0083 & 20.7200 & 0.0483 \\
\hline 48 & 6.5705 & 0.1522 & 139.2632 & 0.0072 & 21.1951 & 0.0472 \\
\hline 50 & 7.1067 & 0.1407 & 152.6671 & 0.0066 & 21.4822 & 0.0466 \\
\hline 54 & 8.3138 & 0.1203 & 182.8454 & 0.0055 & 21.9930 & 0.0455 \\
\hline 60 & 10.5196 & 0.0951 & 237.9907 & 0.0042 & 22.6235 & 0.0442 \\
\hline
\end{tabular}


Compound Intereste Table for: $\mathrm{i}=\mathbf{5 \%}$

\begin{tabular}{|c|c|c|c|c|c|c|}
\hline & \multicolumn{2}{|c|}{ Single Payment } & \multicolumn{4}{|c|}{ Uniform Series } \\
\hline & $\begin{array}{l}\text { Compound Amount } \\
\text { Factor }\end{array}$ & $\begin{array}{c}\begin{array}{c}\text { Present Worth } \\
\text { Factor }\end{array} \\
\end{array}$ & $\begin{array}{c}\text { Compound Amount } \\
\text { Factor }\end{array}$ & Sinking Fund Factor & $\begin{array}{c}\text { Present Worth } \\
\text { Factor }\end{array}$ & $\begin{array}{l}\text { Capital Recovery } \\
\text { Factor }\end{array}$ \\
\hline $\mathrm{n}$ & $\begin{array}{c}\text { To find } F \text { when given } \\
\text { a P } \\
\text { (F/P, } i, n \text { ) }\end{array}$ & $\begin{array}{c}\text { To find } P \text { when given } \\
\text { an } F \\
(P / F, i, n)\end{array}$ & $\begin{array}{c}\text { To find } F \text { when giver } \\
\text { an } A \\
\text { (F/A, }, n)\end{array}$ & $\begin{array}{c}\text { To find } A \text { when given } \\
\text { an } F \\
\text { (AVF, } i, n)\end{array}$ & $\begin{array}{c}\text { To find } P \text { when given } \\
\text { an } A \\
(P / A, i, n)\end{array}$ & $\begin{array}{c}\text { To find } A \text { when given } \\
\text { aP } \\
\text { (AVP, } i, n)\end{array}$ \\
\hline 1 & 1.0500 & 0.9524 & 1.0000 & 1.0000 & 0.9524 & 1.0500 \\
\hline 2 & 1.1025 & 0.9070 & 2.0500 & 0.4878 & 1.8594 & 0.5378 \\
\hline 3 & 1.1576 & 0.8638 & 3.1525 & 0.3172 & 2.7232 & 0.3672 \\
\hline 4 & 1.2155 & 0.8227 & 4.3101 & 0.2320 & 3.5460 & 0.2820 \\
\hline 5 & 1.2763 & 0.7835 & 5.5256 & 0.1810 & 4.3295 & 0.2310 \\
\hline 6 & 1.3401 & 0.7462 & 6.8019 & 0.1470 & 5.0757 & 0.1970 \\
\hline 7 & 1.4071 & 0.7107 & 8.1420 & 0.1228 & 5.7864 & 0.1728 \\
\hline 8 & 1.4775 & 0.6768 & 9.5491 & 0.1047 & 6.4632 & 0.1547 \\
\hline 9 & 1.5513 & 0.6446 & 11.0266 & 0.0907 & 7.1078 & 0.1407 \\
\hline 10 & 1.6289 & 0.6139 & 12.5779 & 0.0795 & 7.7217 & 0.1295 \\
\hline 11 & 1.7103 & 0.5847 & 14.2068 & 0.0704 & 8.3064 & 0.1204 \\
\hline 12 & 1.7959 & 0.5568 & 15.9171 & 0.0628 & 8.8633 & 0.1128 \\
\hline 13 & 1.8856 & 0.5303 & 17.7130 & 0.0565 & 9.3936 & 0.1065 \\
\hline 14 & 1.9799 & 0.5051 & 19.5986 & 0.0510 & 9.8986 & 0.1010 \\
\hline 15 & 2.0789 & 0.4810 & 21.5786 & 0.0463 & 10.3797 & 0.0963 \\
\hline 16 & 2.1829 & 0.4581 & 23.6575 & 0.0423 & 10.8378 & 0.0923 \\
\hline 17 & 2.2920 & 0.4363 & 25.8404 & 0.0387 & 11.2741 & 0.0887 \\
\hline 18 & 2.4066 & 0.4155 & 28.1324 & 0.0355 & 11.6896 & 0.0855 \\
\hline 19 & 2.5270 & 0.3957 & 30.5390 & 0.0327 & 12.0853 & 0.0827 \\
\hline 20 & 2.6533 & 0.3769 & 33.0660 & 0.0302 & 12.4622 & 0.0802 \\
\hline 21 & 2.7860 & 0.3589 & 35.7193 & 0.0280 & 12.8212 & 0.0780 \\
\hline 22 & 2.9253 & 0.3418 & 38.5052 & 0.0260 & 13.1630 & 0.0760 \\
\hline 23 & 3.0715 & 0.3256 & 41.4305 & 0.0241 & 13.4886 & 0.0741 \\
\hline 24 & 3.2251 & 0.3101 & 44.5020 & 0.0225 & 13.7986 & 0.0725 \\
\hline 25 & 3.3864 & 0.2953 & 47.7271 & 0.0210 & 14.0939 & 0.0710 \\
\hline 26 & 3.5557 & 0.2812 & 51.1135 & 0.0196 & 14.3752 & 0.0696 \\
\hline 27 & 3.7335 & 0.2678 & 54.6691 & 0.0183 & 14.6430 & 0.0683 \\
\hline 28 & 3.9201 & 0.2551 & 58.4026 & 0.0171 & 14.8981 & 0.0671 \\
\hline 29 & 4.1161 & 0.2429 & 62.3227 & 0.0160 & 15.1411 & 0.0660 \\
\hline 30 & 4.3219 & 0.2314 & 66.4388 & 0.0151 & 15.3725 & 0.0651 \\
\hline 31 & 4.5380 & 0.2204 & 70.7608 & 0.0141 & 15.5928 & 0.0641 \\
\hline 32 & 4.7649 & 0.2099 & 75.2988 & 0.0133 & 15.8027 & 0.0633 \\
\hline 33 & 5.0032 & 0.1999 & 80.0638 & 0.0125 & 16.0025 & 0.0625 \\
\hline 34 & 5.2533 & 0.1904 & 85.0670 & 0.0118 & 16.1929 & 0.0618 \\
\hline 35 & 5.5160 & 0.1813 & 90.3203 & 0.0111 & 16.3742 & 0.0611 \\
\hline 36 & 5.7918 & 0.1727 & 95.8363 & 0.0104 & 16.5469 & 0.0604 \\
\hline 37 & 6.0814 & 0.1644 & 101.6281 & 0.0098 & 16.7113 & 0.0598 \\
\hline 38 & 6.3855 & 0.1566 & 107.7095 & 0.0093 & 16.8679 & 0.0593 \\
\hline 39 & 6.7048 & 0.1491 & 114.0950 & 0.0088 & 17.0170 & 0.0588 \\
\hline 40 & 7.0400 & 0.1420 & 120.7998 & 0.0083 & 17.1591 & 0.0583 \\
\hline 45 & 8.9850 & 0.1113 & 159.7002 & 0.0063 & 17.7741 & 0.0563 \\
\hline 48 & 10.4013 & 0.0961 & 188.0254 & 0.0053 & 18.0772 & 0.0553 \\
\hline 50 & 11.4674 & 0.0872 & 209.3480 & 0.0048 & 18.2559 & 0.0548 \\
\hline 54 & 13.9387 & 0.0717 & 258.7739 & 0.0039 & 18.5651 & 0.0539 \\
\hline 60 & 18.6792 & 0.0535 & 353.5837 & 0.0028 & 18.9293 & 0.0528 \\
\hline
\end{tabular}


Compound Intereste Table for: $i=6 \%$

\begin{tabular}{|c|c|c|c|c|c|c|}
\hline & \multicolumn{2}{|c|}{ Single Payment } & \multicolumn{4}{|c|}{ Uniform Series } \\
\hline & $\begin{array}{c}\text { Compound Amount } \\
\text { Factor }\end{array}$ & $\begin{array}{l}\text { Present Worth } \\
\text { Factor }\end{array}$ & $\begin{array}{l}\text { Compound Amount } \\
\text { Factor }\end{array}$ & Sinking Fund Factor & $\begin{array}{l}\text { Present Worth } \\
\text { Factor }\end{array}$ & $\begin{array}{c}\text { Capital Recovery } \\
\text { Factor }\end{array}$ \\
\hline $\mathbf{n}$ & $\begin{array}{c}\text { To find } F \text { when given } \\
\text { a P } \\
(F / P, i, n)\end{array}$ & $\begin{array}{c}\text { To find } P \text { when given } \\
\text { an } F \\
(P / F, i, n)\end{array}$ & $\begin{array}{c}\text { To find } F \text { when given } \\
\text { an } A \\
\text { (F/A, } \mathrm{i}, \mathrm{n})\end{array}$ & $\begin{array}{c}\text { To find } A \text { when given } \\
\text { an } F \\
\text { (AF, i, n) }\end{array}$ & $\begin{array}{c}\text { To find } P \text { when given } \\
\text { an } A \\
(P / A, i, n)\end{array}$ & $\begin{array}{c}\text { To find } A \text { when given } \\
\text { a P } \\
\text { (AP, i, n) }\end{array}$ \\
\hline 1 & 1.0600 & 0.9434 & 1.0000 & 1.0000 & 0.9434 & 1.0600 \\
\hline 2 & 1.1236 & 0.8900 & 2.0600 & 0.4854 & 1.8334 & 0.5454 \\
\hline 3 & 1.1910 & 0.8396 & 3.1836 & 0.3141 & 2.6730 & 0.3741 \\
\hline 4 & 1.2625 & 0.7921 & 4.3746 & 0.2286 & 3.4651 & 0.2886 \\
\hline 5 & 1.3382 & 0.7473 & 5.6371 & 0.1774 & 4.2124 & 0.2374 \\
\hline 6 & 1.4185 & 0.7050 & 6.9753 & 0.1434 & 4.9173 & 0.2034 \\
\hline 7 & 1.5036 & 0.6651 & 8.3938 & 0.1191 & 5.5824 & 0.1791 \\
\hline 8 & 1.5938 & 0.6274 & 9.8975 & 0.1010 & 6.2098 & 0.1610 \\
\hline 9 & 1.6895 & 0.5919 & 11.4913 & 0.0870 & 6.8017 & 0.1470 \\
\hline 10 & 1.7908 & 0.5584 & 13.1808 & 0.0759 & 7.3601 & 0.1359 \\
\hline 11 & 1.8983 & 0.5268 & 14.9716 & 0.0668 & 7.8869 & 0.1268 \\
\hline 12 & 2.0122 & 0.4970 & 16.8699 & 0.0593 & 8.3838 & 0.1193 \\
\hline 13 & 2.1329 & 0.4688 & 18.8821 & 0.0530 & 8.8527 & 0.1130 \\
\hline 14 & 2.2609 & 0.4423 & 21.0151 & 0.0476 & 9.2950 & 0.1076 \\
\hline 15 & 2.3966 & 0.4173 & 23.2760 & 0.0430 & 9.7122 & 0.1030 \\
\hline 16 & 2.5404 & 0.3936 & 25.6725 & 0.0390 & 10.1059 & 0.0990 \\
\hline 17 & 2.6928 & 0.3714 & 28.2129 & 0.0354 & 10.4773 & 0.0954 \\
\hline 18 & 2.8543 & 0.3503 & 30.9057 & 0.0324 & 10.8276 & 0.0924 \\
\hline 19 & 3.0256 & 0.3305 & 33.7600 & 0.0296 & 11.1581 & 0.0896 \\
\hline 20 & 3.2071 & 0.3118 & 36.7856 & 0.0272 & 11.4699 & 0.0872 \\
\hline 21 & 3.3996 & 0.2942 & 39.9927 & 0.0250 & 11.7641 & 0.0850 \\
\hline 22 & 3.6035 & 0.2775 & 43.3923 & 0.0230 & 12.0416 & 0.0830 \\
\hline 23 & 3.8197 & 0.2618 & 46.9958 & 0.0213 & 12.3034 & 0.0813 \\
\hline 24 & 4.0489 & 0.2470 & 50.8156 & 0.0197 & 12.5504 & 0.0797 \\
\hline 25 & 4.2919 & 0.2330 & 54.8645 & 0.0182 & 12.7834 & 0.0782 \\
\hline 26 & 4.5494 & 0.2198 & 59.1564 & 0.0169 & 13.0032 & 0.0769 \\
\hline 27 & 4.8223 & 0.2074 & 63.7058 & 0.0157 & 13.2105 & 0.0757 \\
\hline 28 & 5.1117 & 0.1956 & 68.5281 & 0.0146 & 13.4062 & 0.0746 \\
\hline 29 & 5.4184 & 0.1846 & 73.6398 & 0.0136 & 13.5907 & 0.0736 \\
\hline 30 & 5.7435 & 0.1741 & 79.0582 & 0.0126 & 13.7648 & 0.0726 \\
\hline 31 & 6.0881 & 0.1643 & 84.8017 & 0.0118 & 13.9291 & 0.0718 \\
\hline 32 & 6.4534 & 0.1550 & 90.8898 & 0.0110 & 14.0840 & 0.0710 \\
\hline 33 & 6.8406 & 0.1462 & 97.3432 & 0.0103 & 14.2302 & 0.0703 \\
\hline 34 & 7.2510 & 0.1379 & 104.1838 & 0.0096 & 14.3681 & 0.0696 \\
\hline 35 & 7.6861 & 0.1301 & 111.4348 & 0.0090 & 14.4982 & 0.0690 \\
\hline 36 & 8.1473 & 0.1227 & 119.1209 & 0.0084 & 14.6210 & 0.0684 \\
\hline 37 & 8.6361 & 0.1158 & 127.2681 & 0.0079 & 14.7368 & 0.0679 \\
\hline 38 & 9.1543 & 0.1092 & 135.9042 & 0.0074 & 14.8460 & 0.0674 \\
\hline 39 & 9.7035 & 0.1031 & 145.0585 & 0.0069 & 14.9491 & 0.0669 \\
\hline 40 & 10.2857 & 0.0972 & 154.7620 & 0.0065 & 15.0463 & 0.0665 \\
\hline 45 & 13.7646 & 0.0727 & 212.7435 & 0.0047 & 15.4558 & 0.0647 \\
\hline 48 & 16.3939 & 0.0610 & 256.5645 & 0.0039 & 15.6500 & 0.0639 \\
\hline 50 & 18.4202 & 0.0543 & 290.3359 & 0.0034 & 15.7619 & 0.0634 \\
\hline 54 & 23.2550 & 0.0430 & 370.9170 & 0.0027 & 15.9500 & 0.0627 \\
\hline 60 & 32.9877 & 0.0303 & 533.1282 & 0.0019 & 16.1614 & 0.0619 \\
\hline
\end{tabular}


Compound Intereste Table for: $\mathrm{i}=7 \%$

\begin{tabular}{|c|c|c|c|c|c|c|}
\hline & \multicolumn{2}{|c|}{ Single Payment } & \multicolumn{4}{|c|}{ Uniform Series } \\
\hline & $\begin{array}{l}\text { Compound Amount } \\
\text { Factor }\end{array}$ & \begin{tabular}{|c|} 
Present Worth \\
Factor
\end{tabular} & $\begin{array}{c}\text { Compound Amount } \\
\text { Factor }\end{array}$ & Sinking Fund Factor & \begin{tabular}{|c|}
$\begin{array}{c}\text { Present Worth } \\
\text { Factor }\end{array}$ \\
\end{tabular} & \begin{tabular}{|c|}
$\begin{array}{c}\text { Capitad Recovery } \\
\text { Factor }\end{array}$ \\
\end{tabular} \\
\hline n) & $\begin{array}{c}\text { To find } F \text { when given } \\
\text { aP } \\
(F / P, j, n)\end{array}$ & $\begin{array}{c}\text { To find } \mathrm{P} \text { when given } \\
\text { an } \mathrm{F} \\
\text { (P/F, } \mathrm{i}, \mathrm{n})\end{array}$ & $\begin{array}{c}\text { To find } F \text { when given } \\
\text { an } A \\
\text { (F/A, } i, n)\end{array}$ & $\begin{array}{c}\text { To find } A \text { when given } \\
\text { an } F \\
\text { (AF, } \mathrm{i}, \mathrm{n})\end{array}$ & $\begin{array}{c}\text { To find } P \text { when given } \\
\text { an } A \\
\text { (P/A, } \mathrm{i}, \mathrm{n}) \\
\end{array}$ & $\begin{array}{c}\text { To find } A \text { when given } \\
\text { a P } \\
\text { (AVP, } i, n)\end{array}$ \\
\hline 1 & 1.0700 & 0.9346 & 1.0000 & 1.0000 & 0.9346 & 1.0700 \\
\hline 2 & 1.1449 & 0.8734 & 2.0700 & 0.4831 & 1.8080 & 0.5531 \\
\hline 3 & 1.2250 & 0.8163 & 3.2149 & 0.3111 & 2.6243 & 0.3811 \\
\hline 4 & 1.3108 & 0.7629 & 4.4399 & 0.2252 & 3.3872 & 0.2952 \\
\hline 5 & 1.4026 & 0.7130 & 5.7507 & 0.1739 & 4.1002 & 0.2439 \\
\hline 6 & 1.5007 & 0.6663 & 7.1533 & 0.1398 & 4.7665 & 0.2098 \\
\hline 7 & 1.6058 & 0.6227 & 8.6540 & 0.1156 & 5.3893 & 0.1856 \\
\hline 8 & 1.7182 & 0.5820 & 10.2598 & 0.0975 & 5.9713 & 0.1675 \\
\hline 9 & 1.8385 & 0.5439 & 11.9780 & 0.0835 & 6.5152 & 0.1535 \\
\hline 10 & 1.9672 & 0.5083 & 13.8164 & 0.0724 & 7.0236 & 0.1424 \\
\hline 11 & 2.1049 & 0.4751 & 15.7836 & 0.0634 & 7.4987 & 0.1334 \\
\hline 12 & 2.2522 & 0.4440 & 17.8885 & 0.0559 & 7.9427 & 0.1259 \\
\hline 13 & 2.4098 & 0.4150 & 20.1406 & 0.0497 & 8.3577 & 0.1197 \\
\hline 14 & 2.5785 & 0.3878 & 22.5505 & 0.0443 & 8.7455 & 0.1143 \\
\hline 15 & 2.7590 & 0.3624 & 25.1290 & 0.0398 & 9.1079 & 0.1098 \\
\hline 16 & 2.9522 & 0.3387 & 27.8881 & 0.0359 & 9.4466 & 0.1059 \\
\hline 17 & 3.1588 & 0.3166 & 30.8402 & 0.0324 & 9.7632 & 0.1024 \\
\hline 18 & 3.3799 & 0.2959 & 33.9990 & 0.0294 & 10.0591 & 0.0994 \\
\hline 19 & 3.6165 & 0.2765 & 37.3790 & 0.0268 & 10.3356 & 0.0968 \\
\hline 20 & 3.8697 & 0.2584 & 40.9955 & 0.0244 & 10.5940 & 0.0944 \\
\hline 21 & 4.1406 & 0.2415 & 44.8652 & 0.0223 & 10.8355 & 0.0923 \\
\hline 22 & 4.4304 & 0.2257 & 49.0057 & 0.0204 & 11.0612 & 0.0904 \\
\hline 23 & 4.7405 & 0.2109 & 53.4361 & 0.0187 & 11.2722 & 0.0887 \\
\hline 24 & 5.0724 & 0.1971 & 58.1767 & 0.0172 & 11.4693 & 0.0872 \\
\hline 25 & 5.4274 & 0.1842 & 63.2490 & 0.0158 & 11.6536 & 0.0858 \\
\hline 26 & 5.8074 & 0.1722 & 68.6765 & 0.0146 & 11.8258 & 0.0846 \\
\hline 27 & 6.2139 & 0.1609 & 74.4838 & 0.0134 & 11.9867 & 0.0834 \\
\hline 28 & 6.6488 & 0.1504 & 80.6977 & 0.0124 & 12.1371 & 0.0824 \\
\hline 29 & 7.1143 & 0.1406 & 87.3465 & 0.0114 & $12.27 \pi$ & 0.0814 \\
\hline 30 & 7.6123 & 0.1314 & 94.4608 & 0.0106 & 12.4090 & 0.0806 \\
\hline 31 & 8.1451 & 0.1228 & 102.0730 & 0.0098 & 12.5318 & 0.0798 \\
\hline 32 & 8.7153 & 0.1147 & 110.2182 & 0.0091 & 12.6466 & 0.0791 \\
\hline 33 & 9.3253 & 0.1072 & 118.9334 & 0.0084 & 12.7538 & 0.0784 \\
\hline 34 & 9.9781 & 0.1002 & 128.2588 & 0.0078 & 12.8540 & 0.0778 \\
\hline 35 & 10.6766 & 0.0937 & 138.2369 & 0.0072 & 12.9477 & 0.0772 \\
\hline 36 & 11.4239 & 0.0875 & 148.9135 & 0.0067 & 13.0352 & 0.0767 \\
\hline 37 & 12.2236 & 0.0818 & 160.3374 & 0.0062 & 13.1170 & 0.0762 \\
\hline 38 & 13.0793 & 0.0765 & 172.5610 & 0.0058 & 13.1935 & 0.0758 \\
\hline 39 & 13.9948 & 0.0715 & 185.6403 & 0.0054 & 13.2649 & 0.0754 \\
\hline 40 & 14.9745 & 0.0668 & 199.6351 & 0.0050 & 13.3317 & 0.0750 \\
\hline 45 & 21.0025 & 0.0476 & 285.7493 & 0.0035 & 13.6055 & 0.0735 \\
\hline 48 & 25.7289 & 0.0389 & 353.2701 & 0.0028 & 13.7305 & 0.0728 \\
\hline 50 & 29.4570 & 0.0339 & 406.5289 & 0.0025 & 13.8007 & 0.0725 \\
\hline 54 & 38.6122 & 0.0259 & 537.3164 & 0.0019 & 13.9157 & 0.0719 \\
\hline 60 & 57.9464 & 0.0173 & 813.5204 & 0.0012 & 14.0392 & 0.0712 \\
\hline
\end{tabular}




\section{Compound Intereste Table for: $\mathrm{i}=\mathbf{8} \%$}

\begin{tabular}{|c|c|c|c|c|c|c|}
\hline & \multicolumn{2}{|c|}{ Single Payment } & \multicolumn{4}{|c|}{ Uniform Series } \\
\hline & $\begin{array}{c}\text { Compound Amount } \\
\text { Factor }\end{array}$ & $\begin{array}{c}\begin{array}{c}\text { Present Worth } \\
\text { Factor }\end{array} \\
\end{array}$ & $\begin{array}{c}\text { Compound Amount } \\
\text { Factor }\end{array}$ & Sinking Fund Factor & $\begin{array}{c}\text { Present Worth } \\
\text { Factor }\end{array}$ & $\begin{array}{c}\text { Capital Recovery } \\
\text { Factor }\end{array}$ \\
\hline $\mathrm{n}$ & $\begin{array}{c}\text { To find } F \text { when given } \\
\text { a } \mathrm{P} \\
(\mathrm{F} / \mathrm{P}, \mathrm{i}, \mathrm{n})\end{array}$ & $\begin{array}{c}\text { To find } \mathrm{P} \text { when given } \\
\text { an } \mathrm{F} \\
\text { (P/F, } \mathrm{i}, \mathrm{n})\end{array}$ & $\begin{array}{c}\text { To find } F \text { when given } \\
\text { an } A \\
(F / A, i, n)\end{array}$ & $\begin{array}{c}\text { To find } \mathrm{A} \text { when given } \\
\text { an } \mathrm{F} \\
\text { (A/F, i, n) }\end{array}$ & $\begin{array}{c}\text { To find } P \text { when given } \\
\text { an } A \\
(P / A, i, n)\end{array}$ & $\begin{array}{c}\text { To find } A \text { when given } \\
\text { aP } \\
\text { (AVP, } i, n)\end{array}$ \\
\hline 1 & 1.0800 & 0.9259 & 1.0000 & 1.0000 & 0.9259 & 1.0800 \\
\hline 2 & 1.1664 & 0.8573 & 2.0800 & 0.4808 & 1.7833 & 0.5608 \\
\hline 3 & 1.2597 & 0.7938 & 3.2464 & 0.3080 & 2.5771 & 0.3880 \\
\hline 4 & 1.3605 & 0.7350 & 4.5061 & 0.2219 & 3.3121 & 0.3019 \\
\hline 5 & 1.4693 & 0.6806 & 5.8666 & 0.1705 & 3.9927 & 0.2505 \\
\hline 6 & 1.5869 & 0.6302 & 7.3359 & 0.1363 & 4.6229 & 0.2163 \\
\hline 7 & 1.7138 & 0.5835 & 8.9228 & 0.1121 & 5.2064 & 0.1921 \\
\hline 8 & 1.8509 & 0.5403 & 10.6366 & 0.0940 & 5.7466 & 0.1740 \\
\hline 9 & 1.9990 & 0.5002 & 12.4876 & 0.0801 & 6.2469 & 0.1601 \\
\hline 10 & 2.1589 & 0.4632 & 14.4866 & 0.0690 & 6.7101 & 0.1490 \\
\hline 11 & 2.3316 & 0.4289 & 16.6455 & 0.0601 & 7.1390 & 0.1401 \\
\hline 12 & 2.5182 & 0.3971 & 18.9771 & 0.0527 & 7.5361 & 0.1327 \\
\hline 13 & 2.7196 & 0.3677 & 21.4953 & 0.0465 & 7.9038 & 0.1265 \\
\hline 14 & 2.9372 & 0.3405 & 24.2149 & 0.0413 & 8.2442 & 0.1213 \\
\hline 15 & 3.1722 & 0.3152 & 27.1521 & 0.0368 & 8.5595 & 0.1168 \\
\hline 16 & 3.4259 & 0.2919 & 30.3243 & 0.0330 & 8.8514 & 0.1130 \\
\hline 17 & 3.7000 & 0.2703 & 33.7502 & 0.0296 & 9.1216 & 0.1096 \\
\hline 18 & 3.9960 & 0.2502 & 37.4502 & 0.0267 & 9.3719 & 0.1067 \\
\hline 19 & 4.3157 & 0.2317 & 41.4463 & 0.0241 & 9.6036 & 0.1041 \\
\hline 20 & 4.6610 & 0.2145 & 45.7620 & 0.0219 & 9.8181 & 0.1019 \\
\hline 21 & 5.0338 & 0.1987 & 50.4229 & 0.0198 & 10.0168 & 0.0998 \\
\hline 22 & 5.4365 & 0.1839 & 55.4568 & 0.0180 & 10.2007 & 0.0980 \\
\hline 23 & 5.8715 & 0.1703 & 60.8933 & 0.0164 & 10.3711 & 0.0964 \\
\hline 24 & 6.3412 & 0.157 & 66.7648 & 0.0150 & 10.5288 & 0.0950 \\
\hline 25 & 6.8485 & 0.1460 & 73.1059 & 0.0137 & 10.6748 & 0.0937 \\
\hline 26 & 7.3964 & 0.1352 & 79.9544 & 0.0125 & 10.8100 & 0.0925 \\
\hline 27 & 7.9881 & 0.1252 & 87.3508 & 0.0114 & 10.9352 & 0.0914 \\
\hline 28 & 8.6271 & 0.1159 & 95.3388 & 0.0105 & 11.0511 & 0.0905 \\
\hline 29 & 9.3173 & 0.1073 & 103.9659 & 0.0096 & 11.1584 & 0.0896 \\
\hline 30 & 10.0627 & 0.0994 & 113.2832 & 0.0088 & 11.2578 & 0.0888 \\
\hline 31 & 10.8677 & 0.0920 & 123.3459 & 0.0081 & 11.3498 & 0.0881 \\
\hline 32 & 11.7371 & 0.0852 & 134.2135 & 0.0075 & 11.4350 & 0.0875 \\
\hline 33 & 12.6760 & 0.0789 & 145.9506 & 0.0069 & 11.5139 & 0.0869 \\
\hline 34 & 13.6901 & 0.0730 & 158.6267 & 0.0063 & 11.5869 & 0.0863 \\
\hline 35 & 14.7853 & 0.0676 & 172.3168 & 0.0058 & 11.6546 & 0.0858 \\
\hline 36 & 15.9682 & 0.0626 & 187.1021 & 0.0053 & 11.7172 & 0.0853 \\
\hline 37 & 17.2456 & 0.0580 & 203.0703 & 0.0049 & 11.7752 & 0.0849 \\
\hline 38 & 18.6253 & 0.0537 & 220.3159 & 0.0045 & 11.8289 & 0.0845 \\
\hline 39 & 20.1153 & 0.0497 & 238.9412 & 0.0042 & 11.8786 & 0.0842 \\
\hline 40 & 21.7245 & 0.0460 & 259.0565 & 0.0039 & 11.9246 & 0.0839 \\
\hline 45 & 31.9204 & 0.0313 & 386.5056 & 0.0026 & 12.1084 & 0.0826 \\
\hline 48 & 40.2106 & 0.0249 & 490.1322 & 0.0020 & 12.1891 & 0.0820 \\
\hline 50 & 46.9016 & 0.0213 & 573.7702 & 0.0017 & 12.2335 & 0.0817 \\
\hline 54 & 63.8091 & 0.0157 & 785.1141 & 0.0013 & 12.3041 & 0.0813 \\
\hline 60 & 101.2571 & 0.0099 & 1253.2133 & 0.0008 & 12.3766 & 0.0808 \\
\hline
\end{tabular}


Compound Intereste Table for: $\mathrm{i}=\mathbf{9 \%}$

\begin{tabular}{|c|c|c|c|c|c|c|}
\hline & \multicolumn{2}{|c|}{ Single Payment } & \multicolumn{4}{|c|}{ Uniform Series } \\
\hline & $\begin{array}{l}\text { Compound Arrount } \\
\text { Factor }\end{array}$ & $\begin{array}{l}\text { Present Worth } \\
\text { Factor }\end{array}$ & $\begin{array}{l}\text { Compound Amount } \\
\text { Factor }\end{array}$ & Sinking Fund Factor & $\begin{array}{l}\text { Present Worth } \\
\text { Factor }\end{array}$ & $\begin{array}{c}\text { Capital Recovery } \\
\text { Factor }\end{array}$ \\
\hline n & $\begin{array}{c}\text { To find } F \text { when given } \\
\text { a } P \\
(F / P, i, n)\end{array}$ & $\begin{array}{c}\text { To find } P \text { when given } \\
\text { an } F \\
(P / F, i, n)\end{array}$ & $\begin{array}{c}\text { To find } F \text { when given } \\
\text { an } A \\
(F / A, i, n)\end{array}$ & $\begin{array}{c}\text { To find } A \text { when given } \\
\text { an } F \\
(A / F, i, n)\end{array}$ & $\begin{array}{c}\text { To find } P \text { when given } \\
\text { an } A \\
(P / A, i, n)\end{array}$ & $\begin{array}{c}\text { To find } A \text { when given } \\
\text { a P } \\
\left.\text { (A/P, } i_{1}, n\right)\end{array}$ \\
\hline 1 & 1.0900 & 0.9174 & 1.0000 & 1.0000 & 0.9174 & 1.0900 \\
\hline 2 & 1.1881 & 0.8417 & 2.0900 & 0.4785 & 1.7591 & 0.5685 \\
\hline 3 & 1.2950 & 0.7722 & 3.2781 & 0.3051 & 2.5313 & 0.3951 \\
\hline 4 & 1.4116 & 0.7084 & 4.5731 & 0.2187 & 3.2397 & 0.3087 \\
\hline 5 & 1.5386 & 0.6499 & 5.9847 & 0.1671 & 3.8897 & 0.2571 \\
\hline 6 & 1.6771 & 0.5963 & 7.5233 & 0.1329 & 4.4859 & 0.2229 \\
\hline 7 & 1.8280 & 0.5470 & 9.2004 & 0.1087 & 5.0330 & 0.1987 \\
\hline 8 & 1.9926 & 0.5019 & 11.0285 & 0.0907 & 5.5348 & 0.1807 \\
\hline 9 & 2.1719 & 0.4604 & 13.0210 & 0.0768 & 5.9952 & 0.1668 \\
\hline 10 & 2.3674 & 0.4224 & 15.1929 & 0.0658 & 6.4177 & 0.1558 \\
\hline 11) & 2.5804 & 0.3875 & 17.5603 & 0.0569 & 6.8052 & 0.1469 \\
\hline 12 & 2.8127 & 0.3555 & 20.1407 & 0.0497 & 7.1607 & 0.1397 \\
\hline 13 & 3.0658 & 0.3262 & 22.9534 & 0.0436 & 7.4869 & 0.1336 \\
\hline 14 & 3.3417 & 0.2992 & 26.0192 & 0.0384 & 7.7862 & 0.1284 \\
\hline 15 & 3.6425 & 0.2745 & 29.3609 & 0.0341 & 8.0607 & 0.1241 \\
\hline 16 & 3.9703 & 0.2519 & 33.0034 & 0.0303 & 8.3126 & 0.1203 \\
\hline 17 & 4.3276 & 0.2311 & 36.9737 & 0.0270 & 8.5436 & 0.1170 \\
\hline 18 & 4.7171 & 0.2120 & 41.3013 & 0.0242 & 8.7556 & 0.1142 \\
\hline 19 & 5.1417 & 0.1945 & 46.0185 & 0.0217 & 8.9501 & 0.1117 \\
\hline 20 & 5.6044 & 0.1784 & 51.1601 & 0.0195 & 9.1285 & 0.1095 \\
\hline 21 & 6.1088 & 0.1637 & 56.7645 & 0.0176 & 9.2922 & 0.1076 \\
\hline 22 & 6.6586 & 0.1502 & 62.8733 & 0.0159 & 9.4424 & 0.1059 \\
\hline 23 & 7.2579 & 0.1378 & 69.5319 & 0.0144 & 9.5802 & 0.1044 \\
\hline 24 & 7.9111 & 0.1264 & 76.7898 & 0.0130 & 9.7066 & 0.1030 \\
\hline 25 & 8.6231 & 0.1160 & 84.7009 & 0.0118 & 9.8226 & 0.1018 \\
\hline 26 & 9.3992 & 0.1064 & 93.3240 & 0.0107 & 9.9290 & 0.1007 \\
\hline 27 & 10.2451 & 0.0976 & 102.7231 & 0.0097 & 10.0266 & 0.0997 \\
\hline 28 & 11.1671 & 0.0895 & 112.9682 & 0.0089 & 10.1161 & 0.0989 \\
\hline 29 & 12.1722 & 0.0822 & 124.1354 & 0.0081 & 10.1983 & 0.0981 \\
\hline 30 & 13.2677 & 0.0754 & 136.3075 & 0.0073 & 10.2737 & 0.0973 \\
\hline 31 & 14.4618 & 0.0691 & 149.5752 & 0.0067 & 10.3428 & 0.0967 \\
\hline 32 & 15.7633 & 0.0634 & 164.0370 & 0.0061 & 10.4062 & 0.0961 \\
\hline 33 & 17.1820 & 0.0582 & 179.8003 & 0.0056 & 10.4644 & 0.0956 \\
\hline 34 & 18.7284 & 0.0534 & 196.9823 & 0.0051 & 10.5178 & 0.0951 \\
\hline 35 & 20.4140 & 0.0490 & 215.7108 & 0.0046 & 10.5668 & 0.0946 \\
\hline 36 & 22.2512 & 0.0449 & 236.1247 & 0.0042 & 10.6118 & 0.0942 \\
\hline 37 & 24.2538 & 0.0412 & 258.3759 & 0.0039 & 10.6530 & 0.0939 \\
\hline 38 & 26.4367 & 0.0378 & 282.6298 & 0.0035 & 10.6908 & 0.0935 \\
\hline 39) & 28.8160 & 0.0347 & 309.0665 & 0.0032 & 10.7255 & 0.0932 \\
\hline 40 & 31.4094 & 0.0318 & 337.8824 & 0.0030 & 10.7574 & 0.0930 \\
\hline 45 & 48.3273 & 0.0207 & 525.8587 & 0.0019 & 10.8812 & 0.0919 \\
\hline 48 & 62.5852 & 0.0160 & 684.2804 & 0.0015 & 10.9336 & 0.0915 \\
\hline 50 & 74.3575 & 0.0134 & 815.0836 & 0.0012 & 10.9617 & 0.0912 \\
\hline 54 & 104.9617 & 0.0095 & 1155.1301 & 0.0009 & 11.0053 & 0.0909 \\
\hline 60 & 176.0313 & 0.0057 & 1944.7921 & 0.0005 & 11.0480 & 0.0905 \\
\hline
\end{tabular}


Compound Intereste Table for: $\mathrm{i}=10 \%$

\begin{tabular}{|c|c|c|c|c|c|c|}
\hline & \multicolumn{2}{|c|}{ Single Payment } & \multicolumn{4}{|c|}{ Uhiform Series } \\
\hline & $\begin{array}{l}\text { Compound Amount } \\
\text { Factor }\end{array}$ & $\begin{array}{c}\text { Present Worth } \\
\text { Factor }\end{array}$ & $\begin{array}{l}\text { Compound Amount } \\
\text { Factor }\end{array}$ & Sinking Fund Factor & $\begin{array}{c}\text { Present Worth } \\
\text { Factor }\end{array}$ & $\begin{array}{l}\text { Capital Recovery } \\
\text { Factor }\end{array}$ \\
\hline $\mathbf{n}$ & $\begin{array}{c}\text { To find } F \text { when given } \\
\text { a } \mathrm{P} \\
(\mathrm{F} / \mathrm{P}, \mathrm{i}, \mathrm{n})\end{array}$ & $\begin{array}{c}\text { To find } P \text { when given } \\
\text { an } F \\
\text { (P/F, i, n) }\end{array}$ & $\begin{array}{c}\text { To find } F \text { when given } \\
\text { an } A \\
\text { (F/A, } \mathrm{i}, \mathrm{n})\end{array}$ & $\begin{array}{c}\text { To find } A \text { when given } \\
\text { an } F \\
\text { (AVF, } i, n \text { ) }\end{array}$ & $\begin{array}{c}\text { To find } P \text { when given } \\
\text { an } A \\
\text { (PIA, }, \mathrm{n} \text { ) }\end{array}$ & $\begin{array}{c}\text { To find } A \text { when given } \\
\text { aP } \\
\text { (AP, } i, n)\end{array}$ \\
\hline 1 & 1.1000 & 0.9091 & 1.0000 & 1.0000 & 0.9091 & 1.1000 \\
\hline 2 & 1.2100 & 0.8264 & 2.1000 & 0.4762 & 1.7355 & 0.5762 \\
\hline 3 & 1.3310 & 0.7513 & 3.3100 & 0.3021 & 2.4869 & 0.4021 \\
\hline 4 & 1.4641 & 0.6830 & 4.6410 & 0.2155 & 3.1699 & 0.3155 \\
\hline 5 & 1.6105 & 0.6209 & 6.1051 & 0.1638 & 3.7908 & 0.2638 \\
\hline 6 & 1.7716 & 0.5645 & 7.7156 & 0.1296 & 4.3553 & 0.2296 \\
\hline 7 & 1.9487 & 0.5132 & 9.4872 & 0.1054 & 4.8684 & 0.2054 \\
\hline 8 & 2.1436 & 0.4665 & 11.4359 & 0.0874 & 5.3349 & 0.1874 \\
\hline 9 & 2.3579 & 0.4241 & 13.5795 & 0.0736 & 5.7590 & 0.1736 \\
\hline 10 & 2.5937 & 0.3855 & 15.9374 & 0.0627 & 6.1446 & 0.1627 \\
\hline 11 & 2.8531 & 0.3505 & 18.5312 & 0.0540 & 6.4951 & 0.1540 \\
\hline 12 & 3.1384 & 0.3186 & 21.3843 & 0.0468 & 6.8137 & 0.1468 \\
\hline 13 & 3.4523 & 0.2897 & 24.5227 & 0.0408 & 7.1034 & 0.1408 \\
\hline 14 & 3.7975 & 0.2633 & 27.9750 & 0.0357 & 7.3667 & 0.1357 \\
\hline 15 & 4.1772 & 0.2394 & 31.7725 & 0.0315 & 7.6061 & 0.1315 \\
\hline 16 & 4.5950 & 0.2176 & 35.9497 & 0.0278 & 7.8237 & 0.1278 \\
\hline 17 & 5.0545 & 0.1978 & 40.5447 & 0.0247 & 8.0216 & 0.1247 \\
\hline 18 & 5.5599 & 0.1799 & 45.5992 & 0.0219 & 8.2014 & 0.1219 \\
\hline 19 & 6.1159 & 0.1635 & 51.1591 & 0.0195 & 8.3649 & 0.1195 \\
\hline 20 & 6.7275 & 0.1486 & 57.2750 & 0.0175 & 8.5136 & 0.1175 \\
\hline 21 & 7.4002 & 0.1351 & 64.0025 & 0.0156 & 8.6487 & 0.1156 \\
\hline 22 & 8.1403 & 0.1228 & 71.4027 & 0.0140 & 8.7715 & 0.1140 \\
\hline 23 & 8.9543 & 0.1117 & 79.5430 & 0.0126 & 8.8832 & 0.1126 \\
\hline 24 & 9.8497 & 0.1015 & 88.4973 & 0.0113 & 8.9847 & 0.1113 \\
\hline 25 & 10.8347 & 0.0923 & 98.3471 & 0.0102 & 9.0770 & 0.1102 \\
\hline 26 & 11.9182 & 0.0839 & 109.1818 & 0.0092 & 9.1609 & 0.1092 \\
\hline 27 & 13.1100 & 0.0763 & 121.0999 & 0.0083 & 9.2372 & 0.1083 \\
\hline 28 & 14.4210 & 0.0693 & 134.2099 & 0.0075 & 9.3066 & 0.1075 \\
\hline 29 & 15.8631 & 0.0630 & 148.6309 & 0.0067 & 9.3696 & 0.1067 \\
\hline 30 & 17.4494 & 0.0573 & 164.4940 & 0.0061 & 9.4269 & 0.1061 \\
\hline 31 & 19.1943 & 0.0521 & 181.9434 & 0.0055 & 9.4790 & 0.1055 \\
\hline 32 & 21.1138 & 0.0474 & 201.1378 & 0.0050 & 9.5264 & 0.1050 \\
\hline 33 & 23.2252 & 0.0431 & 222.2515 & 0.0045 & 9.5694 & 0.1045 \\
\hline 34 & 25.5477 & 0.0391 & 245.4767 & 0.0041 & 9.6086 & 0.1041 \\
\hline 35 & 28.1024 & 0.0356 & 271.0244 & 0.0037 & 9.6442 & 0.1037 \\
\hline 36 & 30.9127 & 0.0323 & 299.1268 & 0.0033 & 9.6765 & 0.1033 \\
\hline 37 & 34.0039 & 0.0294 & 330.0395 & 0.0030 & 9.7059 & 0.1030 \\
\hline 38 & 37.4043 & 0.0267 & 364.0434 & 0.0027 & 9.7327 & 0.1027 \\
\hline 39 & 41.1448 & 0.0243 & 401.4478 & 0.0025 & 9.7570 & 0.1025 \\
\hline 40 & 45.2593 & 0.0221 & 442.5926 & 0.0023 & 9.7791 & 0.1023 \\
\hline 45 & 72.8905 & 0.0137 & 718.9048 & 0.0014 & 9.8628 & 0.1014 \\
\hline 48 & 97.0172 & 0.0103 & 960.1723 & 0.0010 & 9.8969 & 0.1010 \\
\hline 50 & 117.3909 & 0.0085 & 1163.9085 & 0.0009 & 9.9148 & 0.1009 \\
\hline 54 & 171.8719 & 0.0058 & 1708.7195 & 0.0006 & 9.9418 & 0.1006 \\
\hline 60 & 304.4816 & 0.0033 & 3034.8164 & 0.0003 & 9.9672 & 0.1003 \\
\hline
\end{tabular}


Compound Intereste Table for: $\mathrm{i}=12 \%$

\begin{tabular}{|c|c|c|c|c|c|c|}
\hline & \multicolumn{2}{|c|}{ Single Payment } & \multicolumn{4}{|c|}{ Uniform Series } \\
\hline & $\begin{array}{l}\text { Compound Amount } \\
\text { Factor }\end{array}$ & $\begin{array}{l}\text { Present Worth } \\
\text { Factor }\end{array}$ & $\begin{array}{l}\text { Compound Amount } \\
\text { Factor }\end{array}$ & Sinking Fund Factor & $\begin{array}{l}\text { Present Worth } \\
\text { Factor }\end{array}$ & $\begin{array}{c}\text { Capital Recovery } \\
\text { Factor }\end{array}$ \\
\hline n) & $\begin{array}{c}\text { To find } F \text { when given } \\
\text { aP } \\
(\mathrm{F} / \mathrm{P}, \mathrm{i}, \mathrm{n})\end{array}$ & $\begin{array}{c}\text { To find } P \text { when given } \\
\text { an } F \\
(P / F, i, n)\end{array}$ & $\begin{array}{c}\text { To find } F \text { when given } \\
\text { an } A \\
(F / A, i, n)\end{array}$ & $\begin{array}{c}\text { To find } A \text { when given } \\
\text { an } F \\
(\mathrm{~A} F, \mathbf{i}, \mathrm{n})\end{array}$ & $\begin{array}{c}\text { To find } P \text { when given } \\
\text { an } A \\
\text { (P/A, } i, n)\end{array}$ & $\begin{array}{c}\text { To find } A \text { when given } \\
\text { a } P \\
\text { (AvP, i, n) }\end{array}$ \\
\hline 1 & 1.1200 & 0.8929 & 1.0000 & 1.0000 & 0.8929 & 1.1200 \\
\hline 2 & 1.2544 & 0.7972 & 2.1200 & 0.4717 & 1.6901 & 0.5917 \\
\hline 3 & 1.4049 & 0.7118 & 3.3744 & 0.2963 & 2.4018 & 0.4163 \\
\hline 4 & 1.5735 & 0.6355 & 4.7793 & 0.2092 & 3.0373 & 0.3292 \\
\hline 5 & 1.7623 & 0.5674 & 6.3528 & 0.1574 & 3.6048 & 0.2774 \\
\hline 6 & 1.9738 & 0.5066 & 8.1152 & 0.1232 & 4.1114 & 0.2432 \\
\hline 7 & 2.2107 & 0.4523 & 10.0890 & 0.0991 & 4.5638 & 0.2191 \\
\hline 8 & 2.4760 & 0.4039 & 12.2997 & 0.0813 & 4.9676 & 0.2013 \\
\hline 9 & 2.7731 & 0.3606 & 14.7757 & 0.0677 & 5.3282 & 0.1877 \\
\hline 10 & 3.1058 & 0.3220 & 17.5487 & 0.0570 & 5.6502 & 0.1770 \\
\hline 11 & 3.4785 & 0.2875 & 20.6546 & 0.0484 & 5.9377 & 0.1684 \\
\hline 12 & 3.8960 & 0.2567 & 24.1331 & 0.0414 & 6.1944 & 0.1614 \\
\hline 13 & 4.3635 & 0.2292 & 28.0291 & 0.0357 & 6.4235 & 0.1557 \\
\hline 14 & 4.8871 & 0.2046 & 32.3926 & 0.0309 & 6.6282 & 0.1509 \\
\hline 15 & 5.4736 & 0.1827 & 37.2797 & 0.0268 & 6.8109 & 0.1468 \\
\hline 16 & 6.1304 & 0.1631 & 42.7533 & 0.0234 & 6.9740 & 0.1434 \\
\hline 17 & 6.8660 & 0.1456 & 48.8837 & 0.0205 & 7.1196 & 0.1405 \\
\hline 18 & 7.6900 & 0.1300 & 55.7497 & 0.0179 & 7.2497 & 0.1379 \\
\hline 19 & 8.6128 & 0.1161 & 63.4397 & 0.0158 & 7.3658 & 0.1358 \\
\hline 20 & 9.6463 & 0.1037 & 72.0524 & 0.0139 & 7.4694 & 0.1339 \\
\hline 21 & 10.8038 & 0.0926 & 81.6987 & 0.0122 & 7.5620 & 0.1322 \\
\hline 22 & 12.1003 & 0.0826 & 92.5026 & 0.0108 & 7.6446 & 0.1308 \\
\hline 23 & 13.5523 & 0.0738 & 104.6029 & 0.0096 & 7.7184 & 0.1296 \\
\hline 24 & 15.1786 & 0.0659 & 118.1552 & 0.0085 & 7.7843 & 0.1285 \\
\hline 25 & 17.0001 & 0.0588 & 133.3339 & 0.0075 & 7.8431 & 0.1275 \\
\hline 26 & 19.0401 & 0.0525 & 150.3339 & 0.0067 & 7.8957 & 0.1267 \\
\hline 27 & 21.3249 & 0.0469 & 169.3740 & 0.0059 & 7.9426 & 0.1259 \\
\hline 28 & 23.8839 & 0.0419 & 190.6989 & 0.0052 & 7.9844 & 0.1252 \\
\hline 29 & 26.7499 & 0.0374 & 214.5828 & 0.0047 & 8.0218 & 0.1247 \\
\hline 30 & 29.9599 & 0.0334 & 241.3327 & 0.0041 & 8.0552 & 0.1241 \\
\hline 31 & 33.5551 & 0.0298 & 271.2926 & 0.0037 & 8.0850 & 0.1237 \\
\hline 32 & 37.5817 & 0.0266 & 304.8477 & 0.0033 & 8.1116 & 0.1233 \\
\hline 33 & 42.0915 & 0.0238 & 342.4294 & 0.0029 & 8.1354 & 0.1229 \\
\hline 34 & 47.1425 & 0.0212 & 384.5210 & 0.0026 & 8.1566 & 0.1226 \\
\hline 35 & 52.7996 & 0.0189 & 431.6635 & 0.0023 & 8.1755 & 0.1223 \\
\hline 36 & 59.1356 & 0.0169 & 484.4631 & 0.0021 & 8.1924 & 0.1221 \\
\hline 37 & 66.2318 & 0.0151 & 543.5987 & 0.0018 & 8.2075 & 0.1218 \\
\hline 38 & 74.1797 & 0.0135 & 609.8305 & 0.0016 & 8.2210 & 0.1216 \\
\hline 39 & 83.0812 & 0.0120 & 684.0102 & 0.0015 & 8.2330 & 0.1215 \\
\hline 40 & 93.0510 & 0.0107 & 767.0914 & 0.0013 & 8.2438 & 0.1213 \\
\hline 45 & 163.9876 & 0.0061 & 1358.2300 & 0.0007 & 8.2825 & 0.1207 \\
\hline 48 & 230.3908 & 0.0043 & 1911.5898 & 0.0005 & 8.2972 & 0.1205 \\
\hline 50 & 289.0022 & 0.0035 & 2400.0182 & 0.0004 & 8.3045 & 0.1204 \\
\hline 54) & 454.7505 & 0.0022 & 3781.2545 & 0.0003 & 8.3150 & 0.1203 \\
\hline 60 & 897.5969 & 0.0011 & 7471.6411 & 0.0001 & 8.3240 & 0.1201 \\
\hline
\end{tabular}




\section{Compound Intereste Table for: $\mathrm{i}=15 \%$}

\begin{tabular}{|c|c|c|c|c|c|c|}
\hline & \multicolumn{2}{|c|}{ Single Payment } & \multicolumn{4}{|c|}{ Uniform Series } \\
\hline & $\begin{array}{l}\text { Compound Amount } \\
\text { Factor }\end{array}$ & $\begin{array}{c}\text { Present Worth } \\
\text { Factor }\end{array}$ & $\begin{array}{c}\text { Compound Amount } \\
\text { Factor }\end{array}$ & Sinking Fund Factor & $\begin{array}{c}\text { Present Worth } \\
\text { Factor }\end{array}$ & $\begin{array}{l}\text { Capital Recovery } \\
\text { Factor }\end{array}$ \\
\hline $\mathbf{n}$ & $\begin{array}{c}\text { To find } F \text { when given } \\
\text { a } P \\
\text { (F/P, } i, n)\end{array}$ & $\begin{array}{c}\text { To find } P \text { when given } \\
\text { an } F \\
\text { (P/F, } i, n)\end{array}$ & $\begin{array}{c}\text { To find } F \text { when given } \\
\text { an } A \\
(F / A, i, n)\end{array}$ & $\begin{array}{c}\text { To find } A \text { when given } \\
\text { an } F \\
\text { (AVF, i, n) }\end{array}$ & $\begin{array}{c}\text { To find } P \text { when given } \\
\text { an } A \\
\text { (P/A, }, \mathrm{i}, \mathrm{n})\end{array}$ & $\begin{array}{c}\text { To find } A \text { when giver } \\
\text { a } P \\
\text { (AVP, }, n \text { ) }\end{array}$ \\
\hline 1 & 1.1500 & 0.8696 & 1.0000 & 1.0000 & 0.8696 & 1.1500 \\
\hline 2 & 1.3225 & 0.7561 & 2.1500 & 0.4651 & 1.6257 & 0.6151 \\
\hline 3 & 1.5209 & 0.6575 & 3.4725 & 0.2880 & 2.2832 & 0.4380 \\
\hline 4 & 1.7490 & 0.5718 & 4.9934 & 0.2003 & 2.8550 & 0.3503 \\
\hline 5 & 2.0114 & 0.4972 & 6.7424 & 0.1483 & 3.3522 & 0.2983 \\
\hline 6 & 2.3131 & 0.4323 & 8.7537 & 0.1142 & 3.7845 & 0.2642 \\
\hline 7 & 2.6600 & 0.3759 & 11.0668 & 0.0904 & 4.1604 & 0.2404 \\
\hline 8 & 3.0590 & 0.3269 & 13.7268 & 0.0729 & 4.4873 & 0.2229 \\
\hline 9 & 3.5179 & 0.2843 & 16.7858 & 0.0596 & 4.7716 & 0.2096 \\
\hline 10 & 4.0456 & 0.2472 & 20.3037 & 0.0493 & 5.0188 & 0.1993 \\
\hline 11 & 4.6524 & 0.2149 & 24.3493 & 0.0411 & 5.2337 & 0.1911 \\
\hline 12 & 5.3503 & 0.1869 & 29.0017 & 0.0345 & 5.4206 & 0.1845 \\
\hline 13 & 6.1528 & 0.1625 & 34.3519 & 0.0291 & 5.5831 & 0.1791 \\
\hline 14 & 7.0757 & 0.1413 & 40.5047 & 0.0247 & 5.7245 & 0.1747 \\
\hline 15 & 8.1371 & 0.1229 & 47.5804 & 0.0210 & 5.8474 & 0.1710 \\
\hline 16 & 9.3576 & 0.1069 & 55.7175 & 0.0179 & 5.9542 & 0.1679 \\
\hline 17 & 10.7613 & 0.0929 & 65.0751 & 0.0154 & 6.0472 & 0.1654 \\
\hline 18 & 12.3755 & 0.0808 & 75.8364 & 0.0132 & 6.1280 & 0.1632 \\
\hline 19 & 14.2318 & 0.0703 & 88.2118 & 0.0113 & 6.1982 & 0.1613 \\
\hline 20 & 16.3665 & 0.0611 & 102.4436 & 0.0098 & 6.2593 & 0.1598 \\
\hline 21 & 18.8215 & 0.0531 & 118.8101 & 0.0084 & 6.3125 & 0.1584 \\
\hline 22 & 21.6447 & 0.0462 & 137.6316 & 0.0073 & 6.3587 & 0.1573 \\
\hline 23 & 24.8915 & 0.0402 & 159.2764 & 0.0063 & 6.3988 & 0.1563 \\
\hline 24 & 28.6252 & 0.0349 & 184.1678 & 0.0054 & 6.4338 & 0.1554 \\
\hline 25 & 32.9190 & 0.0304 & 212.7930 & 0.0047 & 6.4641 & 0.1547 \\
\hline 26 & 37.8568 & 0.0264 & 245.7120 & 0.0041 & 6.4906 & 0.1541 \\
\hline 27 & 43.5353 & 0.0230 & 283.5688 & 0.0035 & 6.5135 & 0.1535 \\
\hline 28 & 50.0656 & 0.0200 & 327.1041 & 0.0031 & 6.5335 & 0.1531 \\
\hline 29 & 57.5755 & 0.0174 & 377.1697 & 0.0027 & 6.5509 & 0.1527 \\
\hline 30 & 66.2118 & 0.0151 & 434.7451 & 0.0023 & 6.5660 & 0.1523 \\
\hline 31 & 76.1435 & 0.0131 & 500.9569 & 0.0020 & 6.5791 & 0.1520 \\
\hline 32 & 87.5651 & 0.0114 & 577.1005 & 0.0017 & 6.5905 & 0.1517 \\
\hline 33 & 100.6998 & 0.0099 & 664.6655 & 0.0015 & 6.6005 & 0.1515 \\
\hline 34 & 115.8048 & 0.0086 & 765.3654 & 0.0013 & 6.6091 & 0.1513 \\
\hline 35 & 133.1755 & 0.0075 & 881.1702 & 0.0011 & 6.6166 & 0.1511 \\
\hline 36 & 153.1519 & 0.0065 & 1014.3457 & 0.0010 & 6.6231 & 0.1510 \\
\hline 37 & 176.1246 & 0.0057 & 1167.4975 & 0.0009 & 6.6288 & 0.1509 \\
\hline 38 & 202.5433 & 0.0049 & 1343.6222 & 0.0007 & 6.6338 & 0.1507 \\
\hline 39 & 232.9248 & 0.0043 & 1546.1655 & 0.0006 & 6.6380 & 0.1506 \\
\hline 40 & 267.8635 & 0.0037 & 1779.0903 & 0.0006 & 6.6418 & 0.1506 \\
\hline 45 & 538.7693 & 0.0019 & 3585.1285 & 0.0003 & 6.6543 & 0.1503 \\
\hline 48 & 819.4007 & 0.0012 & 5456.0047 & 0.0002 & 6.6585 & 0.1502 \\
\hline 50 & 1083.6574 & 0.0009 & 7217.7163 & 0.0001 & 6.6605 & 0.1501 \\
\hline 54 & 1895.3236 & 0.0005 & 12628.8243 & 0.0001 & 6.6631 & 0.1501 \\
\hline 60 & 4383.9987 & 0.0002 & 29219.9916 & 0.0000 & 6.6651 & 0.1500 \\
\hline
\end{tabular}


Compound Intereste Table for: $i=18 \%$

\begin{tabular}{|c|c|c|c|c|c|c|}
\hline & \multicolumn{2}{|c|}{ Single Payment } & \multicolumn{4}{|c|}{$\begin{array}{l}\text { Uniform Series } \\
\end{array}$} \\
\hline & $\begin{array}{c}\text { Compound Amount } \\
\text { Factor }\end{array}$ & \begin{tabular}{|c|}
$\begin{array}{c}\text { Present Worth } \\
\text { Factor }\end{array}$ \\
\end{tabular} & $\begin{array}{c}\text { Compound Amount } \\
\text { Factor }\end{array}$ & Sinting Fund Factor & \begin{tabular}{|c|}
$\begin{array}{c}\text { Present Worth } \\
\text { Factor }\end{array}$ \\
\end{tabular} & $\begin{array}{c}\begin{array}{c}\text { Capital Recovery } \\
\text { Factor }\end{array} \\
\end{array}$ \\
\hline n & $\begin{array}{c}\text { To find } F \text { when given } \\
\text { a } \\
(F / P, i, n) \\
\end{array}$ & $\begin{array}{c}\text { To find } \mathrm{P} \text { when given } \\
\text { an } \mathrm{F} \\
(\mathrm{P} / \mathrm{F}, \mathrm{i}, \mathrm{n})\end{array}$ & $\begin{array}{c}\text { To find } F \text { when given } \\
\text { an } A \\
(F / A, i, n) \\
\end{array}$ & $\begin{array}{c}\text { To find } A \text { when given } \\
\text { an } F \\
(A \sqrt{F}, \mathrm{i}, \mathrm{n}) \\
\end{array}$ & $\begin{array}{c}\text { To find } P \text { when given } \\
\text { an } A \\
(P / A, i, n)\end{array}$ & $\begin{array}{c}\text { To find } A \text { when given } \\
\text { aP } \\
(A / P, i, n)\end{array}$ \\
\hline 1 & 1.1800 & 0.8475 & 1.0000 & 1.0000 & 0.8475 & 1.1800 \\
\hline 2 & 1.3924 & 0.7182 & 2.1800 & 0.4587 & 1.5656 & 0.6387 \\
\hline 3 & 1.6430 & 0.6086 & 3.5724 & 0.2799 & 2.1743 & 0.4599 \\
\hline 4 & 1.9388 & 0.5158 & 5.2154 & 0.1917 & 2.6901 & 0.3717 \\
\hline 5 & 2.2878 & 0.4371 & 7.1542 & 0.1398 & 3.1272 & 0.3198 \\
\hline 6 & 2.6996 & 0.3704 & 9.4420 & 0.1059 & 3.4976 & 0.2859 \\
\hline 7 & 3.1855 & 0.3139 & 12.1415 & 0.0824 & 3.8115 & 0.2624 \\
\hline 8 & 3.7589 & 0.2660 & 15.3270 & 0.0652 & 4.0776 & 0.2452 \\
\hline 9 & 4.4355 & 0.2255 & 19.0859 & 0.0524 & 4.3030 & 0.2324 \\
\hline 10 & 5.2338 & 0.1911 & 23.5213 & 0.0425 & 4.4941 & 0.2225 \\
\hline 11 & 6.1759 & 0.1619 & 28.7551 & 0.0348 & 4.6560 & 0.2148 \\
\hline 12 & 7.2876 & 0.1372 & 34.9311 & 0.0286 & 4.7932 & 0.2086 \\
\hline 13 & 8.5994 & 0.1163 & 42.2187 & 0.0237 & 4.9095 & 0.2037 \\
\hline 14 & 10.1472 & 0.0985 & 50.8180 & 0.0197 & 5.0081 & 0.1997 \\
\hline 15 & 11.9737 & 0.0835 & 60.9653 & 0.0164 & 5.0916 & 0.1964 \\
\hline 16 & 14.1290 & 0.0708 & 72.9390 & 0.0137 & 5.1624 & 0.1937 \\
\hline 17 & 16.6722 & 0.0600 & 87.0680 & 0.0115 & 5.2223 & 0.1915 \\
\hline 18 & 19.6733 & 0.0508 & 103.7403 & 0.0096 & 5.2732 & 0.1896 \\
\hline 19 & 23.2144 & 0.0431 & 123.4135 & 0.0081 & 5.3162 & 0.1881 \\
\hline 20 & 27.3930 & 0.0365 & 146.6280 & 0.0068 & 5.3527 & 0.1868 \\
\hline 21 & 32.3238 & 0.0309 & 174.0210 & 0.0057 & 5.3837 & 0.1857 \\
\hline 22 & 38.1421 & 0.0262 & 206.3448 & 0.0048 & 5.4099 & 0.1848 \\
\hline 23 & 45.0076 & 0.0222 & 244.4868 & 0.0041 & 5.4321 & 0.1841 \\
\hline 24 & 53.1090 & 0.0188 & 289.4945 & 0.0035 & 5.4509 & 0.1835 \\
\hline 25 & 62.6686 & 0.0160 & 342.6035 & 0.0029 & 5.4669 & 0.1829 \\
\hline 26 & 73.9490 & 0.0135 & 405.2721 & 0.0025 & 5.4804 & 0.1825 \\
\hline 27 & 87.2598 & 0.0115 & 479.2211 & 0.0021 & 5.4919 & 0.1821 \\
\hline 28 & 102.9666 & 0.0097 & 566.4809 & 0.0018 & 5.5016 & 0.1818 \\
\hline 29 & 121.5005 & 0.0082 & 669.4475 & 0.0015 & 5.5098 & 0.1815 \\
\hline 30 & 143.3706 & 0.0070 & 790.9480 & 0.0013 & 5.5168 & 0.1813 \\
\hline 31 & 169.1774 & 0.0059 & 934.3186 & 0.0011 & 5.5227 & 0.1811 \\
\hline 32 & 199.6293 & 0.0050 & 1103.4960 & 0.0009 & 5.5277 & 0.1809 \\
\hline 33 & 235.5625 & 0.0042 & 1303.1253 & 0.0008 & 5.5320 & 0.1808 \\
\hline 34 & 277.9638 & 0.0036 & 1538.6878 & 0.0006 & 5.5356 & 0.1806 \\
\hline 35 & 327.9973 & 0.0030 & 1816.6516 & 0.0006 & 5.5386 & 0.1806 \\
\hline 36 & 387.0368 & 0.0026 & 2144.6489 & 0.0005 & 5.5412 & 0.1805 \\
\hline 37 & 456.7034 & 0.0022 & 2531.6857 & 0.0004 & 5.5434 & 0.1804 \\
\hline 38 & 538.9100 & 0.0019 & 2988.3891 & 0.0003 & 5.5452 & 0.1803 \\
\hline 39 & 635.9139 & 0.0016 & 3527.2992 & 0.0003 & 5.5468 & 0.1803 \\
\hline 40 & 750.3783 & 0.0013 & 4163.2130 & 0.0002 & 5.5482 & 0.1802 \\
\hline 45 & 1716.6839 & 0.0006 & 9531.5771 & 0.0001 & 5.5523 & 0.1801 \\
\hline 48 & 2820.5665 & 0.0004 & 15664.2586 & 0.0001 & 5.5536 & 0.1801 \\
\hline 50 & 3927.3569 & 0.0003 & 21813.0937 & 0.0000 & 5.5541 & 0.1800 \\
\hline 54 & 7614.2721 & 0.0001 & 42295.9563 & 0.0000 & 5.5548 & 0.1800 \\
\hline 60 & 20555.1400 & 0.0000 & 114189.6665 & 0.0000 & 5.5553 & 0.1800 \\
\hline
\end{tabular}


Compound Intereste Table for: $\mathrm{i}=\mathbf{2 0} \%$

\begin{tabular}{|c|c|c|c|c|c|c|}
\hline & \multicolumn{2}{|c|}{ Single Payment } & \multicolumn{4}{|c|}{ Uniform Series } \\
\hline & $\begin{array}{l}\text { Compound Amount } \\
\text { Factor }\end{array}$ & $\begin{array}{l}\text { Present Worth } \\
\text { Factor }\end{array}$ & $\begin{array}{c}\text { Compound Amount } \\
\text { Factor }\end{array}$ & Sinking Fund Factor & $\begin{array}{l}\text { Present Worth } \\
\text { Factor }\end{array}$ & $\begin{array}{c}\text { Capital Recovery } \\
\text { Factor }\end{array}$ \\
\hline $\mathbf{n}$ & $\begin{array}{c}\text { To find } F \text { when given } \\
\text { a P } \\
(F / P, i, n)\end{array}$ & $\begin{array}{c}\text { To find } P \text { when given } \\
\text { an } F \\
(P / F, i, n)\end{array}$ & $\begin{array}{c}\text { To find } \mathrm{F} \text { when given } \\
\text { an } \mathrm{A} \\
\text { (F/A, } \mathrm{i}, \mathrm{n})\end{array}$ & $\begin{array}{c}\text { To find } A \text { when given } \\
\text { an } F \\
(A / F, i, n)\end{array}$ & $\begin{array}{c}\text { To find } P \text { when given } \\
\text { an } A \\
\text { (P/A, i, n) }\end{array}$ & $\begin{array}{c}\text { To find } A \text { when given } \\
\text { a } P \\
\text { (AVP,i, n) }\end{array}$ \\
\hline 1 & 1.2000 & 0.8333 & 1.0000 & 1.0000 & 0.8333 & 1.2000 \\
\hline 2 & 1.4400 & 0.6944 & 2.2000 & 0.4545 & 1.5278 & 0.6545 \\
\hline 3 & 1.7280 & 0.5787 & 3.6400 & 0.2747 & 2.1065 & 0.4747 \\
\hline 4 & 2.0736 & 0.4823 & 5.3680 & 0.1863 & 2.5887 & 0.3863 \\
\hline 5 & 2.4883 & 0.4019 & 7.4416 & 0.1344 & 2.9906 & 0.3344 \\
\hline 6 & 2.9860 & 0.3349 & 9.9299 & 0.1007 & 3.3255 & 0.3007 \\
\hline 7 & $\mathbf{3 . 5 8 3 2}$ & 0.2791 & 12.9159 & 0.0774 & 3.6046 & 0.2774 \\
\hline 8 & 4.2998 & 0.2326 & 16.4991 & 0.0606 & 3.8372 & 0.2606 \\
\hline 9 & 5.1598 & 0.1938 & 20.7989 & 0.0481 & 4.0310 & 0.2481 \\
\hline 10 & 6.1917 & 0.1615 & 25.9587 & 0.0385 & 4.1925 & 0.2385 \\
\hline 11 & 7.4301 & 0.1346 & 32.1504 & 0.0311 & 4.3271 & 0.2311 \\
\hline 12 & 8.9161 & 0.1122 & 39.5805 & 0.0253 & 4.4392 & 0.2253 \\
\hline 13 & 10.6993 & 0.0935 & 48.4966 & 0.0206 & 4.5327 & 0.2206 \\
\hline 14 & 12.8392 & 0.0779 & 59.1959 & 0.0169 & 4.6106 & 0.2169 \\
\hline 15 & 15.4070 & 0.0649 & 72.0351 & 0.0139 & 4.6755 & 0.2139 \\
\hline 16 & 18.4884 & 0.0541 & 87.4421 & 0.0114 & 4.7296 & 0.2114 \\
\hline 17 & 22.1861 & 0.0451 & 105.9306 & 0.0094 & 4.7746 & 0.2094 \\
\hline 18 & 26.6233 & 0.0376 & 128.1167 & 0.0078 & 4.8122 & 0.2078 \\
\hline 19 & 31.9480 & 0.0313 & 154.7400 & 0.0065 & 4.8435 & 0.2065 \\
\hline 20 & 38.3376 & 0.0261 & 186.6880 & 0.0054 & 4.8696 & 0.2054 \\
\hline 21 & 46.0051 & 0.0217 & 225.0256 & 0.0044 & 4.8913 & 0.2044 \\
\hline 22 & 55.2061 & 0.0181 & 271.0307 & 0.0037 & 4.9094 & 0.2037 \\
\hline 23 & 66.2474 & 0.0151 & 326.2369 & 0.0031 & 4.9245 & 0.2031 \\
\hline 24 & 79.4968 & 0.0126 & 392.4842 & 0.0025 & 4.9371 & 0.2025 \\
\hline 25 & 95.3962 & 0.0105 & 471.9811 & 0.0021 & 4.9476 & 0.2021 \\
\hline 26 & 114.4755 & 0.0087 & 567.3773 & 0.0018 & 4.9563 & 0.2018 \\
\hline 27 & 137.3706 & 0.0073 & 681.8528 & 0.0015 & 4.9636 & 0.2015 \\
\hline 28 & 164.8447 & 0.0061 & 819.2233 & 0.0012 & 4.9697 & 0.2012 \\
\hline 29 & 197.8136 & 0.0051 & 984.0680 & 0.0010 & 4.9747 & 0.2010 \\
\hline 30 & 237.3763 & 0.0042 & 1181.8816 & 0.0008 & 4.9789 & 0.2008 \\
\hline 31 & 284.8516 & 0.0035 & 1419.2579 & 0.0007 & 4.9824 & 0.2007 \\
\hline 32 & 341.8219 & 0.0029 & 1704.1095 & 0.0006 & 4.9854 & 0.2006 \\
\hline 33 & 410.1863 & 0.0024 & 2045.9314 & 0.0005 & 4.9878 & 0.2005 \\
\hline 34 & 492.2235 & 0.0020 & 2456.1176 & 0.0004 & 4.9898 & 0.2004 \\
\hline 35 & 590.6682 & 0.0017 & 2948.3411 & 0.0003 & 4.9915 & 0.2003 \\
\hline 36 & 708.8019 & 0.0014 & 3539.0094 & 0.0003 & 4.9929 & 0.2003 \\
\hline 37 & 850.5622 & 0.0012 & 4247.8112 & 0.0002 & 4.9941 & 0.2002 \\
\hline 38 & 1020.6747 & 0.0010 & 5098.3735 & 0.0002 & 4.9951 & 0.2002 \\
\hline 39 & 1224.8096 & 0.0008 & 6119.0482 & 0.0002 & 4.9959 & 0.2002 \\
\hline 40 & 1469.7716 & 0.0007 & 7343.8578 & 0.0001 & 4.9966 & 0.2001 \\
\hline 45 & 3657.2620 & 0.0003 & 18281.3099 & 0.0001 & 4.9986 & 0.2001 \\
\hline 48 & 6319.7487 & 0.0002 & 31593.7436 & 0.0000 & 4.9992 & 0.2000 \\
\hline 50 & 9100.4382 & 0.0001 & 45497.1908 & 0.0000 & 4.9995 & 0.2000 \\
\hline 54 & 18870.6685 & 0.0001 & 94348.3427 & 0.0000 & 4.9997 & 0.2000 \\
\hline 60 & 56347.5144 & 0.0000 & 281732.5718 & 0.0000 & 4.9999 & 0.2000 \\
\hline
\end{tabular}


Compound Intereste Table for: $\mathbf{i}=\mathbf{2 5 \%}$

\begin{tabular}{|c|c|c|c|c|c|c|}
\hline & \multicolumn{2}{|c|}{ Single Payment } & \multicolumn{4}{|c|}{ Lhiform Series } \\
\hline & $\begin{array}{c}\text { Compound Amount } \\
\text { Factor }\end{array}$ & $\begin{array}{c}\begin{array}{c}\text { Present Worth } \\
\text { Factor }\end{array} \\
\end{array}$ & $\begin{array}{c}\text { Compound Amount } \\
\text { Factor }\end{array}$ & Sinking Fund Factor & $\begin{array}{c}\begin{array}{c}\text { Present Worth } \\
\text { Factor }\end{array} \\
\end{array}$ & $\begin{array}{c}\begin{array}{c}\text { Capital Recovery } \\
\text { Factor }\end{array} \\
\end{array}$ \\
\hline $\mathbf{n}$ & $\begin{array}{c}\text { To find } F \text { when given } \\
\text { a } P \\
(F / P, i, n)\end{array}$ & $\begin{array}{c}\text { To find } P \text { when given } \\
\text { an } F \\
(P / F, i, n)\end{array}$ & $\begin{array}{c}\text { To find } F \text { when given } \\
\text { an } A \\
(F / A, i, n)\end{array}$ & $\begin{array}{c}\text { To find } A \text { when given } \\
\text { an } F \\
\text { (A/F, } i, n)\end{array}$ & $\begin{array}{c}\text { To find } P \text { when given } \\
\text { an } A \\
(P / A, i, n)\end{array}$ & $\begin{array}{c}\text { To find } A \text { when giver } \\
\text { a P } \\
\text { (AVP, } \mathrm{i}, \mathrm{n} \text { ) }\end{array}$ \\
\hline 1 & 1.2500 & 0.8000 & 1.0000 & 1.0000 & 0.8000 & 1.2500 \\
\hline 2 & 1.5625 & 0.6400 & 2.2500 & 0.4444 & 1.4400 & 0.6944 \\
\hline 3 & 1.9531 & 0.5120 & 3.8125 & 0.2623 & 1.9520 & 0.5123 \\
\hline 4 & 2.4414 & 0.4096 & 5.7656 & 0.1734 & 2.3616 & 0.4234 \\
\hline 5 & 3.0518 & 0.3277 & 8.2070 & 0.1218 & 2.6893 & 0.3718 \\
\hline 6 & 3.8147 & 0.2621 & 11.2588 & 0.0888 & 2.9514 & 0.3388 \\
\hline 7 & 4.7684 & 0.2097 & 15.0735 & 0.0663 & 3.1611 & 0.3163 \\
\hline 8 & 5.9605 & 0.1678 & 19.8419 & 0.0504 & 3.3289 & 0.3004 \\
\hline 9 & 7.4506 & 0.1342 & 25.8023 & 0.0388 & 3.4631 & 0.2888 \\
\hline 10 & 9.3132 & 0.1074 & 33.2529 & 0.0301 & 3.5705 & 0.2801 \\
\hline 11 & 11.6415 & 0.0859 & 42.5661 & 0.0235 & 3.6564 & 0.2735 \\
\hline 12 & 14.5519 & 0.0687 & 54.2077 & 0.0184 & 3.7251 & 0.2684 \\
\hline 13 & 18.1899 & 0.0550 & 68.7596 & 0.0145 & 3.7801 & 0.2645 \\
\hline 14 & 22.7374 & 0.0440 & 86.9495 & 0.0115 & 3.8241 & 0.2615 \\
\hline 15 & 28.4217 & 0.0352 & 109.6868 & 0.0091 & 3.8593 & 0.2591 \\
\hline 16 & 35.5271 & 0.0281 & 138.1085 & 0.0072 & 3.8874 & 0.2572 \\
\hline 17 & 44.4089 & 0.0225 & 173.6357 & 0.0058 & 3.9099 & 0.2558 \\
\hline 18 & 55.5112 & 0.0180 & 218.0446 & 0.0046 & 3.9279 & 0.2546 \\
\hline 19 & 69.3889 & 0.0144 & 273.5558 & 0.0037 & 3.9424 & 0.2537 \\
\hline 20 & 86.7362 & 0.0115 & 342.9447 & 0.0029 & 3.9539 & 0.2529 \\
\hline 21 & 108.4202 & 0.0092 & 429.6809 & 0.0023 & 3.9631 & 0.2523 \\
\hline 22 & 135.5253 & 0.0074 & 538.1011 & 0.0019 & 3.9705 & 0.2519 \\
\hline 23 & 169.4066 & 0.0059 & 673.6264 & 0.0015 & 3.9764 & 0.2515 \\
\hline 24 & 211.7582 & 0.0047 & 843.0329 & 0.0012 & 3.9811 & 0.2512 \\
\hline 25 & 264.6978 & 0.0038 & 1054.7912 & 0.0009 & 3.9849 & 0.2509 \\
\hline 26 & 330.8722 & 0.0030 & 1319.4890 & 0.0008 & 3.9879 & 0.2508 \\
\hline 27 & 413.5903 & 0.0024 & 1650.3612 & 0.0006 & 3.9903 & 0.2506 \\
\hline 28 & 516.9879 & 0.0019 & 2063.9515 & 0.0005 & 3.9923 & 0.2505 \\
\hline 29 & 646.2349 & 0.0015 & 2580.9394 & 0.0004 & 3.9938 & 0.2504 \\
\hline 30 & 807.7936 & 0.0012 & 3227.1743 & 0.0003 & 3.9950 & 0.2503 \\
\hline 31 & 1009.7420 & 0.0010 & 4034.9678 & 0.0002 & 3.9960 & 0.2502 \\
\hline 32 & 1262.1774 & 0.0008 & 5044.7098 & 0.0002 & 3.9968 & 0.2502 \\
\hline 33 & 1577.7218 & 0.0006 & 6306.8872 & 0.0002 & 3.9975 & 0.2502 \\
\hline 34 & 1972.1523 & 0.0005 & 7884.6091 & 0.0001 & 3.9980 & 0.2501 \\
\hline 35 & 2465.1903 & 0.0004 & 9856.7613 & 0.0001 & 3.9984 & 0.2501 \\
\hline 36 & 3081.4879 & 0.0003 & 12321.9516 & 0.0001 & 3.9987 & 0.2501 \\
\hline 37 & 3851.8599 & 0.0003 & 15403.4396 & 0.0001 & 3.9990 & 0.2501 \\
\hline 38 & 4814.8249 & 0.0002 & 19255.2994 & 0.0001 & 3.9992 & 0.2501 \\
\hline 39 & 6018.5311 & 0.0002 & 24070.1243 & 0.0000 & 3.9993 & 0.2500 \\
\hline 40 & 7523.1638 & 0.0001 & 30088.6554 & 0.0000 & 3.9995 & 0.2500 \\
\hline 45 & 22958.8740 & 0.0000 & 91831.4962 & 0.0000 & 3.9998 & 0.2500 \\
\hline 48 & 44841.5509 & 0.0000 & 179362.2034 & 0.0000 & 3.9999 & 0.2500 \\
\hline 50 & 70064.9232 & 0.0000 & 280255.6929 & 0.0000 & 3.9999 & 0.2500 \\
\hline 54 & 171056.9414 & 0.0000 & 684223.7658 & 0.0000 & 4.0000 & 0.2500 \\
\hline 60 & 652530.4468 & 0.0000 & 2610117.7872 & 0.0000 & 4.0000 & 0.2500 \\
\hline
\end{tabular}




\section{Compound Intereste Table for: $\mathrm{i}=\mathbf{3 0} \%$}

\begin{tabular}{|c|c|c|c|c|c|c|}
\hline & \multicolumn{2}{|c|}{ Single Payment } & \multicolumn{4}{|c|}{ Uniform Series } \\
\hline & $\begin{array}{l}\text { Compound Amount } \\
\text { Factor }\end{array}$ & $\begin{array}{c}\text { Present Worth } \\
\text { Factor }\end{array}$ & $\begin{array}{c}\text { Compound Amount } \\
\text { Factor }\end{array}$ & Sinking Fund Factor & $\begin{array}{c}\text { Present Worth } \\
\text { Factor }\end{array}$ & $\begin{array}{l}\text { Capital Recovery } \\
\text { Factor }\end{array}$ \\
\hline n & $\begin{array}{c}\text { To find } F \text { when given } \\
\text { a } \mathrm{P} \\
(\mathrm{F} / \mathrm{P}, \mathrm{i}, \mathrm{n})\end{array}$ & $\begin{array}{c}\text { To find } P \text { when given } \\
\text { an } F \\
(P / F, i, n)\end{array}$ & $\begin{array}{c}\text { To find } F \text { when given } \\
\text { an } A \\
\text { (F/A, } \mathrm{i}, \mathrm{n})\end{array}$ & $\begin{array}{c}\text { To find } A \text { when given } \\
\text { an } F \\
\text { (AVF, i, n) }\end{array}$ & $\begin{array}{c}\text { To find } P \text { when given } \\
\text { an } A \\
(P / A, i, n)\end{array}$ & $\begin{array}{c}\text { To find } A \text { when given } \\
\text { aP } \\
\text { (A/P, } i, n)\end{array}$ \\
\hline 1 & 1.3000 & 0.7692 & 1.0000 & 1.0000 & 0.7692 & 1.3000 \\
\hline 2 & 1.6900 & 0.5917 & 2.3000 & 0.4348 & 1.3609 & 0.7348 \\
\hline 3 & 2.1970 & 0.4552 & 3.9900 & 0.2506 & 1.8161 & 0.5506 \\
\hline 4 & 2.8561 & 0.3501 & 6.1870 & 0.1616 & 2.1662 & 0.4616 \\
\hline 5 & 3.7129 & 0.2693 & 9.0431 & 0.1106 & 2.4356 & 0.4106 \\
\hline 6 & 4.8268 & 0.2072 & 12.7560 & 0.0784 & 2.6427 & 0.3784 \\
\hline 7 & 6.2749 & 0.1594 & 17.5828 & 0.0569 & 2.8021 & 0.3569 \\
\hline 8 & 8.1573 & 0.1226 & 23.8577 & 0.0419 & 2.9247 & 0.3419 \\
\hline 9 & 10.6045 & 0.0943 & 32.0150 & 0.0312 & 3.0190 & 0.3312 \\
\hline 10 & 13.7858 & 0.0725 & 42.6195 & 0.0235 & 3.0915 & 0.3235 \\
\hline 11 & 17.9216 & 0.0558 & 56.4053 & 0.0177 & 3.1473 & 0.3177 \\
\hline 12 & 23.2981 & 0.0429 & 74.3270 & 0.0135 & 3.1903 & 0.3135 \\
\hline 13 & 30.2875 & 0.0330 & 97.6250 & 0.0102 & 3.2233 & 0.3102 \\
\hline 14 & 39.3738 & 0.0254 & 127.9125 & 0.0078 & 3.2487 & 0.3078 \\
\hline 15 & 51.1859 & 0.0195 & 167.2863 & 0.0060 & 3.2682 & 0.3060 \\
\hline 16 & 66.5417 & 0.0150 & 218.4722 & 0.0046 & 3.2832 & 0.3046 \\
\hline 17 & 86.5042 & 0.0116 & 285.0139 & 0.0035 & 3.2948 & 0.3035 \\
\hline 18 & 112.4554 & 0.0089 & 371.5180 & 0.0027 & 3.3037 & 0.3027 \\
\hline 19 & 146.1920 & 0.0068 & 483.9734 & 0.0021 & 3.3105 & 0.3021 \\
\hline 20 & 190.0496 & 0.0053 & 630.1655 & 0.0016 & 3.3158 & 0.3016 \\
\hline 21 & 247.0645 & 0.0040 & 820.2151 & 0.0012 & 3.3198 & 0.3012 \\
\hline 22 & 321.1839 & 0.0031 & 1067.2796 & 0.0009 & 3.3230 & 0.3009 \\
\hline 23 & 417.5391 & 0.0024 & 1388.4535 & 0.0007 & 3.3254 & 0.3007 \\
\hline 24 & 542.8008 & 0.0018 & 1806.0026 & 0.0006 & 3.3272 & 0.3006 \\
\hline 25 & 705.6410 & 0.0014 & 2348.8033 & 0.0004 & 3.3286 & 0.3004 \\
\hline 26 & 917.3333 & 0.0011 & 3054.4443 & 0.0003 & 3.3297 & 0.3003 \\
\hline 27 & 1192.5333 & 0.0008 & 3971.7776 & 0.0003 & 3.3305 & 0.3003 \\
\hline 28 & 1550.2933 & 0.0006 & 5164.3109 & 0.0002 & 3.3312 & 0.3002 \\
\hline 29 & 2015.3813 & 0.0005 & 6714.6042 & 0.0001 & 3.3317 & 0.3001 \\
\hline 30 & 2619.9956 & 0.0004 & 8729.9855 & 0.0001 & 3.3321 & 0.3001 \\
\hline 31 & 3405.9943 & 0.0003 & 11349.9811 & 0.0001 & 3.3324 & 0.3001 \\
\hline 32 & 4427.7926 & 0.0002 & 14755.9755 & 0.0001 & 3.3326 & 0.3001 \\
\hline 33 & 5756.1304 & 0.0002 & 19183.7681 & 0.0001 & 3.3328 & 0.3001 \\
\hline 34 & 7482.9696 & 0.0001 & 24939.8985 & 0.0000 & 3.3329 & 0.3000 \\
\hline 35 & 9727.8604 & 0.0001 & 32422.8681 & 0.0000 & 3.3330 & 0.3000 \\
\hline 36 & 12646.2186 & 0.0001 & 42150.7285 & 0.0000 & 3.3331 & 0.3000 \\
\hline 37 & 16440.0841 & 0.0001 & 54796.9471 & 0.0000 & 3.3331 & 0.3000 \\
\hline 38 & 21372.1094 & 0.0000 & 71237.0312 & 0.0000 & 3.3332 & 0.3000 \\
\hline 39 & 27783.7422 & 0.0000 & 92609.1405 & 0.0000 & 3.3332 & 0.3000 \\
\hline 40 & 36118.8648 & 0.0000 & 120392.8827 & 0.0000 & 3.3332 & 0.3000 \\
\hline 45 & 134106.8167 & 0.0000 & 447019.3890 & 0.0000 & 3.3333 & 0.3000 \\
\hline 48 & 294632.6763 & 0.0000 & 982105.5877 & 0.0000 & 3.3333 & 0.3000 \\
\hline 50 & 497929.2230 & 0.0000 & 1659760.7433 & 0.0000 & 3.3333 & 0.3000 \\
\hline 54 & 1422135.6538 & 0.0000 & 4740448.8458 & 0.0000 & 3.3333 & 0.3000 \\
\hline 60 & 6864377.1727 & 0.0000 & 22881253.9091 & 0.0000 & 3.3333 & 0.3000 \\
\hline
\end{tabular}

